Notre Dame Law School

NDLScholarship

Journal Articles

Publications

2007

\title{
Neuroimaging and the "Complexity" of Capital Punishment
}

O. Carter Snead

Notre Dame Law School, snead.1@nd.edu

Follow this and additional works at: https://scholarship.law.nd.edu/law_faculty_scholarship

Part of the Criminal Law Commons, Criminal Procedure Commons, and the Legal Ethics and Professional Responsibility Commons

\section{Recommended Citation}

O. C. Snead, Neuroimaging and the "Complexity" of Capital Punishment, 82 N.Y.U. L. Rev. 1265 (2007).

Available at: https://scholarship.law.nd.edu/law_faculty_scholarship/542

This Article is brought to you for free and open access by the Publications at NDLScholarship. It has been accepted for inclusion in Journal Articles by an authorized administrator of NDLScholarship. For more information, please contact lawdr@nd.edu. 


\title{
ARTICLES
}

\section{NEUROIMAGING AND THE "COMPLEXITY" OF CAPITAL PUNISHMENT}

\author{
O. Carter Snead*
}

The growing use of brain imaging technology to explore the causes of morally, socially, and legally relevant behavior is the subject of much discussion and controversy in both scholarly and popular circles. From the efforts of cognitive neuroscientists in the courtroom and the public square, the contours of a project to transform capital sentencing both in principle and in practice have emerged. In the short term, these scientists seek to play a role in the process of capital sentencing by serving as mitigation experts for defendants, invoking neuroimaging research on the roots of criminal violence to support their arguments. Over the long term, these same experts (and their like-minded colleagues) hope to appeal to the recent findings of their discipline to embarrass, discredit, and ultimately overthrow retributive justice as a principle of punishment. Taken as a whole, these short-and long-term efforts are ultimately meant to usher in a more compassionate and humane regime for capital defendants.

This Article seeks to articulate, analyze, and provide a critique of this project according to the metric of its own humanitarian aspirations. It proceeds by exploring the implications of the project in light of the mechanics of capital sentencing and the heterogeneous array of competing doctrinal rationales in which they are rooted. The Article concludes that the project as currently conceived is internally inconsistent and would, if implemented, result in ironic and tragic consequences, producing a death penalty regime that is even more draconian and less humane than the deeply flawed framework currently in place.

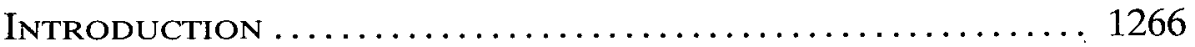

I. The Era of Cognitive Neuroscience ............ 1273

A. Cognitive Neuroscience: Its Object and Premises ... 1273 1. What is Cognitive Neuroscience? ............ 1273

2. Cognitive Neuroscience: The Grounding Premise ............................. 1277

B. Neuroimaging: A Window into the Mind? ........ 1280

* Copyright (c) 2007 by O. Carter Snead, Associate Professor, Notre Dame Law School. Many thanks to Hank Greely, Judy Illes, Mike Gazzaniga, Jeffrey Rosen, Carl Elliott, Steve Goldberg, Larry Gostin, Jonathan Moreno, Josh Greene, John Finnis, Rick Garnett, Nicole Garnett, Tricia Bellia, John Nagle, Amy Barrett, Mike Jenuwine, Mike Kirsch, Gerry Bradley, John Robinson, Bob Rodes, Leigh Fitzpatrick Snead, John Ritsick, Adam Schulman, Leon Kass, Yuval Levin, Eric Cohen, Bill Hurlbut, Mark Frankel, and the American Association for the Advancement of Science. Thanks also to the faculty participants at the University of Illinois Faculty Workshop and the Quinnipiac University Health Law Speakers Series. Erin Groeber, Lee Roach, Lauren Galgano, Patti Ogden, Warren Rees, Dwight King, and Peter Ladwein provided invaluable research and editorial support. 
1. Anatomical Techniques................... 1281

2. Functional Techniques .................... 1282

3. Potential Difficulties .................. 1286

C. Neuroimaging and the Law Generally............ 1290

D. Neurological Bases of Criminal Violence .......... 1293

1. Psychopathy and Antisocial Personality

Disorder ................................. 1296

II. The Aspirations of Cognitive Neuroscience for Capital Sentencing........................... 1299

A. Short-Term Aim: Aiding Capital Defendants....... 1299

B. Long-Term Aim: The Overthrow of Retribution .... 1308

III. A Critique of the Aspirations of Cognitive

Neuroscience: The Complexity of Punishment ... 1318

A. The Short-Term Aspiration: Mitigation and Just

Deserts .................................. 1319

B. The Long-Term Aspiration: Prediction and

Prevention ................................ 1322

C. The Marriage of Dr. Grigson and Lady Wootton ... 1328

D. Objections and Responses ................... 1334

Conclusion ......................................... 1338

Till we have developed this sense of the complexity of punishment ... we shall be in no fit state to assess the extent to which the whole institution has been eroded by, or needs to be adapted to, new beliefs about the human mind. ${ }^{1}$

- H.L.A. Hart

\section{INTRODUCTION}

"Can brain scans be used to determine whether a person is inclined toward criminality or violent behavior?"2 This question, asked by Senator Joseph Biden of Delaware at the hearing considering the nomination of John Roberts to be Chief Justice of the United States, illustrates the extent to which cognitive neuros-

1 H.L.A. Hart, Punishment and Responsibility 3 (1968).

2 Confirmation Hearing on the Nomination of John G. Roberts, Jr., to be Chief Justice of the United States: Hearing Before the S. Comm. on the Judiciary, 109th Cong. 18 (2005) (statement of Sen. Joseph R. Biden, Jr., Member, S. Comm. on the Judiciary). Senator Biden may have been influenced by a contemporaneous article in the New York Times Magazine speculating about the issues that might come before the Supreme Court in the years to come, including "brain scanning to identify criminal suspects." Jeffrey Rosen, Roberts v. the Future, N.Y. Times, Aug. 28, 2005, § 6 (Magazine), at 24. 
cience ${ }^{3}$-increasingly augmented by the growing powers of neuroimaging 4 -has captured the imagination of those who make, enforce, interpret, and study the law. Judges, both state and federal, have convened conferences to discuss the legal ramifications of developments in cognitive neuroscience. 5 Scholarly volumes have been devoted to the subject. ${ }^{6}$ The President's Council on Bioethics convened several sessions to discuss cognitive neuroscience and its potential impact on theories of moral and legal responsibility. ${ }^{7}$ The United States General Accounting Office drafted a report surveying the views of government officials representing the CIA, Department of Defense, Secret Service, and FBI on the potential uses of "brain fingerprinting," a lie detection technique that utilizes functional neuroimaging. ${ }^{8}$ More recently, civil libertarians have expressed suspicion and concern that the United States government is using various

3 Cognitive neuroscience can be described as the science of how the brain enables the mind. See, e.g., Michael S. Gazzaniga, The Mind's Past xii (1998) ("How the brain enables mind is the question to be answered in the twenty-first century ....").

4 For an overview of neuroimaging techniques, including computed tomography (CT) scanning, magnetic resonance imaging (MRI), electroencephalography (EEG), positron emission tomography (PET), single-photon emission computed tomography (SPECT), and functional magnetic resonance imaging (fMRI), see infra Part I.B.

5 In June 2006, the American Academy for the Advancement of Science, the Federal Judicial Center, the Dana Foundation, and the National Center for State Courts cosponsored the Judicial Seminar on Emerging Neuroscience Issues. The conference agenda and presentations are available at NCSC: Research - Science, Technology and the Law, http:// www.ncsconline.org/d_research/stl/conferences-aaas.html (last visited Aug. 19, 2007). See also Caryn Tamber, Brave Neuro World, Dally Rec. (Balt.), Dec. 30, 2005, at 1 (describing educational program for Maryland judges to increase understanding of neuroimaging evidence).

6 E.g., Neuroscience and the Law (Brent Garland ed., 2004); The Measurement of Brain Activity, 354 Phil. Transactions Royal Soc'y: Biological Sci. 1119 (1999) (compiling works studying neuroimaging and other brain activity measures as themed issue); Symposium, The Mind of a Child: The Relationship Between Brain Development, Cognitive Functioning, and Accountability Under the Law, 3 Oноо ST. J. CRiм. L. 317 (2006); see also The New Neuromorality, http://www.aei.org/events/eventID.1072,filter.all/ event_detail.asp (last visited Aug. 19, 2007) (providing video and materials from June 1, 2005, American Enterprise Institute conference panel entitled "Legal and Moral Implications of the New Neuroscience," moderated by Christina Hoff Sommers with panelists Joshua D. Greene, Stephen J. Morse, and Steven Pinker).

7 President's Council on Bioethics, Transcripts (April 1, 2004), http://www.bioethics. gov/transcripts/april04/april1.html; President's Council on Bioethics, Transcripts (June 25, 2004), http://www.bioethics.gov/transcripts/june04/june25.html.

8 U.S. Gen. Accounting Office, Investigative Techniques: Federal Agency Views on the Potential Application of "Brain Fingerprinting" (2001). The report concluded that federal law enforcement agencies did not foresee the use of "brain fingerprinting" given its limited applications and high cost. Id. at 8-10. For a discussion of evidentiary questions arising from the use of both "brain fingerprinting" and related fMRIbased lie detection techniques in the courtroom, see generally Charles N.W. Keckler, Cross-Examining the Brain: A Legal Analysis of Neural Imaging for Credibility Impeachment, 57 Hastings L.J. 509 (2006). 
neuroimaging techniques in the war on terrorism..$^{9}$ Members of the personal injury bar have urged the use of functional neuroimaging to make "mild to moderate brain [and nervous] injuries ... visible [to] jurors." 10 Not surprisingly, members of the civil defense bar have published articles criticizing the reliability of such evidence and arguing that it should be inadmissible. ${ }^{11}$ Criminal defense attorneys have likewise expressed a strong interest in using neuroimaging evidence to help their clients. ${ }^{12}$

The attraction of the legal community to cognitive neuroscience is by no means unreciprocated. Cognitive neuroscientists have expressed profound interest in how their discipline might impact the law. Michael Gazzaniga, who coined the term "cognitive neuroscience,"13 recently predicted that someday advances in neuroscience will "dominate the entire legal system." 14

Practitioners of cognitive neuroscience seem particularly drawn to the criminal law; 15 more specifically, they have evinced an interest in the death penalty. Indeed, a well-formed cognitive neuroscience project to reform capital sentencing has emerged from their work in the courtroom and their arguments in the public square.

This Article seeks to identify, articulate, take seriously, and provide a critique of this project in light of its own objectives. In Part I, it sets forth a brief introductory discussion of cognitive neuroscience

9 See Press Release, Am. Civil Liberties Union, ACLU Seeks Information About Government Use of Brain Scanners in Interrogations (June 28, 2006), available at http:// www.aclu.org/privacy/medical/26035prs20060628.html (describing request submitted under Freedom of Information Act to all "primary American security agencies" seeking information about use of "cutting-edge brain-scanning technologies on suspected terrorists being held overseas or at home"); see also Jennifer Wild, Brain Imaging Ready To Detect Terrorists, Say Neuroscientists, 437 NATURE 457, 457 (2005) (discussing whether fMRI can be effectively used as lie-detection method in criminal investigations).

10 Donald J. Nolan \& Tressa A. Pankovits, High-Tech Proof in Brain Injury Cases, Trial, June 1, 2005, at 27, 27.

11 E.g., J. Bruce Alverson \& Sandra S. Smagac, Brain Mapping: Should This Controversial Evidence Be Excluded?, 48 FED'N INS. CoRP. Couns. Q. 131 (1998); Brickford Y. Brown et al., Are We Out of the Gray Area Yet? Recent Developments in the Use of PET and SPECT Scans to Prove Causation and Injury in Toxic Tort Litigation, http://www. morankikerbrown.com/CM/Articles/Articles67.asp (last visited June 30, 2007).

12 See infra Part I.C (citing and discussing criminal cases in which defense presented neuroimaging evidence).

13 Silvia A. Bunge \& Itamar Kahn, Cognition, Neuroimaging, in The EnCYClopedia of Neuroscience (George Adelman \& Barry H. Smith eds., Elsevier B.V. CD-ROM, 3d ed. 2004).

14 Michael S. Gazzaniga, The Ethical Brain 88 (2005).

15 See, e.g., Robert M. Sapolsky, The Frontal Cortex and the Criminal Justice System, 359 Phil. Transactions Royal Soc'y: Biological SCl., 1787, 1788 (2004) ("Arguably, the most important arena in which a greater knowledge of neuroscience is needed is the criminal justice system."). 
generally, including its anchoring theoretical premise, its most powerful technical adjunct (neuroimaging), and its present and projected impact on the law, broadly understood. In Part II, it contemplates the aspirations of cognitive neuroscientists vis-à-vis capital sentencing, both in the short term and the long term. ${ }^{16}$ The Article notes that in the short term, cognitive neuroscientists seek to assist defendants' mitigation claims by invoking cutting-edge brain imaging research on the neurobiological roots of criminal violence. Neuroimaging experts appeal to such evidence to bolster defendants' claims that, although legally guilty, they do not deserve to die because the abnormal structure and/or function of their brains diminishes their culpability.

Part II.B further describes how, in the long term, cognitive neuroscientists aim to draw upon the tools of their discipline to embarrass, discredit, and ultimately overthrow retribution ${ }^{17}$ as a dis-

16 This Article uses phrases such as "the cognitive neuroscience project" and "the aspirations of cognitive neuroscience for capital sentencing" as administratively convenient shorthand. The phrases refer to the views of a substantial body of eminent neuroscientists and neuroimaging practitioners working in the field of capital sentencing who embrace the aims described in this Article. It is not meant to imply that cognitive neuroscientists as a whole are monolithic in their opinions on this matter. Indeed, they are not, and some have expressed deep reservations about the use of neuroimaging in the courtroom. See, e.g., Mary Beckman, Crime, Culpability, and the Adolescent Brain, 305 SCIENCE 596, 596-99 (2004) (noting that UCLA neuroscientist Paul Thompson suggests it is "damaging" and premature to apply incipient findings in neuroscience to moral and legal societal questions before neuroscience has sufficiently established its relevance to such questions, while UCLA neuroscientist Elizabeth Sowell argues that neuroimaging is not sufficiently advanced to connect behavior to brain structure); Bruce Bower, Teen Brains on Trial: The Science of Neural Development Tangles with the Juvenile Death Penalty, 165 ScI. News 299 , 301 (2004) (noting concerns of Bradley S. Peterson of Columbia College of Physicians and Surgeons and B.J. Casey of Cornell University's Weill Medical College that neuroscience and neuroimaging results are too crude and ambiguous to be applied to legal, social, or political problems); Helen S. Mayberg, Medical-Legal Inferences from Functional Neuroimaging Evidence, 1 Seminars in Cuinical Neuropsychiatry 195, 200 (1996) (arguing that PET and SPECT scans "have no scientifically supportable exculpatory role in assessing or predicting an individual's responsibility in the commission of a crime"); Donald Reeves et al., Limitations of Brain Imaging in Forensic Psychiatry, 31 J. Ам. ACAD. PsychIATRy \& L. 89, 89-90, 95-96 (2003) (expressing worry that use of novel neuroimaging techniques by forensic experts "may mislead a judge and jury" and explaining several ways such evidence can be manipulated or overstated); Nicholas Thompson, My Brain Made Me Do It, Legal AfF., Jan.-Feb. 2006, at 50, 52 (noting Michael Gazzaniga's worries that defendants will try to use new neuroimaging technology to generate exculpatory evidence in criminal context). Nevertheless, it is fair to say that, as a whole, the cognitive neuroscience project encompasses a number of professionals in the field who are working toward common goals for capital sentencing reform.

17 In this Article, "retribution," "retributive justice," and "just deserts" are used interchangeably to denote the concept that punishment should be distributed on the basis of the personal blameworthiness of the offender, in light of relevant mitigating and aggravating factors. See infra Part III.A (discussing Paul Robinson's account of "punishment according to desert"). 
tributive justification ${ }^{18}$ for punishment. The architects of the cognitive neuroscience project regard retribution as the root cause of the brutality and inhumanity of the American criminal justice system, generally, and the institution of capital punishment, in particular. ${ }^{19}$ To replace retribution, they argue for the adoption of a criminal law regime animated solely by the forward-looking (consequentialist) aim of avoiding social harms. This new framework, they hope, will usher in a new era of what some have referred to as "therapeutic justice"20 for capital defendants, which is meant to be both more humane and more compassionate.

Part III offers a "friendly" critique of the cognitive neuroscience project, taken as a whole. That is, the critique will not take its bearings from the concern, raised by some, that the use of neuroimaging in capital sentencing is an indefensible, soft-hearted prescription for "universal neurological exculpation."21 Nor will it argue that the present and projected efforts of neuroscientists in this domain will be simply another chapter in the long and arguably sordid history of the science of "biological criminality." 22 Instead, this Article will analyze the wisdom and soundness of the project according to the metric of the project's own aspirations: pleading for the lives of capital defendants at sentencing and, ultimately, creating a more compassionate and humane sentencing regime. Thus, the critique is "friendly" in that its point of departure is one of sympathy and solidarity with the

18 H.L.A. Hart distinguished the "General Justifying Aim" of punishment from its "distributive" principles. The former constitutes the ultimate legitimating goal of punishment, whereas the latter is a limiting or qualifying principle that informs the scope of liability (i.e., who may be punished) and the amount of punishment that may be meted out. See HART, supra note 1, at 8-13 (applying distinction to retributive justice and concluding that one need not hold retribution as sole justifying aim of punishment in order to accept its limitations on scope and severity of such punishment).

19 See infra Part II.B.

20 E.g., Jana L. Bufkin \& Vickie R. Luttrell, Neuroimaging Studies of Aggressive and Violent Behavior: Current Findings and Implications for Criminology and Criminal Justice, 6 Trauma Violence \& Abuse 176, 186 (2005) ("Justice is typically defined as just deserts. As a result, legal variables with no inherent explanatory worth are summoned to justify less-than-stellar community-level interventions and unproductive institutionalization. In contrast . . . justice conceived in an interdisciplinary program of study is rehabilitation oriented [and] . . . aimed at therapeutic justice.").

21 Ronald Bailey, Bad Brains: How the Supreme Court's Teen Execution Decision Proves Too Much, ReAson MaG., Mar. 23, 2005, http://www.reason.com/news/show/34963. html.

22 In the nineteenth century, Cesare Lombroso, an Italian physician and anthropologist, posited that the human body itself could provide evidence of criminal disposition. See David G. Horn, The Criminal Body: Lombroso and the Anatomy of Devi. ANCE 1-27 (2003) (describing Lombroso's theories). Some of the more unfortunate applications for the use of such biological metrics of criminality are detailed in STEPHEN JAY Gould, The Mismeasure of Man 152-73 (rev. \& expanded ed. 1996). 
humanitarian impulses (and the concerns about the present system of capital punishment) that undergird the cognitive neuroscience project.

Judged by this standard, Part III concludes that, if realized, the cognitive neuroscience project's aspirations for capital sentencing reform would not succeed; to the contrary, the project would likely aggravate the draconian and brutal features of the present capital sentencing regime. This is because the short- and long-term goals of the cognitive neuroscience project are at war with one another. The short-term goal relies on a particular theory of capital mitigation that is entirely dependent upon the retributive principle that the long-term goal finds unintelligible, while the project's long-term aspiration envisions a capital process that is single-mindedly concerned with the prediction and prevention of criminal harms.

However, the extant mechanisms of capital sentencing that are oriented towards these goals-most clearly embodied by the aggravating factor of future dangerousness-are no friend to the capital defendant. Often, a mitigation claim that death is not deserved is the last refuge available to capital defendants confronted with evidence of their future dangerousness. Thus the project's long-term aspiration, by taking such backward-looking arguments off the table, unintentionally transforms the neuroimaging research from evidence supporting mercy to evidence supporting permanent incapacitation. That is, by attacking the legitimacy of the backward-looking lens of just deserts, neuroimaging evidence ends up suggesting that the often intractablebut nonexcusing for purposes of guilt ${ }^{23}$ - biological predisposition to violence should counsel in favor of the ultimate punishment. To support this conclusion, this Article examines the jurisprudence of future dangerousness, exposes the (perhaps counterintuitive) salutary limiting effects of retribution as a distributive principle in the capital context, and briefly reprises the famous debate between H.L.A. Hart and Lady Barbara Wootton on the purposes and nature of criminal law.

Before moving forward, it is necessary to note several caveats about the scope of this Article, as well as the questions that it leaves unaddressed. First, the aim of this Article is to seriously consider the cognitive neuroscience project for capital sentencing on its own terms. Thus, the critique and analysis will assume for the sake of argument that cognitive neuroscience will ultimately acquire the technical

23 The special role of the jury in capital sentencing creates a unique situation in which mental health evidence that is inadmissible during the "guilt" phase of a trial may still come before a jury at the sentencing phase. For further discussion of the evidentiary issues associated with the use of mental health evidence, including competency and diminished capacity, in criminal litigation and capital sentencing determinations, see infra Part I.C and notes $135-37$. 
capacities necessary to realize the project's aspirations; the Article will not address pragmatic objections arising from the technical and interpretive complexities associated with neuroimaging. ${ }^{24}$ Nor will it address evidentiary objections to the use, writ large, of neuroimaging in court. ${ }^{25}$ As the discussion below shows, such evidence, for better or worse, has already been admitted in numerous contexts in numerous courts, ${ }^{26}$ especially for capital sentencing determinations. ${ }^{27}$

The principal goal of this Article is to identify and explain the unintended consequences that the cognitive neuroscience project would have on capital sentencing. The Article leaves for another day the vexed matter of how to proceed in light of this analysis. Rather, it essays to lay an analytical groundwork for a future discussion of whether and how the cognitive neuroscience project might be revised in order to achieve its humanitarian goals.

24 For one such argument, see Stephen J. Morse, Brain Overclaim Syndrome and Criminal Responsibility: A Diagnostic Note, 3 Ohio ST. J. CRIM. L. 397, 400-01 (2006). For a description of the strengths and weaknesses of common neuroimaging techniques, see infra Part I.B.

25 Some commentators urge caution in this regard. See, e.g., Alverson \& Smagac, supra note 11, at 142 ("qEEG brain mapping should not be admissible under either the Frye or the Daubert standards for admissibility of reliable scientific evidence."); Joseph Dumit, Objective Brains, Prejudicial Images, 12 ScI. ConTeXT 173, 190-98 (1999) (arguing that showing brain images to jurors is prejudicial, as such images are manipulable, dynamic, and likely to be misinterpreted by non-expert jurors); Helen S. Mayberg, Functional Brain Scans as Evidence in Criminal Court: An Argument for Caution, 33 J. Nuclear Med. $18 \mathrm{~N}, 18 \mathrm{~N}$ (1992) ("[F]unctional imaging methods have not reached the level of sophistication required to predict any neurological or psychiatric deficit . . ."); Bridget Pratt, Soft Science in the Courtroom? The Effects of Admitting Neuroimaging into Legal Proceedings, 1 Penn Bioethics J. 1, 3 (2005) (arguing that neuroimaging evidence tends to mislead juries and, rather than being presented to juries directly, should be verbally described by expert witnesses); Editorial, Forensic Neuroscience on Trial, 4 N A Ture Neuroscience 1, 1 (2001) (suggesting "extensive field testing" to determine whether EEG scans can measure presence or absence of "incriminating memories" in suspect's mind); Jennifer Kulynych, Note, Psychiatric Neuroimaging Evidence: A High-Tech Crystal Ball?, 49 Stan. L. Rev. $1249,1264-70$ (1997) (suggesting that neuroimaging evidence should be admissible under some circumstances, but advocating two-prong approach wherein courts analyze "technical" components of neuroimage-i.e., whether method for generating neuroimage meets Daubert standard-separately from "inferential" component of such evidence-i.e., evaluation of "inferential leap from the neuroimage to behavioral or psychological judgments").

26 See infra notes 126-34 and accompanying text.

27 See infra Part II.A. 
The Era of Cognitive Neuroscience

\section{A. Cognitive Neuroscience: Its Object and Premises \\ 1. What is Cognitive Neuroscience?}

Cognitive neuroscience is an investigational field that seeks to understand how human sensory systems, motor systems, attention, memory, language, higher cognitive functions, emotions, and even consciousness arise from the structure and function of the brain. ${ }^{28}$ According to Francis Crick, "the overwhelming question in neurobiology" is "the relation between the mind and the brain." 29 Cognitive neuroscience has been described as a "bridging discipline"-between biology and neuroscience, on the one hand, and cognitive science and psychology, on the other. ${ }^{30}$

Interest and activity in the field exploded in the early 1990s, when advances in imaging technology made studying the brain far easier and less invasive than before. ${ }^{31}$ Prior to such advances, many scientists had focused their inquiries on animal and computational models rather than on live human subjects. ${ }^{32}$ The advent of neuroimaging has led to an enormous proliferation of scholarship; over the past five years, an average of one thousand peer-reviewed, neuroimaging-based scholarly articles have been published each month. ${ }^{33}$

The focus of cognitive neuroscience has expanded from an inquiry into basic sensorimotor and cognitive processes to the exploration of more highly complex behaviors. Over the past decade, with the aid of neuroimaging, scientists have increasingly turned their attention to the neurobiological correlates of behavior and to the links between their science and vexed matters of public policy. ${ }^{34}$ Their

28 Howard S. Kirshner, Behavioral Neurology: Practical Science of Mind and Brain 5 (2002). See generally The Cognitive Neurosciences III (Michael S. Gazzaniga ed., 2004) (devoting chapters to "sensory systems," "motor systems," "attention," "memory," "language," "higher cognitive functions," and "emotion").

29 Francis Crick \& Christof Koch, The Problem of Consciousness, Scr. AM., Sept. 1992, at $153,153$.

30 Jamie Ward, The Student's Guide to Cognitive Neuroscience 3 (2006).

31 Bunge \& Kahn, supra note 13; see also OrRin Devinsky \& MARK D'Esposito, Neurology of Cognitive and Behavioral Disorders 52 (2004) (noting that neuroimaging is "noninvasive" and can be used on living patients).

32 KIRSHNER, supra note 28, at 5.

33 David J. Heeger, N.Y. Univ., Mind Reading: Neuroscience Methods and Technology, Presentation at the Judicial Seminar on Emerging Issues in Neuroscience 3 (June 29, 2006), available at http://www.ncsconline.org/d_research/stl/June06/Heeger.pdf.

34 Judy Illes et al., Letter to the Editor, From Neuroimaging to Neuroethics, 6 NATURE NeurosCIENCE 205, 205 (2003) (surveying peer-reviewed articles involving fMRI from 1991 to 2001 and finding "a steady expansion of studies with evident social and policy implications"). Martha J. Farah and Paul Root Wolpe provide a useful taxonomy for the 
efforts are motivated largely by the view, shared by many in the field, that "[a]s we understand more about the details of the regulatory systems in the brain and how decisions emerge in neural networks, it is increasingly evident that moral standards, practices, and policies reside in our neurobiology." 35

Cognitive neuroscientists have thus brought their tools to bear on contested moral and ethical (and, by extension, legal and political) questions, including the moral status of the human embryo, ${ }^{36}$ the brain function of patients diagnosed as minimally conscious or persistently vegetative, ${ }^{37}$ and the definition of "brain death." 38 Furthermore, a number of peer-reviewed articles have addressed the cognitive neuroscience of personality traits such as introversion, ${ }^{39}$ extroversion

recent neuroscience research efforts that touch on moral, social, and public policy questions. They categorize such research under the following headings: "Imaging of Personal Information," "Imaging of Personality," "Imaging of Social and Moral Attitudes," "Imaging of Preferences," "Forensic Imaging," and "Imaging Specific Thoughts." Martha J. Farah \& Paul Root Wolpe, Monitoring and Manipulating Brain Function: New Neuroscience Technologies and Their Ethical Implications, Hastings Center ReP., May-June 2004, at 35, 37-39.

35 Patricia Smith Churchland, Moral Decision-making and the Brain, in Neuroethics: Defining the Issues in Theory, Practice and Policy 3, 3 (Judy Illes ed., 2006).

36 See GazZANiga, supra note 14, at 7-18 (suggesting that fetus should not be considered "one of us" or granted "moral and legal rights of a human being" until it reaches twenty-three weeks, which is when "life is sustainable" outside the womb and fetus could "develop into a thinking human being with a normal brain"). But see Editorial, Morals and the Mind: Michael Gazzaniga's Ethical Brain, 11 New AtLaNTIs 121, 124 (2006) (critiquing Gazzaniga's argument on grounds that embryo before twenty-three weeks is "a selfgenerating organism, an individual life in-process, already the particular person it is destined to become" and that "[a]s important as the brain is to human identity, our mental life is inseparable from our bodily life in subtle but profound ways"). For a comprehensive discussion of the moral, legal, and public policy dimensions of the related debate over stem cell research, see generally The President's Council on Bioethics, Monitoring STEM Cell Research (2004). Gazzaniga is a member of the President's Council on Bioethics, which is charged with advising the White House on the ethical aspects of advancements in biomedical science and biotechnology. This author served as General Counsel to the Council from 2002 to 2005.

37 E.g., N.D. Schiff et al., fMRI Reveals Large-Scale Network Activation in Minimally Conscious Patients, 64 Neurology 514, 522 (2005) (using fMRI to compare brain function of patients in minimally conscious state (MCS) with patients in persistent vegetative state (PVS)). For an overview and discussion of the legal and policy dimensions of one particularly controversial case involving such a patient, see O. Carter Snead, The (Surprising) Truth About Schiavo: A Defeat for the Cause of Autonomy, 22 Const. Comment. 101 (2005).

38 See, e.g., Laurence R. Tancredi, Neuroscience Developments and the Law, in NEUROSCIENCE AND THE LAw, supra note 6, at 71, 72-76 (discussing neuroimaging research on brain death and future legal and policy avenues that might develop from such research).

39 E.g., Debra L. Johnson et al., Cerebral Blood Flow and Personality: A Positron Emission Tomography Study, 156 Am. J. PsychIATRy 252, 254-56 (1999) (finding association between introversion and increased blood flow to frontal lobe). 
and neuroticism,${ }^{40}$ pessimism ${ }^{41}$ empathy,${ }^{42}$ disposition towards cooperation and/or competition, ${ }^{43}$ novelty seeking, harm avoidance, and reward dependence. ${ }^{44}$

Scientists are also investigating the neural mechanisms of emotion, including aversion to unpleasant scenes and social cues (e.g., facial expressions). ${ }^{45}$ There is a growing body of neuroimaging research on social attitudes and preferences, including racial attitudes $^{46}$ (as well as the cerebral processes involved in making judgments about "similar and dissimilar others"),${ }^{47}$ sexual attraction (as well as the neural mechanisms employed in suppressing such attraction), ${ }^{48}$ and political predilections. ${ }^{49}$ Neuroscientists have also

40 E.g., Turhan Canli et al., Amygdala Response to Happy Faces as a Function of Extraversion, 296 SCIENCE 2191, 2191 (2002) (examining correlation between amygdala activity and extraversion and/or neuroticism of test subjects); Turhan Canli et al., An fMRI Study of Personality Influences on Brain Reactivity to Emotional Stimuli, BeHAv. NeuroSCIENCE, Feb. 2001, at 33, 38 (same).

41 E.g., Håkan Fischer et al., Dispositional Pessimism and Amygdala Activity: A PET Study in Healthy Volunteers, 12 NeURoRePORT 1635, 1637 (2001) (utilizing PET scans to examine increased amygdala activity in pessimistic subjects).

42 E.g., Tania Singer et al., Empathy for Pain Involves the Affective But Not Sensory Components of Pain, 303 SCIENCE 1157, 1158-61 (2004) (assessing brain activity associated with empathy through use of $\mathrm{fMRI}$ ).

43 See Illes et al., supra note 34, at 205 (surveying fMRI studies and noting increase in studies touching on topics such as cooperation and competition).

44 See, e.g., Farah \& Wolpe, supra note 34, at 37, 44 n.14 (collecting citations of studies examining these issues).

45 E.g., K. Luan Phan et al., Functional Neuroanatomy of Emotion: A Meta-Analysis of Emotional Activation Studies in PET and fMRI, 16 Neurolmage 331 (2002) (performing meta-analysis of studies of specific brain regions associated with emotional activitation); Paul J. Whalen et al., Masked Presentations of Emotional Facial Expressions Modulate Amygdala Activity Without Explicit Knowledge, 18 J. NeuroscIENCE 411 (1998) (presenting subjects with subliminal cues and scenes).

46 See, e.g., Allen J. Hart et al., Differential Response in the Human Amygdala to Racial Outgroup vs. Ingroup Face Stimuli, 11 NeUroREPORT 2351 (2000) (examining whether brain responds differently when individuals see faces of people of their own race rather than of different race); Elizabeth A. Phelps et al., Performance on Indirect Measures of Race Evaluation Predicts Amygdala Activity, 12 J. Cognitive Neuroscience 729 (2000) (finding that Caucasian subjects respond differently to Caucasian and African American male faces with neutral facial expressions when those faces are unfamiliar but not when faces are familiar and positively regarded); Elizabeth A. Phelps \& Laura A. Thomas, Race, Behavior, and the Brain: The Role of Neuroimaging in Understanding Complex Social Behaviors, 24 Pol. PsYCHOL. 747, 747 (2003) (surveying "neural systems involved in processing race group information").

47 See, e.g., Jason P. Mitchell et al., Dissociable Medial Prefrontal Contributions to Judgments of Similar and Dissimilar Others, 50 Neuron 655, 656 (2006) (suggesting that different parts of brain are involved when making inferences about those similar rather than dissimilar to oneself).

48 See, e.g., Mario Beauregard et al., Neural Correlates of Conscious Self-Regulation of Emotion, 21 J. NeurosCIENCE (RC165) 1, 1 (2001), http://www.jneurosci.org/cgi/reprint/ 21/18/RC165 (measuring brain activation "in normal male subjects while they either 
explored the neurological dimensions of moral decisionmaking ${ }^{50}$ and religious experiences..$^{51}$

Thus, it is hardly surprising that recent neuroimaging studies have touched on matters, including the detection of deception ${ }^{52}$ and the roots of both impulsive and premeditated criminal violence, ${ }^{53}$ that could have forensic applications in various criminal justice contexts. Several of these recent developments approach what might be thought of as "mind reading." Using neuroimaging techniques developed to study high-level vision, scientists have been able to reliably discern the type of image being viewed or imagined by a research subject, based solely on the pattern of activity in the brain. ${ }^{54}$ Most recently, a

responded in a normal manner to erotic film excerpts or voluntarily attempted to inhibit the sexual arousal induced by viewing erotic stimuli").

49 See, e.g., Matthew D. Lieberman et al., Is Political Cognition Like Riding a Bicycle? How Cognitive Neuroscience Can Inform Research on Political Thinking, 24 Pol. PsychOL. 681, 683 (2003) (discussing how cognitive neuroscience may help explain political attitudes); James P. Morris et al., Activation of Political Attitudes: A Psychophysiological Examination of the Hot Cognition Hypothesis, 24 Pol. Psychol. 727, 733, 742 (2003) (testing hypothesis that evaluations of political concepts are stored in brain and automatically activated when those concepts are encountered again).

50 See, e.g., Joshua D. Greene et al., An fMRI Investigation of Emotional Engagement in Moral Judgment, 293 ScIENCE 2105, 2106 (2001) (theorizing that "[s]ome moral dilemmas ... engage emotional processing to a greater extent than others," which then affects moral judgments); Jonathan D. Cohen, Professor of Psychology \& Dir., Ctr. for the Study of Brain, Mind, \& Behavior, Princeton Univ., Neuroscience and Neuroethics: Reward and Decision, Presentation to the President's Council on Bioethics (Jan. 15, 2004), available at $\mathrm{http}: / /$ bioethics.gov/transcripts/jan04/session4.html (discussing theory that brain's processing of emotion explains variations in reactions to moral dilemmas).

51 See Peggy Curran, Soul Search, Gazetre (Montreal), Oct. 19, 2004, at A14 (discussing Mario Beauregard's research on neurological correlates of unio mystica (union with God) experienced by group of cloistered Carmelite nuns in Montreal); Richard Monastersky, Religion on the Brain, Chron. Higher Educ. (Wash., D.C.), May 26, 2006, at A15 (discussing Andrew Newberg's work utilizing SPECT scans to measure brain activity of meditating and praying subjects).

52 See, e.g., Lawrence A. Farwell \& Sharon S. Smith, Using Brain MERMER Testing to Detect Concealed Knowledge Despite Efforts to Conceal, 46 J. Forensic ScI. 135, 135, 143 (2001) (linking evidence of crime to information stored in perpetrator's brain to demonstrate his knowledge of event); D.D. Langleben et al., Brain Activity During Simulated Deception: An Event-Related Functional Magnetic Resonance Study, 15 NeuroImage 727 (2002) (using fMRI to compare brain activity when subjects lied with brain activity when subjects were truthful).

53 For an extensive listing and discussion of current scholarly work on this subject, see infra Part I.D. In addition, there is at least one commercial consulting venture that offers the services of a "forensic neuroscience consultant" as an expert witness or litigation advisor in both civil and criminal matters. Forensic Neuroscience Consultants, Inc., http:// www.forensicneuroscience.com (last visited July 28, 2007).

54 See James V. Haxby et al., Distributed and Overlapping Representations of Faces and Objects in Ventral Temporal Cortex, 293 SCIENCE 2425, 2426-27 (2001) (reporting ability to discern through analysis of brain-scan patterns which of several categories of images subject was viewing); Kathleen M. O'Craven \& Nancy Kanwisher, Mental Imagery of Faces and Places Activates Corresponding Stimulus-Specific Brain Regions, 12 J. Cognitive 
neuroimaging study was published that purported to identify the "covert goals" that a subject intended to perform (specifically, either the addition or subtraction of two given numbers). ${ }^{55}$

The potential social implications of the foregoing sampling of studies are striking. In the words of Judy Illes, director of Stanford University's Program in Neuroethics, this research may ultimately yield the possibility of using neuroimaging when "assess[ing] the truthfulness of statements and memory in law, profiling prospective employees for professional and interpersonal skills, evaluating students for learning potential[,] . . selecting investment managers[,] ... and even choosing lifetime partners based on compatible brain profiles for personality, interests, and desires." 56

\section{Cognitive Neuroscience: The Grounding Premise}

The foundational premise of cognitive neuroscience is that all aspects of the mind are ultimately reducible to the structure and function of the brain. As Joshua Greene and Jonathan Cohen have described it, cognitive neuroscience is the "understanding of the mind as brain." 57 Thus, cognitive neuroscience seeks to provide "comprehensive explanations of human behavior in purely material terms." 58 For purposes of this Article, this approach will be referred to as "reductive materialism." The premise can rightly be termed "reductive" in that it seeks to explain the "macrophenomena" of thought and action solely in terms of the "microphenomena" of the physical brain. ${ }^{59}$ It is "materialist" in that it postulates that human thought and

Neuroscience 1013, 1014 (2000) (contrasting brain activity in response to different classes of visual stimuli).

55 John-Dylan Haynes et al., Reading Hidden Intentions in the Human Brain, 17 CurRENT BIOLOGY 323, 323 (2007).

56 Judy Illes \& Eric Racine, Imaging or Imagining? A Neuroethics Challenge Informed by Genetics, Am. J. Bioethics, Mar./Apr. 2005, at 5, 6.

57 Joshua Greene \& Jonathan Cohen, For the Law, Neuroscience Changes Nothing and Everything, 359 Phil. Transactions Royal Soc'y: Biological Sci. 1775, 1775 (2004) (emphasis added). Neuroscientist David Heeger elaborates: "It's all in the brain--everything about human behavior, human nature, and human society is controlled by the human brain.... If this conjecture is correct, it will be possible with neuroscience methods like fMRI to measure any and all aspects of an individual's mental state (conscious and unconscious)." Heeger, supra note 33, at 6; see also Antonio R. Damasio, How the Brain Creates the Mind, SCI. AM., Dec. 1999, at 112, 117 ("[B]y 2050 sufficient knowledge of biological phenomena will have wiped out the traditional dualistic separations of body/brain, body/ mind and brain/mind.").

58 Martha J. Farah, Neuroethics: The Practical and the Philosophical, 9 Trends CogniTIVE SCI. 34, 34 (2005).

59 See, e.g., Patricia Smith Churchland, Brain-wise: Studies in Neurophilosophy 20-21 (2002) ("[A] reduction has been achieved when the causal powers of the macrophenomenon are explained as a function of the physical structure and causal powers of the microphenomenon."). 
behavior are caused solely by physical processes taking place inside the brain - a three-pound bodily organ of staggering complexity, but a bodily organ nonetheless. ${ }^{60}$ In this way, cognitive neuroscience follows the dominant approach of modern science, which seeks to understand and explain all observable phenomena as functions of their component parts. Under this methodology, questions of biology are thought to be reducible to matters of chemistry, which are, by extension, reducible to problems of physics. ${ }^{61}$ In principle, this approach will ultimately lead to the analysis of all phenomena in terms of the relationships of motion and rest among their most elemental particles. $^{62}$

In defense of reductive materialism in the neuroscience context, proponents cite evidence that "changes in our brain are both necessary and sufficient for changes in our mind." 63 The most well-known example of this principle is the nineteenth-century case of Phineas Gage, a law-abiding railway worker who was radically changed into a callous, unreliable troublemaker following an accident in which an iron tamping rod was driven through his orbitofrontal cortex, the frontal brain region just above and behind the eyes. ${ }^{64}$ As Steven Pinker, a Harvard experimental psychologist, put it:

60 "Materialism" denotes the philosophical premise that only physical things truly exist and, thus, that all phenomena must be explained exclusively in terms of material causes. See, e.g., The Cambridge Dictionary of Philosophy 599-602 (Robert Audi ed., 1995) (defining and discussing materialism as philosophical concept). An alternative descriptor of the cognitive neuroscience premise is "biological mechanism," which "broadly attempts to reduce all vital operations to the laws of physics and chemistry." William A. Wallace, The Elements of Philosophy: A Compendium for Philosophers and Theologians 213-14 (1977). A related philosophical concept, "eliminative materialism," is a doctrine that invokes the findings of cognitive neuroscience to support the assertion that "our common-sense conception of psychological phenomena constitutes a radically false theory, a theory so fundamentally defective that both the principles and the ontology of that theory will eventually be displaced . . . by completed neuroscience." Paul $\mathrm{M}$. Churchland, Eliminative Materialism and Propositional Attitudes, 78 J. PHIL. 67, 67 (1981). For a very fine student comment exploring the implications of this approach for criminal law, see Andrew E. Lelling, Comment, Eliminative Materialism, Neuroscience and the Criminal Law, 141 U. PA. L. Rev. 1471 (1993).

61 See, e.g., Erwin Schrodinger, What is Life? The Physical Aspects of the Living Cell \& Mind AND MatTer 86-91 (Cambridge Univ. Press 1969) (1944) (theorizing that living organisms can be most richly understood and explained in terms of physics and chemistry).

62 See, e.g., Francis Crick, Of Molecules and Men 10-14 (1966) ("The ultimate aim of the modern movement in biology is in fact to explain all biology in terms of physics and chemistry.").

63 Michael S. Gazzaniga \& Megan S. Steven, Free Will in the Twenty-first Century: A Discussion of Neuroscience and the Law, in NEUROSCIENCE AND THE LAw, supra note 6, at $51,52$.

64 See Raymond J. Dolan, On the Neurology of Morals, 2 NATURE Neuroscience 927, 927-28 (1999) (citing J.M. Harlow, Passage of an Iron Rod Through the Head, 39 Boston 
Another problem [with arguments against materialism] is the overwhelming evidence that the mind is the activity of the brain. The supposedly immaterial soul, we now know, can be bisected with a knife, altered by chemicals, started or stopped by electricity, and extinguished by a sharp blow or by insufficient oxygen. Under a microscope, the brain has a breathtaking complexity of physical structure fully commensurate with the richness of the mind. ${ }^{65}$

Reductive materialism is a widely accepted approach among neuroscientists. Michael Gazzaniga recently stated that, in his estimation, "98 or 99 percent" of cognitive neuroscientists share a commitment to reductive materialism in seeking to explain mental phenomena. ${ }^{66}$ This near-universal commitment to using material causation to explain the mind and human behavior carries with it profound implications for perennial concepts such as the existence of the soul, free will, selfhood, and consciousness. As Francis Crick has famously written, "your joys and your sorrows, your memories and your ambitions, your sense of personal identity and free will, are in fact no more than the behavior of a vast assembly of nerve cells and their associated molecules." 67

MEd. \& Surgical J. 389 (1848)) (discussing Harlow's treatment of Gage as well as more recent work of Antonio Damasio on how orbifrontal cortex affects personality). The remarkable thing about Gage's injury is that he suffered such an extreme alteration in personality without similarly losing his cognitive capacities.

Gage's accident is not the only early example of individual misfortune bearing salutary fruits for the development of science. The development of the high-powered rifle and its use in World War I led indirectly to advances in neuroscience, as those soldiers suffering from nonlethal, penetrating head injuries offered doctors unique and theretofore unparalleled opportunities to study the impact that highly localized insults to the brain have on cognition and personality. See, e.g., Walther Poppelreuter, Disturbances of Lower and Higher Visual Capacities Caused by Occipital Damage (Josef Zihl trans., Clarendon Press 1990) (1917) (analyzing data on more than 700 cases of such head injuries sustained during World War I and their effects on brain functions such as vision).

65 Steven Pinker, How the Mind Works 64 (1997).

66 Monastersky, supra note 51 (quoting Gazzaniga).

67 Francis Crick, The Astonishing Hypothesis: The Scientific Search for the Soul 3 (1994); see also Greene \& Cohen, supra note 57, at 1784 (concluding that free will as we understand it is generated by our "cognitive architecture"). Philosopher Patricia Churchland elaborates:

Bit by experimental bit, neuroscience is morphing our conception of what we are. The weight of evidence now implies that it is the brain, rather than some nonphysical stuff, that feels, thinks, and decides. . . [I]t also appears highly doubtful that there is a special nonphysical module, the will, operating in a causal vacuum to create voluntary choices .... The mind that we are assured can dominate over matter is in fact certain brain patterns interacting with and interpreted by other brain patterns. Moreover, one's self, as apprehended introspectively and represented incessantly, is a brain-dependent construct, susceptible to change as the brain changes, and is gone when the brain is gone

CHURCHLAND, supra note 59, at 1-2. 
To be sure, cognitive neuroscientists (and the philosophers who invoke their research) do not universally agree that materialist accounts of human behavior should wholly alter or displace traditional concepts. One could fill many volumes in an effort to give a responsible account of the debates as they have unfolded. On the issue of free will, which is perhaps the most significant for this Article's purposes, some have adopted a posture of "Hard Determinism" (concluding that the reduction of all mental processes to physical events renders the notion of uncaused choice unintelligible), ${ }^{68}$ while others (sometimes called "Compatibilists") adhere to the view that reductive materialism still leaves a limited amount of room for free choice. ${ }^{69}$ In turn, this has profound implications for traditional notions of personal responsibility. Apart from these disagreements, those in the field are of the shared opinion that the findings of cognitive neuroscience compel a deep reevaluation of the philosophical concepts lying at the root of our most weighty moral, ethical, and political decisions. ${ }^{70}$ As will be evident in forthcoming sections, the necessity of reevaluating free will looms large over the aspirations of the cognitive neuroscience project for capital sentencing.

\section{B. Neuroimaging: A Window into the Mind?}

Before proceeding with a discussion and critique of the goals of cognitive neuroscience for capital punishment, it is worth pausing

68 See, e.g., Greene \& Cohen, supra note 57, at 1776 (arguing that "free will, as conceptualized by the folk psychology system, is an illusion").

69 See, e.g., Gazzaniga \& Steven, supra note 63, at 57 (citing work of Benjamin Libet, Conscious vs Neural Time, 352 NATURE 27 (1991), identifying span of only milliseconds in which conscious self can veto particular actions). For a useful discussion of the various positions taken in the debate over free will, see Walter Glannon, Neurobiology, Neuroimaging, and Free Will, 29 Midwest Stud. PhIL. 68 (2005). See also Stephen J. Morse, New Neuroscience, Old Problems, in Neuroscience And the Law, supra note 6, at 169-71 (arguing that new neuroscience studies do not disprove that individuals are conscious, intentional agents).

70 For example, as Judy Illes and Eric Racine put it:

[T] he relationship between the brain and the self is far more direct than the link between genes and personal identity. The locus for integrating behavior resides in the brain, even if discrete features are determined by our genes. Whether neurotechnology measures that behavior through imaging, or manipulates it through implants of neural tissue or devices, it will fundamentally alter the dynamic between personal identity, responsibility, and free will in ways that genetics never has. Indeed, neurotechnologies as a whole are challenging our sense of personhood and providing new tools to society for judging it.

Illes \& Racine, supra note 56, at 14 (citations omitted); see also Farah \& Wolpe, supra note 34 , at 36 ("The brain is the organ of the mind and consciousness, the locus of our sense of selfhood. . . . Our moral and legal conceptions of responsibility are likewise susceptible to change as our understanding of the physical mechanisms of behavior evolves."). 
briefly to describe the technology of neuroimaging itself. It is beyond the scope of this Article to give an exhaustive exegesis of the technical workings of structural and functional neuroimaging. Sufficient for present purposes is an overview of the technology, principles, virtues, and limitations of present-day neuroimaging.

"Neuroimaging" generally refers to the use of various technologies to observe-directly or indirectly-the structure and function of the brain. "Structural" or "anatomical" neuroimaging is limited to the observation of the brain's architecture. "Functional" neuroimaging permits the construction of computerized images that measure the brain's activity with varying degrees of temporal and anatomical resolution, depending on the technology employed. ${ }^{71}$ More recent techniques for functional neuroimaging also allow for the simultaneous imaging of the brain's structure. ${ }^{72}$

\section{Anatomical Techniques}

The two principal techniques for structural neuroimaging are computed tomography (CT) scanning and magnetic resonance imaging (MRI) ${ }^{73}$ CT scanning, introduced in $1972,{ }^{74}$ uses $\mathrm{x}$-rays and a computerized algorithm to reconstruct an image of the brain. ${ }^{75} \mathrm{CT}$ scanning has been largely supplanted by MRI, which has superior spatial resolution. ${ }^{76} \mathrm{MRI}$ constructs a computerized image of the brain by measuring the signal strengths of the various radio frequencies emitted by the proton nuclei of atoms in brain tissue when the protons are placed in a strong magnetic field. ${ }^{77}$

71 Devinsky \& D'Esposito, supra note 31, at 52-53.

72 See id. at 53 (identifying studies linking cognitive processes to specific brain areas).

73 See Bunge \& Kahn, supra note $13, \S 1$ (explaining CT and MRI techniques).

74 Computed tomography was introduced by the British scientist Godfrey Hounsfield, who later shared a 1979 Nobel Prize with American Allan Cormack for its development. The Nobel Prize in Physiology or Medicine 1979, http://nobelprize.org/nobel_prizes/ medicine/laureates/1979 (last visited Aug. 30, 2007).

75 Keith A. Johnson, Neuroimaging Primer, in The Whole Brain Atlas (Keith A. Johnson \& J. Alex Becker eds.), http://www.med.harvard.edu/AANLIB/hms1.html (last visited July 28, 2007).

76 See Bunge \& Kahn, supra note $13, \S 1$ (noting that MRI-which has largely replaced CT scanning-provides excellent detailed structural information and enables naked eye to distinguish gray matter (neuronal cell bodies) from white matter (myelinated tracts)).

77 As Keith Johnson describes it:

When protons (here brain protons) are placed in a magnetic field, they become capable of receiving and then transmitting electromagnetic energy. The strength of the transmitted energy is proportional to the number of protons in the tissue. Signal strength is modified by properties of each proton's microenvironment, such as its mobility and the local homogeneity of the magnetic field. MR signal can be "weighted" to accentuate some properties and not others. 


\section{Functional Techniques}

The first technique allowing the observation of the brain's electrical function was electroencephalography (EEG), introduced by Hans Berger in 1929. ${ }^{78}$ EEG uses electrodes placed on the scalp to directly measure "event related potential"-the total electrical response of a large number of neurons inside the brain. ${ }^{79}$ EEG provides excellent temporal resolution, recording brain activity within milliseconds of its occurrence. ${ }^{80} \mathrm{~A}$ related technique, magnetoencephalography (MEG), directly measures the magnetic fields produced by these same electrical charges from neural activity. ${ }^{81}$ Like EEG, MEG also provides excellent temporal resolution. ${ }^{82}$ However, both EEG and MEG have poor spatial resolution, as neither technique can precisely localize the source of the electrical signal measured. ${ }^{83}$

The more recently developed techniques of functional neuroimaging include positron emission tomography (PET), singlephoton emission computed tomography (SPECT), and functional magnetic resonance imaging (fMRI). ${ }^{84}$ It has long been thought that there is a relationship between neuronal activity and regional cerebral

When an additional magnetic field is superimposed, one which is carefully varied in strength at different points in space, each point in space has a unique radio frequency at which the signal is received and transmitted. This makes constructing an image possible. It represents the spatial encoding of frequency, just like a piano.

Johnson, supra note 75. In 2003, Paul Lauterbur and Peter Mansfield received a Nobel Prize for their discoveries concerning MRI. The Nobel Prize in Physiology or Medicine 2003, http://nobelprize.org/nobel_prizes/medicine/laureates/2003/press.html (last visited June 16, 2007). However, a patent relating to MRI was granted in 1974 to Raymond Damadian. Apparatus \& Method for Detecting Cancer in Tissue, U.S. Patent No. 3,789,832 (filed Mar. 17, 1972) (issued Feb. 5, 1974).

78 Illes \& Racine, supra note 56, at 6.

79 See Devinsky \& D'Esposiro, supra note 31, at 53 (tracing development of EEG and other brain imaging techniques); Illes \& Racine, supra note 56, at 6 (describing EEG as first tool to "unveil fundamental knowledge" about human brain); Bunge \& Kahn, supra note 13, § 4 (explaining technique and usefulness of EEG); Heeger, supra note 33, at 2 (describing EEG as "brain fingerprinting").

80 DEVINSKY \& D'Esposito, supra note 31, at 53; Heeger, supra note 33, at 44.

81 DeVINSKY \& D'Esposito, supra note 31 , at 53; Bunge \& Kahn, supra note $13, \S 4$.

82 Bunge \& Kahn, supra note $13, \S 6$.

83 Id. $\$ 4$.

84 This is not an exhaustive list of the methods of functional neuroimaging, though these do represent the dominant approaches. For a discussion of additional approaches, including optical brain imaging and near-infrared spectroscopy, see Bunge \& Kahn, supra note $13, \S 5.3$. For an overview of proton magnetic resonance spectroscopy and an example of its practical application to the treatment of affective disorders, see Gregory J. Moore \& Matthew P. Galloway, Magnetic Resonance Spectroscopy: Neurochemistry and Treatment Effects in Affective Disorders, 36 Psychopharmacology Bull. 5, 14-18 (2002). 
blood flow-that is, blood flow to the region of the brain that is active during a given task. ${ }^{85}$ PET, SPECT, and fMRI all depend on this principle: once a threshold level of neuronal activity is reached, PET, SPECT, and fMRI indirectly measure highly localized brain activity by recording certain proxies associated with cerebral blood flow. ${ }^{86}$

For instance, PET and SPECT require the injection of small amounts of radiolabeled molecules-radioactive tracer compoundsinto the bloodstream, which enter the brain after approximately thirty seconds. ${ }^{87}$ These molecules show either the uptake of nonmetabolized congeners of glucose (which is equated with increased cellular activity), the anatomical distribution of specific proteins (e.g., transporters), or specific neuronal functions (such as the displacement of a neurotransmitter from its receptor). ${ }^{88}$ In PET, the radiolabeled molecules (e.g., 2-deoxyglucose) are absorbed and concentrated in tissue just as if they were a natural compound (e.g., glucose). ${ }^{89}$ The tracer compounds begin to decay, thus emitting positrons that can be detected and observed, allowing for the production of

85 See Bunge \& Kahn, supra note 13, \$ 5.1 ("[Charles Smart] Roy and [Sir Charles] Sherrington first showed in $\mathbf{1 8 9 0}$ that brain stimulation led to a local increase in blood flow to active populations of neurons."); see also Richard B. BuXTON, INTRODUCTION TO Functional Magnetic Resonance Imaging: Principles and Techniques 3 (2002) ("[W]e must suppose a very delicate adjustment whereby the circulation follows the needs of the cerebral activity. Blood very likely may rush to each region of the cortex according as it is most active, but of this we know nothing." (quoting William James's 1890 observation)).

86 See, e.g., Devinsky \& D'Esposito, supra note 31, at 53 (noting that modern functional brain imaging methods "measure changes in cerebral blood flow" and consequently "provide an indirect but highly localized measure of increases in neural activity").

87 Bunge \& Kahn, supra note $13, \S 5.1$.

88 See David J. Brooks, Positron Emission Tomography and Single-Photon Emission Computed Tomography in Central Nervous System Drug Development, 2 NeuroRx J. AM. Soc'y Experimental NeuroTherapeutics 226, 229-30 (2005) (describing molecules showing cerebral glucose metabolism, loss of striatal dopamine function, and distribution of amyloid peptides and microtubule-associated peptides in brain). As Brooks explains:

Positron emission tomography (PET) and single-photon emission computed tomography (SPECT) provide a means of examining regional cerebral blood flow, metabolism, and pharmacology in vivo under both resting and activating conditions. These molecular imaging techniques rely on radiolabeled molecules (tracers) that bind to enzyme sites or surface receptors. PET utilizes short-lived positron emitting isotopes $\left({ }^{15} \mathrm{O},{ }^{11} \mathrm{C},{ }^{18} \mathrm{~F},{ }^{76} \mathrm{Br}\right)$, whereas SPECT uses lower energy $\gamma$-emitting isotopes $\left({ }^{123} \mathrm{I},{ }^{99 \mathrm{~m}} \mathrm{Tc}\right)$. Both techniques can detect nanomoles of tracer, but PET has the advantage that it is more sensitive and versatile and allows scatter correction to be performed. SPECT is, however, cheaper and more widely available as it does not rely on a local cyclotron for production of isotopes.

Id. at 226.

89 For an overview of the radioisotopes used in PET scans, see Mayfield Clinic, Positron Emission Tomography (PET) Scan, http://www.precisionradiotherapy.com/PE-PET. htm (last visited July 28, 2007). 
images that map the distribution of the tracer compounds throughout the brain. ${ }^{90}$ SPECT differs from PET in that it uses different tracer compounds-ones that remain in the bloodstream instead of being absorbed. Thus, SPECT images are limited to areas of blood flow. ${ }^{91}$ Whether using PET or SPECT, researchers infer that the areas with the highest observed metabolic activity are the regions of greatest brain activation during the task under study.

The advantage of PET and SPECT over other approaches, such as fMRI, is that researchers can customize the radiolabeled compounds to study very specific metabolic or pharmacological activities in the brain; this allows researchers to target their studies towards the function of specific neurotransmitter systems. ${ }^{92}$ Despite this virtue, PET and SPECT share several weaknesses. First, they both require the injection of radioactive material into a human subject, which creates nontrivial risks, prevents multiple trials over a short period of time, and precludes their use in certain human subjects, such as children. ${ }^{93}$ Both also have poor temporal resolution, with a delay of up to thirty minutes between the activity and the measurement. ${ }^{94}$ Moreover, both PET and SPECT are very expensive techniques. ${ }^{95}$ These disadvantages have led researchers to turn elsewhere, and they have settled on fMRI as their preferred functional neuroimaging technique.

fMRI has eclipsed all other techniques as the most widely used form of functional neuroimaging. ${ }^{96}$ Like PET and SPECT, it relies on the principle that regional brain activation is indicated by increased

90 University of Washington, Division of Nuclear Medicine, Introduction to PET Physics: The Physical Principles of PET, $\S 2.1$, http://depts.washington.edu/nucmed/IRL/ pet_intro/intro_src/section2.html (last visited July 28, 2007).

91 Mayfield Clinic, Single Photon Emission Computed Tomography (SPECT), http:// www.mayfieldclinic.com/PE-SPECT.htm (last visited July 28, 2007).

92 Bunge \& Kahn, supra note 13, § 5.1.

93 See, e.g., Devinsky \& D'Esposito, supra note 31, at 53 (noting that PET's use "was limited by the need for radioactive tracers to measure cerebral blood flow"); Bunge \& Kahn, supra note $13, \S 5.1$ (explaining PET's disadvantages); Mayfield Clinic, supra note 89 (noting that pregnant or nursing women should not undergo PET scans); Mayfield Clinic, supra note 91 (noting that pregnant or nursing women should not undergo SPECT scans).

94 Illes \& Racine, supra note 56, at 8 (noting that PET's limitations include "lag time of up to 30 minutes between stimulation and data acquisition"); Nora D. Volkow et al., Imaging the Living Human Brain: Magnetic Resonance Imaging and Positron Emission Tomography, 94 Proc. NAT'L ACAD. SCI. U.S. 2787, 2787 tbl.1 (1997) (comparing temporal resolution of PET, SPECT, and other imaging techniques); see also Bunge \& Kahn, supra note 13, § 5.1 (explaining poor temporal resolution of PET).

95 See Illes \& Racine, supra note 56, at 8 (noting that there are fewer than one hundred PET scanners in United States today and that use of both PET and SPECT may be limited due to cost).

96 Devinsky \& D'Esposrto, supra note 31 , at 55; Bunge \& Kahn, supra note $13, \S 5.2$; see also Illes \& Racine, supra note 56 , at 7 ("It is the widespread availability of MR scan- 
cerebral blood flow. Whereas PET and SPECT utilize the proxies of blood flow and metabolic activity (e.g., glucose metabolism) of brain cells, fMRI measures the surplus of oxygenated blood recruited to the active brain region under consideration. ${ }^{97}$ When the brain activity in a particular region increases, so too does the concentration of oxygenated blood (the "hemodynamic response"), ${ }^{98}$ while the concentration of deoxygenated blood simultaneously decreases. Deoxygenated blood contains deoxyhemoglobin, which is paramagnetic; that is, its presence causes a decrease in the magnetic resonance signal. 99 When oxygenated blood flows to a brain region (and the concentration of deoxyhemoglobin decreases), the magnetic resonance signal increases-a phenomenon referred to as the blood oxygenated leveldependent (BOLD) response. 100 Researchers interpret the increase in cerebral blood flow to a particular brain region (indicated by an increase in magnetic resonance signal strength) as an increase in cellular activity in that particular region. ${ }^{101}$

fMRI has numerous advantages over PET and SPECT. ${ }^{102}$ It is noninvasive and seemingly harmless. ${ }^{103}$ Its spatial resolution is excellent. ${ }^{104}$ Its temporal resolution is superior to other indirect methods

ners today and the noninvasiveness of the imaging approach enabled by MR [that] have set fMRI apart from other neuroimaging tools ....").

97 Illes \& Racine, supra note 56, at 8; Bunge \& Kahn, supra note 13, § 5.2 ("It is this surplus of oxygen that is detected with fMRI, with what is known as the blood oxygen-level dependent (BOLD) contrast.").

98 Bunge \& Kahn, supra note $13, \S 5.2$; see also Devinsky \& D'Esposito, supra note 31 , at 56 (explaining that neural event in brain region increases local blood flow and concentration of oxygenated blood, which "leads to an increase in the fMRI signal").

99 Devinsky \& D'Esposito, supra note 31, at 56.

100 See id. (providing more detailed explanation of physiological and electromagnetic dimensions of clinical MRI methods). The term "fMRI" typically refers to the MRI technique that utilizes the BOLD response to measure increased oxygen demand by nerve cells. Other MRI methods provide insight into physiological function (e.g., "arterial spin labeling" and "intravenous bolus tracking," which are both categorized as types of "perfusion MRI"), the anatomy of nerve fiber tracts ("diffusion-weighted imaging"), and levels of certain neurochemicals ("MR spectroscopy"). For a description and discussion of these approaches, see Jeffrey P. Lorberbaum et al., Functional Magnetic Resonance Imaging (fMRI) for the Psychiatrist, http://www.musc.edu/fnrd/primer_fmri.htm (last visited July $28,2007)$.

101 Devinsky \& D'Esposito, supra note 31, at 56.

102 See Bunge \& Kahn, supra note $13, \S 5.2$ (listing advantages of fMRI as (1) wide availability of MRI technology, (2) low per-scan costs, (3) lack of recognized risks, (4) good spatial resolution, and (5) superior temporal resolution relative to other techniques).

103 See Devinsky \& D'Esposito, supra note 31, at 55 ("[I]n addition to not requiring the injection of a radioisotope, fMRI is noninvasive ...."); Illes \& Racine, supra note 56, at 8 (including "[n]oninvasive[ness], study repeatability, [and] no known risks" among fMRI strengths).

104 See Devinsky \& D'Esposito, supra note 31, at 55 (indicating that $\mathrm{fMRI}$ has spatial resolution in millimeters while PET's spatial resolution is in centimeters). 
of functional neuroimaging (e.g., PET and SPECT), ${ }^{105}$ though inferior to EEG and MEG ${ }^{106}$ (which have far inferior spatial resolution, as noted above). It is widely thought that fMRI, among all neuroimaging techniques, best balances temporal and spatial resolution. ${ }^{107}$

\section{Potential Difficulties}

It is beyond the scope of this Article to discuss at length the potential technical and interpretive difficulties that accompany the efforts to use neuroimaging to draw inferences about morally and socially relevant behavior, and these difficulties have been explored extensively elsewhere. ${ }^{108}$ Rather, the present inquiry will assume for

105 Bunge \& Kahn, supra note $13, \S 5.1$.

106 See Devinsky \& D'Esposito, supra note 31, at 56 (noting that sluggishness of hemodynamic response "limits the temporal resolution of the fMRI signal to a few seconds as opposed to the millisecond temporal resolution of electrophysiological recordings of neural activity" like EEG or MEG). It is noteworthy that while fMRI's temporal resolution is superior to PET's or SPECT's, the hemodynamic response measured by fMRI is orders of magnitude slower than the underlying neural activity for which it is a proxy. Id.

107 Id. at 57; Illes \& Racine, supra note 56, at 7. For a discussion of the technical disadvantages of $\mathrm{fMRI}$ (including temporal resolution), as well as experimental design issues, statistical errors, methodological limitations, and a further account of the types of hypotheses that are best suited to fMRI, see DEvinsKy \& D'Esposito, supra note 31, at 57-65.

108 See, e.g., Joseph Dumit, Picturing Personhood: Brain Scans and Biomedical IDENTITY 15-16 (2004) (discussing assumptions about "human nature," "how the brain works," and how "person and brain are related" that are embedded in brain-imaging studies); John Horgan, The Undiscovered Mind: How the Human Brain Defies REPLICATION, MEDICATION, AND EXPLANATION 21-23 (1999) (arguing that neuroimaging studies overemphasize role of brain's subdivisions as separate entities and fail to explore relationships between brain's different parts); Anne Beaulieu, Images Are Not the (Only) Truth: Brain Mapping, Visual Knowledge, and Iconoclasm, 27 SCI. TeCH. \& Hum. Values 53, 62 (2002) (noting view of some scientists that neuroimaging work is simply "making pretty pictures" and "is at best observational and not the scientific study of function"); Joseph Dumit, Twenty-First-Century PET: Looking for Mind and Morality Through the Eye of Technology, in Technoscientific Imaginaries: Conversations, Profiles, and Memoirs 87, 96-104 (George E. Marcus ed., 1995) (presenting interviews with several "fathers" of PET scanning and addressing PET's interpretive difficulties and technical limitations and misleading use of PET images); Joseph Dumit, When Explanations Rest: 'Good Enough' Brain Science and the New Socio-Medical Disorders, in Living AND Working with THE New Medical Technologies 209, 209-11 (Margaret Lock et al. eds., 2000) (undertaking an "ethnographic characterization" of "the new socio-medical disorders," including chronic fatigue and Gulf War syndromes and post-traumatic stress disorder, to show "how scans and other biological evidence are usually not the final word on these disorders"); Farah \& Wolpe, supra note 34, at 40 (discussing "illusory accuracy" of brain scans and describing interpretive difficulties); Illes \& Racine, supra note 56, at 12-15 (addressing interpretive difficulties due to technical limitations of neuroimaging studies and various cultural and religious preconceptions); Kelly Joyce, Appealing Images: Magnetic Resonance Imaging and the Production of Authoritative Knowledge, 35 Soc. STUD. ScI. 437, 448-53 (2005) (describing obstacles to proper interpretation of fMRI scans); S.M. Kosslyn, If Neuroimaging Is the Answer, What Is the Question?, 354 PhiL. Transactions Royal SOC'Y: BiOlOGiCAL SCI. 1283, 1283 (1999) (noting that neuroimaging techniques are not well-suited to "exploratory," open-ended inquiries and proposing instead specific 
the sake of argument that neuroimaging can yield significant insights into the brain's anatomy and related functions that are relevant to morality, law, and public policy. This Article seeks to analyze the cognitive neuroscience project according to its own aspirations without regard to practical, technical, and epistemic concerns. Nevertheless, it is useful to acknowledge and review the most commonly raised objections to the project in the scholarly discourse to date.

One concern is that, given the profound obstacles to isolating, controlling, and studying cognitive processes, it is quite difficult to show a conclusive relationship of necessity between a particular brain region's function and any associated cognitive process. ${ }^{109}$ Relatedly, there is the usual experimental difficulty of distinguishing causation from mere correlation. ${ }^{110}$ Concerns have also been raised about the notion of functional specialization of brain regions, a premise that is central to neuroimaging studies. ${ }^{111}$ That is, certain brain regions may serve multiple cognitive functions or, alternatively, multiple cognitive

questions that such techniques might actually resolve); Neuroethics Needed: Researchers Should Speak Out on Claims Made on Behalf of Their Science, 441 NATURE 907, 907 (2006) (noting that some scientists disapprove of using fMRI scans as lie-detector tests because "there is scant evidence that [fMRI scans] can reliably distinguish a lie from the truth in any individual case"); Richard Robinson, fMRI Beyond the Clinic: Will It Ever Be Ready for Primetime?, 2 Pub. LiBr. SCI. Bıology 715, 716 (2004) (noting limitations of current fMRI techniques and arguing that while fMRI may shed light on brain functioning in general, it does not explain brain functioning in any particular individual); Sam Jaffe, Fake Method for Research Impartiality (fMRI), ScIENTIST, July 19, 2004, at 64 (criticizing fMRI's poor temporal resolution and noting that fMRI measures proxies for brain activity rather than brain activity itself).

109 See, for example, Devinsky \& D'Esposito, supra note 31, at 53-54, who explain:

When a subject performs a task during imaging, it is difficult to demonstrate conclusively that he or she is differentially engaging a single, identified cognitive process. The subject may engage in unwanted cognitive processes that either have no overt, measurable effects or are perfectly confounded with the process of interest. Consequently, the neural activity measured by the functional neuroimaging technique may result from some confounding neural computation that is itself not necessary for executing the cognitive process under study.

There are, however, some experimental techniques, such as transcranial magnetic stimulation (TMS), which temporarily isolate or disrupt the function of targeted brain regions, allowing researchers to draw inferences about the sufficiency or necessity of the given region to the particular cognitive activity under study. See, e.g., Dennis J.L.G. Schutter et al., Introducing Transcranial Magnetic Stimulation (TMS) and Its Property of Causal Inference in Investigating Brain-Function Relationships, 141 SYNTHESE 155, 155 (2004) ("TMS can serve as a heuristic method for resolving causal issues in an arena [i.e., neuronal function] where only correlative tools have traditionally been available.").

110 Similarly, there is the difficulty of identifying whether it is the brain that is generating the observed behavior or whether external experiences and behavior are shaping the structure and function of the brain.

111 See, e.g., Heeger, supra note 33, at 21-31 (noting importance of premise of functional specialization). 
functions may activate the same region of the brain. ${ }^{112}$ This increases the risk of error in drawing inferences from neuroimaging data about the brain, the mind, and behavior. This difficulty is compounded because the most common forms of neuroimaging use indirect measures of brain activity. Depending on the technique, either blood flow or metabolic activity (with PET and SPECT) or the concentration of oxygenated blood (with fMRI) serve as proxies for studying regional brain activity. ${ }^{113}$ Thus, the measurements derived from these techniques are necessarily attenuated from the ultimate object of interest-namely, cognitive function. ${ }^{114}$

These concerns, in turn, have led to concerns about the interpretation of the data generated by neuroimaging. As Martha J. Farah and Paul Root Wolpe have observed, "Although brainwaves do not lie, neither do they tell the truth; they are simply measures of brain activity."115 Furthermore, the array of expertise required to produce a single neuroimage (i.e., neuroscience, computational theory, physics, computer science, statistical analysis, and nuclear medicine) presents numerous opportunities for technical error. ${ }^{116}$ There is also a lack of standardization among the machines and laboratory procedures used

112 See, e.g., DEVINSKy \& D'Esposito, supra note 31, at 54-55 ("[A]ssuming that a particular brain region is activated by a cognitive process (evoked by a particular task), the neural activity in that brain region must depend on engaging that particular cognitive process. . . . However, this region may also support other cognitive processes."). Stephen Kosslyn notes that it is not yet understood whether brain activation (as measured by neuroimaging) indicates excitation or inhibition of function since both excitatory and inhibitory neurons produce a metabolic demand when active. Kosslyn, supra note 108, at 1292.

113 Additional concerns have been raised that the indirect proxies measured (i.e., neural activity and hemodynamic response) take place on a time scale that is orders of magnitude slower than the underlying neural events. See supra note 106.

114 A potent rejoinder might be that the brain is the locus of the mind and, therefore, that the attenuation between the proxies measured by neuroimaging and the mental activity itself is smaller than the attenuation between the mind and the measurement taken by the instruments of traditional psychology (such as personality questionnaires) or other forensic methods (such as conventional polygraphs). See Farah \& Wolpe, supra note 34, at 40 ("Brain-based measures . . . . are one causal step closer to [psychological] traits and states than responses on personality questionnaires or polygraph tracings.").

115 Id.

116 See Farah, supra note 58, at 35 ("[T] layers of signal processing and statistical analysis that intervene between actual brain function and resulting image or waveform, as well as the complex set of assumptions required ...."); Illes \& Racine, supra note 56, at 13 ("[T]he brain image represents unparalleled complexity-from the specialized medical equipment needed to acquire a scan, to the array of parameters used to elicit activations and the statistical thresholds set to draw out meaningful patterns, to the expertise required for the objective interpretation of the maps themselves."); Reeves et al., supra note 16, at 90 (explaining that image generation involves "many assumptions, corrections, and compromises and various levels of analysis," and that process is "easily manipulated by a person with knowledge of the technology"). 
in the field. ${ }^{17}$ The wide variability in brain physiology among experimental subjects and the concomitant difficulties in defining normalcy also make it difficult to draw meaningful comparisons. ${ }^{118}$ Thus, while it is among the most powerful new tools available, fMRI is rarely used for diagnostic applications and has not yet become part of standard practice for clinicians. ${ }^{119}$

An additional concern is that the use of cognitive neuroimaging data to diagnose psychological conditions relies entirely on the soundness of the diagnostic criteria-which, given the absence of specific biological markers for any psychiatric disorder, can be hotly contested. ${ }^{120}$ Moreover, the "[i]nterpretation of neuroimaging studies [is] not only bound by scientific frameworks, but also cultural and anthropological ones."121 Concepts which are integral to the interpretation of cognitive neuroimaging, such as "personhood," "self," and "consciousness," can vary widely from culture to culture. This only adds further complexity to the analysis of data acquired in such studies. ${ }^{122}$ Finally, there is a worry that people will ignore the foregoing technical and interpretive complexities in a rush towards practical application, especially given the current enthusiasm about the potential of

117 See Illes \& Racine, supra note 56, at 13 (noting an "absence of standards of practice in the laboratory" that adds "another layer of complexity for drawing conclusions"); Reeves et al., supra note 16, at 90 (noting that neuroimaging "steps are not standardized from one technology to the next or from one machine or laboratory to the next").

118 See Devinsky \& D'Esposito, supra note 31, at 63 ("[T] tion . . cannot be compared directly between groups of subjects."); Illes \& Racine, supra note 56 , at 13 (noting that functional imaging results may be "subject to physiologic and day-to-day variations"); Reeves et al., supra note 16, at 90 ("The definition of normal may be ambiguous in brain imaging.").

119 See, e.g., Farah \& Wolpe, supra note 34, at 37 (explaining that fMRI is not yet reliable "at the individual patient level"). However, much has been written about the possibility of using fMRI in clinical practice, particularly in "presurgical planning and prognosis" of intractable epilepsy, arteriovenous malformations, and brain tumors, as well as for Alzheimer's disease and other forms of dementia. See Devinsky \& D'Esposito, supra note 31, at 63-64, $67 \mathrm{nn} .93-104$ (discussing clinical applications of fMRI and citing twelve other studies).

120 Indeed, the objectivity and validity of the criteria proposed in AM. PsYchiatric Ass'n, Diagnostic and Statistical Manual of Mental Disorders (4th ed. 1994) [hereinafter DSM-IV], have long been a matter of discussion and controversy. See, e.g., Peter S. Jensen \& Kimberly Hoagwood, The Book of Names: DSM-IV in Context, 9 DEV. \& PSYCHOPATHOLOGY 231, 231 (1997) ("[C]ontroversies continue concerning the validity of these taxonomies, as well as about the types of measures and instruments purported to measure the psychopathologic constructs." (citations omitted)).

121 Illes \& Racine, supra note 56, at 14.

122 See id. ("For example, central to Buddhism is the Doctrine of No-Soul, whereas in Hinduism, the self is a religious and metaphysical concept. Even within Western traditions, that may appear to be monolithic, various beliefs have served as "sources of the self.'" (citations omitted)). 
neuroimaging to provide seemingly objective and transparent insight into morally and socially relevant behaviors. ${ }^{123}$

\section{Neuroimaging and the Law Generally}

Developments in neuroimaging have affected the law both directly and indirectly. The indirect developments are visible in the great deal of discussion that has occurred about speculative applications of nascent technological innovations. The direct impact has occurred where neuroimaging evidence has been introduced in courtrooms and has led to the creation of a body of decisional law that has shaped the legal landscape in this domain.

Henry Greely has provided an excellent account of the speculative uses of neuroimaging in the legal context. He suggests that such technology might eventually be used in the courtroom to detect lies or to compel truth, to determine bias (on the part of jurors, witnesses, or parties), to elicit or evaluate memory, to determine competency (e.g., to stand trial, to be executed, or to make medical decisions), to prove the presence of intractable pain, to prove addiction (or susceptibility thereto), to show a disposition to sexual deviance or predatory impulses (for purposes of involuntary civil commitment), or to show future dangerousness. ${ }^{124}$

As for actual applications, neuroimaging evidence has been proffered and admitted in a variety of jurisdictions, in both civil and crim-

123 See, e.g., Farah \& Wolpe, supra note 34, at 40 (observing that potential utility of neuroimaging for employers, schools, military, and legal systems, "coupled with the inevitable misunderstandings of brain imaging among the lay public, sets the stage for misuse"); Illes \& Racine, supra note 56, at 13 ("With dynamic images in hand, we may forget the epistemological limits of how the images were produced, including variability in research designs, statistical treatment of the data, and resolution."). As always, it bears noting that a functional neuroimage is not a photograph of the brain, but rather "a computer-generated visual representation of numerical measurements-in this case, measurements of a physiological event." Kulynych, supra note 25, at 1254.

124 Henry T. Greely, Prediction, Litigation, Privacy and Property: Some Possible Legal and Social Implications of Advances in Neuroscience, in NEUROSCIENCE AND THE LAw, supra note 6 , at 114, 127-48. An additional potential application of neuroimaging to the criminal context is in showing subjective predispositions to a particular criminal activity for the purpose of defeating entrapment defenses. To prevail against a claim of entrapment, the government must prove that the defendant already had the predisposition to engage in the criminal activity at issue, such that the government merely facilitated its commission. See Jacobson v. United States, 503 U.S. 540, 548-49 (1992) ("[When] the defense of entrapment is at issue ... the prosecution must prove beyond reasonable doubt that the defendant was disposed to commit the criminal act prior to first being approached by Government agents."); United States v. Russell, 411 U.S. 423, 435-36 (1973) ("It is only when the Government's deception actually implants the criminal design in the mind of the defendant that the defense of entrapment comes into play."). 
inal cases and for a variety of purposes. ${ }^{125}$ However, it is difficult to analyze the use of neuroimaging in actual litigation. Many cases in which neuroimaging evidence is introduced may be unreported. Still others may be resolved through informal means, such as settlement or plea agreement. To the extent that such cases can be identified, it is often impossible to reliably discern the role that neuroimaging evidence played in the outcome. What follows is a very brief survey of some circumstances in which neuroimaging evidence has been both introduced and admitted.

In the civil context, neuroimaging has been proffered and admitted to prove actual harm (and, to a lesser extent, causation) in personal injury cases involving toxic exposure, ${ }^{126}$ claims under the National Vaccine Act, ${ }^{127}$ head injuries, ${ }^{128}$ and medical malpractice. ${ }^{129}$

125 Neuroimaging evidence has been admitted in jurisdictions that follow the standard for the admissibility of scientific and expert testimony (under FED. R. EvID. 702) announced in Daubert v. Merrill Dow Pharmaceuticals, Inc., 509 U.S. 579, 589 (1993) (holding that trial judge must determine whether expert testimony is both "relevant" and "reliable"), and refined by General Electric Co. v. Joiner, 522 U.S. 136, 141-43 (1997) (holding that trial court's decision to admit or exclude expert testimony is subject to review for abuse of discretion), and Kumho Tire, Ltd. v. Carmichael, 526 U.S. 137, 147, 150-51 (1999) (holding that Daubert applies to all expert testimony and that Daubert factors are "helpful, not definitive"), as well as in those jurisdictions that follow the older standard announced in Frye v. United States, 293 F. 1013, 1014 (D.C. Cir. 1923) (holding that expert testimony must be based on knowledge that has "gained general acceptance in the particular field"). See An Overview of the Impact of Neuroscience Evidence in Criminal Law (2004) (President's Council on Bioethics Staff Working Paper), available at http://www. bioethics.gov/background/neuroscience_evidence.html (discussing cases in both Frye and Daubert jurisdictions in which neuroimaging evidence was admitted).

126 E.g., Hose v. Chi. Nw. Transp. Co., 70 F.3d 968, 973 (8th Cir. 1995) (PET evidence admitted to show injuries consistent with manganese encephalopathy); Rhilinger $v$. Jancsics, No. 932223, 1998 WL 1182058, at *4 (Mass. Super. Ct. Jan. 6, 1998) (holding that use of SPECT to show injuries consistent with toxic encephalopathy was "scientifically reliable" under Daubert). But see Summers v. Mo. Pac. R.R. Sys., 897 F. Supp. 533, 540 (E.D. Okla. 1995) (excluding expert testimony that relied heavily on SPECT to diagnose neurotoxic exposure).

127 E.g., Bushell v. Sec'y of Health \& Human Servs., No. 91-1270V, 1993 WL 212472, at *2-4 (Fed. Cl. June 3, 1993) (deeming PET evidence relevant and credible to expert's claim that DPT (diphtheria, pertussis, tetanus) vaccine did not cause seizures). But see GardnerCook v. Sec'y of Health \& Human Servs., 59 Fed. Cl. 38, 41-42, 49 (2003) (affirming finding that neither SPECT nor PET were admissible for diagnosing brain injury in question).

128 E.g., Boyd v. Bert Bell/Pete Rozelle NFL Players Ret. Plan, 410 F.3d 1173, 1177 (9th Cir. 2005) (considering SPECT scan presented by plaintiff in attempt to prove causation and injury in ERISA claim arising from football head injury); Fini v. Gen. Motors Corp., No. 227592, 2003 WL 1861025, at *2-5 (Mich. Ct. App. Apr. 8, 2003) (affirming trial court's finding that SPECT evidence was admissible under Frye to prove head injuries from automobile accident); Baxter v. Ohio Dep't of Transp., No. 02AP-537, 2002 WL 31838505, at *4-7 (Ohio Ct. App. Dec. 19, 2002) (finding that trial court erred in disregarding plaintiff's SPECT evidence showing diminished brain activity after automobile accident). But see Penney v. Praxair, Inc., 116 F.3d 330, 332-33 (8th Cir. 1997) (noting lower court's finding 
In a recent suit by a video game industry trade association to enjoin the enforcement of the Illinois Violent Video Games Law (VVGL) ${ }^{130}$ and Sexually Explicit Video Games Law (SEVGL), ${ }^{131}$ a federal district court admitted fMRI evidence to show a relationship between playing violent video games and aggressive behavior in children. ${ }^{132}$ The fMRI evidence was tendered in support of the government's argument that it had a compelling state interest in regulating violent games. ${ }^{133}$ In contract disputes, neuroimaging has been admitted-and has been found persuasive by fact finders-to show that one of the parties lacked sufficient cognitive capacity to form a valid contract. ${ }^{134}$

In the criminal context, defendants have proffered neuroimaging evidence at various stages of the process for a variety of purposes. For instance, courts have admitted neuroimaging evidence (or have held that a defendant was entitled to undergo neuroimaging tests) in connection with claims of mental incompetence. ${ }^{135}$ Defendants have had mixed success in seeking to admit neuroimaging evidence to show diminished capacity (or an inability to formulate requisite mens rea) at the guilt phase of criminal trials ${ }^{136}$ or as an adjunct to their insanity

that PET evidence would "not be helpful to the jury in deciding the issues when compared with the likelihood that the jury would misapply the evidence" and affirming lower court's holding on new grounds that "plaintiffs failed to establish a sufficient foundation" to show that evidence was reliable).

129 See, e.g., Matuszak v. Cerniak, 805 N.E.2d 681, 683-84 (Ill. App. Ct. 2004) (affirming trial court's decision to admit SPECT evidence to demonstrate actual harm and to find that it did not establish causation).

130720 Ill. Comp. Stat. Ann. 5/12A-1 to -25 (West Supp. 2007).

131720 Ill. Comp. Stat. AnN. 5/12B-1 to -35 (West Supp. 2007).

132 Entm't Software Ass'n v. Blagojevich, 404 F. Supp. 2d 1051, 1063-67 (N.D. Ill. 2005).

133 See id. (admitting fMRI evidence but ultimately rejecting government's "compelling interest" claim and noting that fMRI evidence was not yet convincing or conclusive).

134 Van Middlesworth v. Century Bank \& Trust Co., No. 215512, 2000 WL 33421451, at *2-4 (Mich. Ct. App. May 5, 2000) (contract held voidable based in part on MRI showing brain shrinkage and hardening of arteries consistent with dementia). For an extended survey and discussion of various civil cases involving neuroimaging evidence, see $O$. Carter Snead, Neuroimaging and the Courts: Standards and Illustrative Case Index, Presentation at Judicial Seminar on Emerging Neuroscience Issues 2-6 (June 29, 2006), available at http://www.ncsconline.org/d_research/stl/June06/Snead.doc.

135 However, courts sometimes find such evidence, once admitted, to be unpersuasive. See, e.g., United States v. Hammer, 404 F. Supp. 2d 676, 722-25 (M.D. Pa. 2005) (entertaining MRI, PET, and computerized neuropsychological testing evidence but ultimately finding it unpersuasive as to competency); United States v. Gigante, 982 F. Supp. 140, 147-48 (E.D.N.Y. 1997) (finding PET scan evidence unreliable and unconvincing); State v. Marshall, 27 P.3d 192, 199 (Wash. 2001) (holding that, where competency is at issue at time of trial, sentencing, or punishment, defendant is entitled to assistance of expert testimony and testing, here including neuroimaging (MRI)).

136 See, e.g., United States v. Mezvinsky, 206 F. Supp. 2d 661, 674-75 (E.D. Pa. 2002) (holding PET scan inadmissible because scan was not relevant to whether defendant had "capacity to deceive" or requisite mens rea for charges); People v. Yum, 3 Cal. Rptr. 3d 855, 857 (Ct. App. 2003) (barring SPECT evidence offered to show diminished capacity 
defenses. ${ }^{137}$ The most famous example of neuroimaging being used in an insanity defense is the case of John Hinckley, Jr., who attempted to assassinate President Ronald Reagan in 1981. There, the court admitted a CT scan to show that Hinckley's brain had atrophied, which the defense argued-over the vigorous argument of the government's expert-was evidence of organic brain disease. ${ }^{138}$

Defendants have enjoyed the greatest success with neuroimaging evidence at the sentencing phase of capital trials in connection with mitigation claims. ${ }^{139}$ In support of these claims, experts have invoked cutting-edge neuroimaging research on the biological correlates of criminal violence, described in full immediately below.

\section{Neurological Bases of Criminal Violence}

The foundation for using neuroimaging evidence in criminal trials-and for both the short- and long-term aims of the cognitive neuroscience project-lies in a massive (and growing) body of scientific literature on both the neuroanatomical ${ }^{140}$ and neurochemical ${ }^{141}$

because SPECT had not become "generally accepted" for that purpose); People v. Protsman, 105 Cal. Rptr. 2d 819, 822-23 (Ct. App. 2001) (barring PET scan evidence introduced to show lack of capacity to formulate intent for first-degree murder because relevant scientific community had "not generally accepted" use of PET to detect or evaluate longterm impact of brain traumas). But see People v. Erskine, 588 F.2d 721, 722 (9th Cir. 1978) (reversing lower court's exclusion of brain scan evidence in support of defendant's claim that he lacked capacity to formulate requisite specific intent to "influence action by [a] financial institution" through knowingly false statement or report); Martin Lasden, $M r$. Chiesa's Brain, CAL. LAw., Nov. 2004, at 26, 27-29 (reporting case of Peter J. Chiesa, who successfully introduced SPECT evidence to show diminished capacity and was convicted of second-degree murder even though prosecutor sought first-degree conviction).

137 E.g., People v. Weinstein, 591 N.Y.S.2d 715, 724 (Sup. Ct. 1992) (admitting PET scan showing arachnoid cyst in defendant's frontal lobe). According to newspaper reports, the Weinstein court's decision to admit the PET evidence motivated the prosecution to offer a favorable plea bargain. See Jeffrey Rosen, The Brain on the Stand, N.Y. TIMEs, Mar. 11, 2007, $\$ 6$ (Magazine), at 49 ("[T] he prosecution team seemed to fear that simply exhibiting images of Weinstein's brain in court would sway the jury."); $c f$. J. Rojas-Burke, PET Scans Advance as Tools in Insanity Defense, 34 J. NuCleAR MED. 13N, 26N (1993) ("[Weinstein's attorney] claims that the prosecutor would never have agreed to a plea if the judge had excluded the PET evidence."). For a further description of the neuroimaging evidence admitted in Weinstein, see Kulynych, supra note 25, at 1251.

138 Laura A. Kiernan, Hinckley Judge Reverses Himself, Admits Pictures of Defendant's Brain, WASH. PoSt, Jun. 2, 1982, at A3. Hinckley was found not guilty by reason of insanity.

139 See infra Part III.A.

140 That is, theories of violence focusing on the structure and function of the brain.

141 There are several studies that test hypotheses about the neurotransmitters that are thought to serve excitatory and inhibitory functions in this manner. For example, some researchers have examined the inhibitory effects of the neurotransmitter serotonin. E.g., Emil F. Coccaro et al., Impulsive Aggression in Personality Disorder Correlates with Tritiated Paroxetine Binding in the Platelet, 53 Archives Gen. Psychiatry 531 (1998). Others have examined the excitatory function of noradrenaline (also known as norepinephrine). 
bases for the various types of violence (i.e., reactive, instrumental, impulsive, and premeditated). ${ }^{142}$ In 1998 and 1999, an interdisciplinary group of experts were convened under the auspices of the Aspen Neurobehavioral Conference to create a consensus statement on the relationship between the mind, the brain, and violence. ${ }^{143}$ To this end, they conducted an exhaustive literature survey of the role of the brain in violent behavior and issued a statement in 2001 noting that the limbic system and the frontal lobes "are thought to play preeminent roles in [violent] behavior." 144 The statement asserted that:

Aggressive behavior has been thought to arise from the operations of the limbic system under certain circumstances, and the amygdala is the structure most often implicated. . . . [P]refrontal functions may ... provide an individual with the capacity to exercise judgment in the setting of complex social situations in which actions have significant consequences. In many cases, this capacity for judgment may serve the important function of inhibiting limbic impulses, which, if acted on, could be socially inappropriate or destructive. ... Therefore, there exists a balance between the potential for impulsive aggression mediated by temporolimbic structures and the control of this drive by the influence of the orbitofrontal regions. ${ }^{145}$

This theory of violence was informed, and has been reinforced by, neuroimaging studies. The first such study was published in 1994 by Adrian Raine, who used PET to illustrate diminished activity of the prefrontal cortex (PFC) of individuals accused of murder. ${ }^{146}$ In many of Raine's subsequent works, the PFC-limbic-system model of violence sketched out in the consensus statement figures prominently. ${ }^{147}$

E.g., Gilberto Gerra et al., Neurotransmitter-Neuroendocrine Responses to Experimentally Induced Aggression in Humans: Influence of Personality Variable, 66 PsychIATRY Res. 33 (1997).

142 See Mrigendra Das et al., Neuroimaging Violence in the Mentally Ill: What Can It Tell Us?, 63 Hosp. MED. 604, 606 (2002) (setting forth similar typology of violence and defining "reactive" as "response to frustration or threat," "instrumental" as "purposeful and goal directed," "impulsive" as "sudden, without planning," and "premeditated" as "planned").

143 Christopher M. Filley et al., Toward an Understanding of Violence: Neurobiological Aspects of Unwarranted Physical Aggression: Aspen Neurobehavioral Conference Consensus Statement, 14 Neuropsychiatry Neuropsychology \& Behav. Neurology 1,1 (2001).

144 Id. at 5.

145 Id.

146 Adrian Raine et al., Selective Reductions in Prefrontal Glucose Metabolism in Murderers, 36 Biological Psychiatry 365, 365-66, 370-71 (1994). Raine confirmed his findings in a paper published in 1997. Adrian Raine et al., Brain Abnormalities in Murderers Indicated by Positron Emission Tomography, 42 BIological. Psychiatry 495 (1997).

147 See, e.g., Adrian Raine et al., Prefrontal Glucose Deficits in Murderers Lacking Psychosocial Deprivation, 11 Neuropsychiatry Neuropsychology \& Behav. Neu. ROLOGY 1, 2 (1998) (examining whether "prefrontal dysfunction may specifically charac- 
Other articles surveying the neuroimaging literature similarly affirm the widespread association of prefrontal dysfunction and violence. ${ }^{148}$ Further literature reviews ${ }^{149}$ and articles written by prominent neuroscientists $^{150}$ have reached similar conclusions.

In addition to the iconic case of Phineas Gage, ${ }^{151}$ there are striking modern examples of the relationship between frontal lobe injuries (or dysfunction) and a disposition to criminal violence. For example, following a concussive injury to his prefrontal cortex, Louis Culpepper found himself no longer able to restrain his impulses to molest his five-year-old stepdaughter. ${ }^{152}$ In a similar case, following the development of an egg-sized tumor in his prefrontal lobe, a school teacher with no criminal record and a stable marriage found himself unable to restrain his impulses to view child pornography, solicit sex, and make sexual overtures to his stepdaughter. ${ }^{153}$ Once the tumor was removed, his inhibitions and capacity for self-restraint were restored. ${ }^{154}$ A more recent example is Andrew Laing, who lost all

terize violent offenders who lack psychosocial deficits"); Adrian Raine et al., Reduced Prefrontal and Increased Subcortical Brain Functioning Assessed Using Positron Emission Tomography in Predatory and Affective Murderers, 16 BeHav. SCl. \& L. 319, 321 (1998) (assessing "differences between affective and predatory murderers in cortical and subcortical brain functioning").

148 Following a 2005 review of seventeen neuroimaging studies of aggressive, violent, and antisocial patients, Jana L. Bufkin and Vickie R. Luttrell concluded that prefrontal dysfunction is "consistently related to aggressive and/or violent behavior," although "this association may reflect a predisposition only." Bufkin \& Luttrell, supra note 20, at 182. They also suggested that "reduced prefrontal functioning relative to subcortical functioning was characteristic of those who commit impulsive [but not predatory] acts of aggression and/or violence." Id. at 183.

149 See M.C. Brower \& B.H. Price, Neuropsychiatry of Frontal Lobe Dysfunction in Violent and Criminal Behaviour: A Critical Review, 71 J. Neurology Neurosurgery \& PSYCHIATRY 720, 722-23 (2001) (surveying eighteen neuroimaging or neuropsychological studies touching on frontal lobe dysfunction and violent behavior); Das et al., supra note 142 , at 607 (reviewing fourteen neuroimaging studies).

150 See, e.g., Richard L. Frierson \& Ryan D. Finkenbine, Psychiatric and Neurological Characteristics of Murder Defendants Referred for Pretrial Evaluation, 49 J. Forensic SCI. 604, 605 (2004) (discussing studies observing frontal lobe dysfunction in murderers); see also Ian Barkataki et al., A Neuropsychological Investigation into Violence and Mental Illness, 74 SCHIzOPHRENIA Res. 1, 9-11 (2005) (finding different cognitive impairments to have a neuropsychological basis in PFC dysfunction, manifested in antisocial personality disorder (APD) and schizophrenia); Richard J. Davidson et al., Dysfunction in the Neural Circuitry of Emotion Regulation-A Possible Prelude to Violence, 289 SCIENCE 591, 593-94 (2000) (positing that impulsive aggression and violence arise as consequence of faulty brain circuitry responsible for emotional regulation); Sapolsky, supra note 15, at 1789-90 (questioning M'Naughten rule of insanity in light of neuroscience evidence regarding consequences of PFC impairment).

151 See supra note 64 and accompanying text.

152 Jonathan Pincus, Base Instincts: What Makes Killers Kill? 15-19 (2001).

153 Thompson, supra note 16 , at 50-51.

154 Id. 
sexual inhibitions and sense of propriety following a concussive injury to his prefrontal lobe in a skiing accident. ${ }^{155}$

\section{Psychopathy and Antisocial Personality Disorder}

A significant and growing area of research on the disposition to criminal violence concerns the neurobiological correlates of psychopathy and antisocial personality disorder (APD). ${ }^{156}$ Psychopathy is defined as "a cluster of personality traits including manipulativeness, lack of empathy, and impulsivity." 157 As noted in an amicus brief filed by the American Psychological Association (APA) in Roper $v$. Simmons, ${ }^{158}$ "psychopathy is presumed to be deep seated, stable over time, and resistant, if not absolutely impervious, to change."159 APD

155 See Becky Sheaves, The Freak Accident that Left My Son Obsessed with Sex, DAILY MAIL (London), July 4, 2006, at 49 (describing Laing's aggressive and bizarre behavior, sexual risk-taking, and inability to understand social cues or body language after damage to frontal lobe).

156 Regardless of whether neuroscience evidence is used at trial, APD and psychopathy diagnoses are often used by the prosecution to argue that a capital defendant presents a future danger. See infra Part III.B.

157 John Monahan, A Jurisprudence of Risk Assessment: Forecasting Harm Among Prisoners, Predators, and Patients, 92 VA. L. REV. 391, 421 (2006). The first American study of psychopathy was undertaken in 1941, culminating in Hervey Cleckley, ThE MASK of Sanity: An Attempt to Clarify Some Issues About the So-Called Psychopathic Personality (3d ed. 1955). The term "sociopathy" was introduced by G.E. Partridge in his 1930 work, Current Conceptions of Psychopathic Personality, 10 AM. J. PsychiATry 53, 55 (1930). Other early expressions for psychopathy included "mania without delerium" and "moral insanity." See Philippe Pinel, A Treatise on Insanity ix (D.D. Davis trans., Hafner Publ'g photo. reprint 1962) (1806); James Cowles Prichard, A Treatise on Insanity and Other Disorders Affecting the Mind vii (London, Sherwood, Gilbert \& Piper 1835).

158543 U.S. 551 (2005).

159 Brief for the American Psychological Ass'n \& the Missouri Psychological Ass'n as Amici Curiae Supporting Respondent at 20, Roper v. Simmons, 543 U.S. 551 (2006) (No. 03-633) [hereinafter APA Brief]. The brief argues that psychopathy

is an adult personality feature defined chiefly by a combination of antisocial behavior, callousness, and emotional detachment. Psychopaths have been described as "[l]acking in conscience and in feeling for others, [and] . . coldbloodedly tak[ing] what they want and do[ing] what they please, violating social norms and expectations without the slightest sense of guilt or regret."

Unlike disorders such as depression, psychopathy is presumed to be deep seated, stable over time, and resistant, if not absolutely impervious, to change. Some experts have gone so far as to conclude that "at this time there is no empirical evidence to suggest that psychopathy is treatable." As a group, psychopaths "are responsible for a markedly disproportionate amount of the serious crime, violence and social distress in every society." . .

Evidence of psychopathy can strongly encourage the imposition of the death penalty in a particular case. Indeed, some of the cases which have shaped the Court's death sentencing jurisprudence have centered on evidence of psychopathic tendencies.

Id. at 20-21 (alterations in original) (internal citations omitted). But see Mark D. Cunningham \& Thomas J. Reidy, Antisocial Personality Disorder and Psychopathy: Diag. 
is a related diagnostic construct of the DSM-IV that is based on behavioral characteristics such as "a pervasive pattern of disregard for, and violation of, the rights of others that begins in childhood or early adolescence and continues into adulthood."160

A recent literature survey reviewed five structural and fifteen functional neuroimaging studies relating to APD and psychopathy that were published in the last decade. ${ }^{161}$ While careful to note the difficulties in comparing such studies, ${ }^{162}$ the paper tentatively concluded that " $[\mathrm{t}]$ he functional but not the structural neuroimaging [studies] strongly suggest dysfunction of the frontal and temporal lobes, and possibly other structures including the angular gyrus and corpus callosum, in psychopathy. However, replication studies are required before conclusions can be drawn."163 In other words, the structural studies of the brain were inconclusive, whereas the functional studies revealed a striking connection between abnormal brain activity and psychopathy (though more study is needed before this can be confirmed).

In addition to his work on the neurological bases of violence, Adrian Raine is also responsible for the first article showing a struc-

nostic Dilemmas in Classifying Patterns of Antisocial Behavior in Sentencing Evaluations, 16 Behav. SCI. \& L. 333, 345-46 (1998) (noting that "treatment intervention studies with psychopaths are sparse and contradictory" but observing that effectiveness of treatment is not promising for severe psychopaths).

160 DSM-IV, supra note 120 , at 645 . For an in-depth discussion of the diagnostic criteria for APD, see John H. Blume \& David P. Voisin, Capital Cases, 24 ChamPIon 69, 70-73 (2000). It has been observed that there is a strong correlation between psychopathy and APD; one study found that $87.7 \%$ of inmates diagnosed with psychopathy (defined as a score of above 30 on the Psychopathy Checklist Revised (PCL-R)) also satisfied the criteria for APD. Cunningham \& Reidy, supra note 159, at 341 . Nevertheless, some prominent experts in the field of risk assessment have cautioned against equating psychopathy and APD, noting that the two conditions reflect different criteria. See, e.g., Robert D. Hare, Psychopathy and Antisocial Personality Disorder: A Case of Diagnostic Confusion, 13 PsyChIATRIC TIMEs 39 (1996) (noting that distinction between psychopathy and APD often is blurred). Hare, who developed the PCL-R, the most effective psychopathy risk assessment instrument, argues that while psychopathy is highly predictive of recidivist violence, a diagnosis of APD is much less reliable. Id. Cunningham and Reidy agree, arguing that "APD has not demonstrated satisfactory performance as a predictor of criminality, institutional violence, and violent recidivism ...." Cunningham \& Reidy, supra note 159, at 347.

161 Saxby Pridmore et al., Neuroimaging in Psychopathy, 39 AustL. \& N.Z. J. PsyCHIATRY 856 (2005).

162 Pridmore and his coauthors noted that comparative difficulties arose from differences in methods used among the studies reviewed, as well as from problems in selecting homogeneous index cases and appropriate control groups. Id. at 862-63. For these reasons, the paper does not offer conclusions as to the five structural studies. Id.

163 Id. at 863. 
tural brain deficit in subjects with APD. ${ }^{164}$ Based on his research, Raine tentatively concluded that this structural deficit "may underlie the low arousal, poor fear conditioning, lack of conscience, and decision-making deficits that have been found to characterize antisocial, psychopathic behavior." $165 \mathrm{He}$ has also found abnormally high white matter volume in the corpus callosa (the band of tissue connecting the left and right hemispheres of the brain) of "psychopathic antisocial individuals" (as measured by the Psychopathy Checklist Revised (PCL-R)). ${ }^{166}$ Raine has speculated that this abnormality might impair interhemispheric communication in a way that bears on the affective deficits typical of psychopaths. ${ }^{167}$

Many other prominent neuroscientists likewise have undertaken inquiries using neuroimaging tools to explore the potential connection between brain abnormalities and violence. ${ }^{168}$ By linking brain abnor-

164 Adrian Raine et al., Reduced Prefrontal Gray Matter Volume and Reduced Autonomic Activity in Antisocial Personality Disorder, 57 Archives Gen. Psychiatry 119, 125 (2000) (noting eleven-percent reduction in gray matter in prefrontal cortex of subjects with APD).

165 Id. at 119.

166 Adrian Raine et al., Corpus Callosum Abnormalities in Psychopathic Antisocial Individuals, 60 Archives Gen. Psychiatry 1134, 1135, 1137, 1138 tbl.2 (2003).

167 Id. at 1134. Similarly, Raine has published articles identifying, for the first time, structural brain abnormalities in a particular subcategory of psychopath (psychopaths who are considered "unsuccessful" because they were not able to avoid capture and prosecution by law enforcement). Adrian Raine et al., Hippocampal Structural Asymmetry in Unsuccessful Psychopaths, 55 Biological Psychiatry 185 (2004); Yaling Yang, Adrian Raine et al., Volume Reduction in Prefrontal Gray Matter in Unsuccessful Criminal Psychopaths, 57 Biological Psychiatry 1103 (2005). In addition, Raine has numerous other publications exploring the relationship between psychopathy (or APD) and the structure and function of the brain. E.g., Adrian Raine, Psychopathy, Violence, and Brain Imaging, in Violence and Psychopathy 35, 35-57 (Adrian Raine \& José Sanmartín eds., 2001).

168 E.g., Antoine Bechara et al., Insensitivity to Future Consequences Following Damage to Human Prefrontal Cortex, 50 Cognition 7, 8 (1994) (demonstrating connection between prefrontal lobe damage and impaired decisionmaking through neuropsychological testing); R. James R. Blair, Editorial, Neurobiological Basis of Psychopathy, 182 BRIT. J. Psychiatry 5 (2003) (discussing neuroimaging studies finding association between amygdala dysfunction and psychopathy and noting probable impairment of orbitofrontal cortex in psychopathic individuals); R.J.R. Blair, Neurocognitive Models of Aggression, the Antisocial Personality Disorders, and Psychopathy, 71 J. Neurology Neurosurgery \& PsyCHIATRY 727 (2001) (discussing neurocognitive models of aggression and relating them to explanations of APD); Antonio R. Damasio, A Neural Basis for Sociopathy, 57 ArCHIves GEN. PSYChIATRY 128, 128-29 (2000) (noting that Raine's paper on reduction in prefrontal white matter volume in psychopaths, Raine et al., supra note 164 , bolsters hypothesis that "the symptoms of developmental sociopathic individuals are related to the malfunction of neural systems, which include critical components in the prefrontal cortex"); Kent A. Kiehl et al., Limbic Abnormalities in Affective Processing by Criminal Psychopaths as Revealed by Functional Magnetic Resonance Imaging, 50 Biological PsychiatRy 677 (2001) (working with PCL-R creator Hare to use fMRI to examine correlation between affective processing anomalies typically found in criminal psychopaths and deficient input from limbic structures). 
malities to specific behaviors-and, specifically, to violent behaviorthese studies provide a foundation for the use of neuroimaging evidence in criminal trials.

II

The Aspirations of Cognitive Neuroscience for Capital Sentencing

\section{A. Short-Term Aim: Aiding Capital Defendants}

The short-term aim of cognitive neuroscientists for capital sentencing is straightforward. Their goal is to bolster defendants' mitigation claims with cutting-edge neuroimaging research that demonstrates a biological disposition to criminal violence. To elaborate the contours of this short-term project, this section first provides a very cursory sketch of the capital sentencing process and locates the efforts of cognitive neuroscientists within this framework. Next, the section briefly introduces the general approaches used by neuroscientists to assist capital defendants. Third, it uses the recent case of Roper $v$. Simmons as a point of departure to illustrate the methodology and strategies of cognitive neuroscientists in this field. Part II.A concludes with an appraisal of the success of the short-term aspirations to date, measured both by the rate of success at getting neuroimaging evidence before capital juries at sentencing and by the ultimate persuasive force of such evidence.

To fully appreciate the short-term aims of cognitive neuroscientists for capital sentencing, it is necessary first to understand the procedural context in which these aims are pursued. While the precise procedures vary from state to state, virtually all capital sentencing regimes direct the jury to evaluate mitigating ${ }^{169}$ and aggravating ${ }^{170}$ factors in considering whether to impose the death penalty. ${ }^{171}$ The

169 See, e.g., KAN. STAT. ANN. § 21-4626 (Supp. 2006) (listing several common statutory mitigating factors, such as lack of prior criminal history, minor or accomplice role in crime commited by another, "the influence of extreme mental or emotional disturbances," and when defendant's capacity "to appreciate the criminality of [his] conduct or to conform [his] conduct to the requirements of the law was substantially impaired").

170 See, e.g., Ring v. Arizona, 536 U.S. 584, 592-93 \& n.1 (2002) (listing statutory aggravating factors, including prior conviction for "serious offense," commission of offense for "anything of pecuniary value," and commission of offense "in an especially heinous, cruel or depraved manner") (citing ARIz. Rev. STAT. ANN. § 13-703(F) (2001)); Jonathan Simon \& Christina Spaulding, Tokens of Our Esteem: Aggravating Factors in the Era of Deregulated Death Penalties, in The Killing State: Capital Punishment in Law, Politics, AND Culture 81, 91 tbl.4.2 (Austin Sarat ed., 1999) (listing aggravating factors in various states).

171 See Kansas v. Marsh, 126 S. Ct. 2516, 2524-25 (2006) (noting that states may weigh aggravating and mitigating factors as they please, provided they observe fundamental principles of Supreme Court's Eighth Amendment jurisprudence that all capital sentencing 
consideration of mitigating evidence is central to the constitutional requirement of individualized sentencing. ${ }^{172}$ The Supreme Court has held that defendants enjoy wide latitude in their presentation of mitigating evidence bearing on "any aspect of [the] defendant's character or record and any of the circumstances of the offense that the defendant proffers as a basis for a sentence less than death."173 It is typical for defense experts to testify about the mitigating effects of mental illness or brain damage in an attempt to persuade jurors that a defendant is less than fully culpable and should receive a sentence of life imprisonment rather than death. ${ }^{174}$ It is within this procedural framework that cognitive neuroscientists have sought to wield their tools on behalf of defendants facing the death penalty.

Reported cases ${ }^{175}$ and public commentary ${ }^{176}$ demonstrate that cognitive neuroscientists are increasingly contributing to the mitiga-

schemes must "(1) rationally narrow the class of death-eligible defendants; and (2) permit a jury to render a reasoned, individualized sentencing determination based on a deatheligible defendant's record, personal characteristics, and the circumstances of his crime"). For a discussion of different approaches to comparing aggravating and mitigating factors, see James R. Acker \& Charles S. Lanier, Matters of Life or Death: The Sentencing Provisions in Capital Punishment Statutes, 31 CrIM. L. Bull. 19, 33-52 (1995).

172 See Marsh, $126 \mathrm{~S}$. Ct. at 2525 (describing role of mitigating evidence in allowing sentencer to evaluate defendant as individual, as required by Eighth and Fourteenth Amendments).

173 Id. (quoting Lockett v. Ohio, 438 U.S. 586, 604 (1978)) (internal quotation marks omitted).

174 See Frierson \& Finkenbine, supra note 150, at 604 ("In death penalty cases a history of mental illness or organic brain impairment is frequently used by the defense for the purpose of mitigation ...."); Dorothy Otnow Lewis et al., Ethics Questions Raised by the Neuropsychiatric, Neuropsychological, Educational, Developmental, and Family Characteristics of 18 Juveniles Awaiting Execution in Texas, 32 J. Am. ACAD. Psychiatry \& L. 408, 427 (2004) (arguing that results of neurological evaluations would be relevant to mitigation, if not culpability, for violent juvenile offenders); Ellen Fels Berkman, Note, Mental Illness as an Aggravating Circumstance in Capital Sentencing, 89 ColuM. L. Rev. 291, 298 (1989) (describing research showing that many death row inmates are mentally ill).

175 See, e.g., People v. Kraft, 5 P.3d 68, 98 (Cal. 2000) (describing introduction of PET scan as mitigating evidence showing defendant's brain abnormalities); People v. Holt, 937 P.2d 213, 231 (Cal. 1997) (admitting PET and EEG scans as part of mitigation claim); Rogers v. State, 783 So. 2d 980, 998-99 (Fla. 2001) (upholding trial court's grant of funds for MRI scan, but not PET scan, for defendant's mitigation case); Robinson v. State, 761 So. 2d 269, 275 (Fla. 1999) (affirming trial court's denial of defendant's request to admit SPECT scan for use in mitigation case); Hoskins v. State, 735 So. 2d 1281, 1281 (Fla. 1999) (vacating death sentence for trial court's failure to allow PET scan as mitigating evidence); People v. Jones, 620 N.Y.S.2d 656, 657-58 (App. Div. 1994) (reversing trial court's refusal to admit neuroscience evidence as part of mitigation case); Ex parte Simpson, 136 S.W.3d 660, 665 (Tex. Crim. App. 2004) (describing introduction of EEG and MRI evidence to support claim of mental retardation); Steve Emmons, Hunting for Brain Disorders, Attorneys Turn to UCI Scanner as Defense Tool, L.A. TimEs, July 14, 1989, § 2, at 1 (describing case of Ramon Salcido, who introduced PET scan evidence as part of his mitigation case).

176 See, e.g., The Neurobiology of Criminal Behavior (Joseph Glicksohn ed., 2002) (compiling neuroscience research on criminal behavior); PINCUs, supra note 152, at 
tion efforts of capital defendants. A significant group of neuroimaging experts has aided capital defendants in constructing their mitigation cases, testifying and using SPECT ${ }^{177}$ and PET ${ }^{178}$ scans on the behalf of defendants at trial. Some experts have also con-

35 (noting that "many [criminal] defense attorneys" are interested in finding possible neurological "abnormalities that could mitigate the death sentences of their clients"); Allison Abbott, Into the Mind of a Killer, 410 Nature 296 (2001) (describing debate over use of neuroscience in criminal justice system); James J. Clark et al., The Fiend Unmasked: Developing the Mental Health Dimensions of the Defense, CRIM. JusT., Summer 1993, at 22,23 (describing ways in which defense attorneys litigating on behalf of "troubled client[s]" can benefit from using mental health consultants); Das et al., supra note 142, at 604-05 (arguing that findings in neuroimaging will have broad social ramifications); Robert L. Denney, Criminal Responsibility and Other Forensic Issues, in Forensic NeuroPSYCHOLOGY: A SCIENTIFIC APPROACH 425, 445-52 (Glenn J. Larrabee ed., 2005) (discussing role of neuropsychologists in death penalty cases); Lasden, supra note 136, at 30 , 61-62 (offering examples of use of neuroscience testimony in death penalty cases); R.K. McKinzey, A Judge's Introduction to Neuropsychological Assessments, CourT REv., Winter 2001, at 24 (providing attorneys with expert advice regarding possible brain damage in clients charged with capital offenses); Alison Motluk, Not Guilty, New Scientist, May 13, 2000, at 42, 44-45 (noting support among neuroscientists for use of neuroimaging evidence in assessing degree of criminal responsibility); Adrian Raine, Murderous Minds: Can We See the Mark of Cain?, 1 Cerebrum 15, 16 (1999) ("Because California has the death penalty, [defendants] will die unless mitigating circumstances such as an abnormal PET scan revealing brain abnormalities can be found."); Jesse A. Seiden, The Criminal Brain: Frontal Lobe Dysfunction Evidence in Capital Proceedings, 16 CAP. DEF. J. 395, 397 (2004) (discussing "effect of frontal lobe dysfunction on behavior and the most effective use of such evidence in a capital murder case"); Thompson, supra note 16, at 51 (describing debate over relationship between brain structure and control over actions, including "moral and legal choices"); Judy Foreman, Brain Scans Draw a Dark Image of the Violent Mind, Boston Globe, Mar. 26, 2002, at B9 (describing research on link between brain structure and predisposition towards violence); Laura Mansnerus, Damaged Brains and the Death Penalty, N.Y. Times, July 21, 2001, at B9 ("[L]egal scholars say new findings on brain dysfunction are finally gaining attention ... in death penalty cases."); Michael McGough, My Brain Made Me Do It: What Happens to Guilt and Innocence When an MRI Can Tell You Who Is Likely to Commit a Violent Crime?, Pittsburgh Post-Gazette, June 6,2006 , at B7 (discussing questions raised by neuroscience research about traditional notions of culpability); Suzy Hansen, The Mind of a Killer, SAlon.COM, July 27, 2001, http://archive.salon.com/books/int/2001/07/27/killers/index2.html (interviewing neuroscientist Jonathan Pincus regarding link between violence and neurological damage).

177 One such expert is Dr. Daniel Amen, who regularly testifies in capital trials using SPECT scans of the defendant's brain as an adjunct to his testimony. Lasden, supra note 136, at 28.

178 Joseph Wu, Clinical Director of the University of California-Irvine Brain Imaging Center, uses PET scans in his work on behalf of defendants in murder trials. Id. at 29. One judge pejoratively referred to $\mathrm{Wu}$ as a "hired gun anxious to make the PET scan the instrument of truth." Id. at 61 (citing Jackson v. Calderon, No. CV 91-4249-R, 1997 WL 855516 , at $* 73$ (C.D. Cal. Nov. 14, 1997)). Wu trained under Monte Buchsbaum, who pioneered the use of PET scanning in capital defense work in the mid-1980s. Id. Since then, Buchsbaum has testified in numerous criminal trials (including many capital sentencing hearings), invoking PET scan evidence for purposes of mitigation. See Monte Buchsbaum, Use and Admissibility of Positron Emission Tomography (PET) Scanning in Head Injury, Presentation at the Judicial Seminar on Emerging Issues in Neuroscience Conference 27 (June 29, 2006), available at http://www.ncsconline.org/d_research/stl/June06/Buchsbaum. 
ducted studies that dovetail with the needs of capital defendants. For example, Raine and Monte Buchsbaum were coauthors of the first PET-scan-based study of the brain function of murderers. ${ }^{179}$ Raine has gone on to eloquently defend the use of his research as a mechanism for persuading juries (and society more broadly) that capital defendants should receive life sentences rather than the death penalty. ${ }^{180}$ Numerous other neuroimaging practitioners work on behalf of defendants at the sentencing phase of capital trials, using EEGs, QEEGs, and other methods to supplement their own testimony. ${ }^{181}$ Other cognitive neuroscientists who have not personally testified in capital trials have expressed support for the use of neuroscience testimony in this and related contexts. ${ }^{182}$

What kinds of mitigation claims do cognitive neuroscientists (and other practitioners of neuroimaging) make on behalf of capital defendants? What kinds of research do they invoke? In short, they argue that, although it does not provide an excuse for purposes of legal guilt, dysfunction in the violence-inhibitory mechanisms of a defendant's brain sufficiently diminishes his moral responsibility such that he deserves a sentence of life imprisonment rather than death. In support of these claims, such experts invoke cutting-edge neuroimaging research on the biological correlates of criminal violence. ${ }^{183}$

Roper $v$. Simmons, perhaps the most high-profile example of neuroimaging in the capital context, provides a useful example of precisely how cognitive neuroscientists invoke the growing body of research on criminal violence and the brain on behalf of capital defen-

ppt (noting types of mitigative evidence); see also Lasden, supra note 136, at 30 (describing work of Adrian Raine in testifying for defense in capital trials using PET scan evidence).

179 Raine et al., supra note 146.

180 Adrian Raine, The Psychopathology of Crime: Criminal Behavior as a Clinical Disorder 312 (1993) ("If we accept crime is a disorder ... then the implication is that criminal offenders should not be punished as severely as they are currently for their actions."); see also Motluk, supra note 176, at 45 (interviewing Raine and noting his statement that "I think we have to think twice about whether we execute these people"); Raine, supra note 176, at 25-26 (questioning whether brain-damaged murderers deserve to lose their lives "given the demonstrable constraints on [their] free will"); Sue Lindsay, Rape, Slaying Suspect Was Beaten as Child, His Grandmother Testifies, Rocky Mountain News (Denver), Nov. 10, 2000, at 22A (describing testimony of Raine in capital murder trial of defendant beaten and shaken as child).

181 See, e.g., Jacobs v. Horn, 395 F.3d 92, 101-02 (3d Cir. 2005) (admitting testimony of neuroscientist Dr. Patricia Fleming on behalf of capital defendant); Johnston v. State, 841 Sc. 2d 349, 353-54 (Fla. 2002) (describing testimony of neuropsychiatrist who performed EEGs and QEEG "[b]rain map" in connection with mitigation case); Mansnerus, supra note 176 (describing work of Dr. Jonathan Pincus, who uses "EEG's and brain scans" as part of mitigation work on behalf of capital defendants).

182 See, e.g., Sapolsky, supra note 15, at 1788 ("Arguably, the most important arena in which a greater knowledge of neuroscience is needed is the criminal justice system.").

183 For a fuller description of these biological correlates, see supra Part I.D. 
dants. In Roper, the Supreme Court entertained a challenge-under the Eighth Amendment's injunction against cruel and unusual punishment ${ }^{184}$ - to a state law permitting the execution of juveniles who were under the age of eighteen at the time they committed a capital offense. Among the numerous amicus briefs submitted, ${ }^{185}$ two in particular-one led by the American Psychological Association (APA) ${ }^{186}$ and one led by the American Medical Association (AMA) ${ }^{187}$-captured the public's imagination. Both made novel use of neuroimaging-based evidence to anchor their arguments that adolescents were categorically less morally blameworthy than adults and, as a result, not deserving of the ultimate criminal sanction of death. ${ }^{188}$

According to the briefs, neuroimaging research suggests that adolescents' behavioral immaturity is due, in large measure, to the "anatomical immaturity of their brains." 189 The briefs cite structural and functional neuroimaging studies showing that the neocortical regions of the brain, which are believed to be responsible for risk assessment, impulse control, and high-level cognition, are not yet fully developed in adolescents. ${ }^{190}$ Conversely, those subcortical areas of the brain from which impulsivity and violence are thought to arise are fully developed in adolescents and, indeed, are more active in teenagers than in adults. ${ }^{191}$ Specifically, the AMA brief points to research showing that the limbic system - the amygdala in particular-is overactive in the brains of adolescents. ${ }^{192}$ This part of the brain is associ-

184 U.S. CONST, amend. VIII.

185 See American Bar Association, Juvenile Death Penalty Amicus Briefs, http://www. abanet.org/crimjust/juvjus/simmons/simmonsamicus (last visited July 28, 2007) (listing and linking to amicus briefs filed on behalf of both Petitioner and Respondent in Roper v. Simmons, 543 U.S. 551 (2005)).

186 APA Brief, supra note 159.

187 Brief for the American Medical Ass'n et al. as Amici Curiae Supporting Respondent, Roper, 543 U.S. 551 (No. 03-633) [hereinafter AMA Brief]. Cosigners included the American Psychiatric Association, the American Society for Adolescent Psychiatry, the American Academy of Child \& Adolescent Psychiatry, the American Academy of Psychiatry and the Law, the National Association of Social Workers, the Missouri Chapter of the National Association of Social Workers, and the National Mental Health Association. Id . at 1.

188 Id. at 3-4; APA Brief, supra note 159, at 9 . The briefs also pointed to other social science evidence in support of their theses that adolescents are categorically less culpable than adults. AMA Brief, supra note 187, at 4-9; APA Brief, supra note 159, at 4-9.

189 AMA Brief, supra note 187, at 10; accord APA Brief, supra note 159, at 9 (suggesting "biological dimension to adolescent behavioral immaturity").

190 AMA Brief, supra note 187, at 11; APA Brief, supra note 159, at 10.

191 AMA Brief, supra note 187 , at 11.

192 Id. at 15 \& n.52 (citing Frontline: Inside the Teenage Brain (PBS television broadcast Jan. 31, 2002) (interviewing Deborah Yurgelun-Todd, Director of Neuropsychology and Cognitive Neuroimaging, McLean Hospital, Belmont, Mass.); K. Rubia et al., Functional 
ated with "primitive impulses of aggression, anger and fear."193 At the same time, the frontal lobes-and particularly the prefrontal cortex - which are "the regions of the brain associated with impulse control, risk assessment, and moral reasoning,"194 are still developing in adolescents and are insufficiently mature to mediate and check the influence of the limbic system. ${ }^{195}$

Both the AMA and APA amicus briefs also cite neuroimaging studies showing that the adolescent prefrontal cortex has not yet completed two important processes necessary to its full function: myelination and pruning. ${ }^{196}$ "Myelination" is the process by which the axons ("neural fibers that use electrical impulses to carry information across long distances") ${ }^{197}$ are insulated, strengthening and reinforcing their connections and "thereby greatly speeding up the communication between cells, allowing the brain to process information more efficiently and reliably." 198 "Pruning" is the process by which the volume of the brain's gray matter (composed of neurons) is thinned, thus strengthening the connections among the neurons that remain and improving their function. ${ }^{199}$ Studies suggest that late in childhood there is a new proliferation of gray matter in the prefrontal cortex, which is then gradually pruned in a process that does not conclude until after adolescence. ${ }^{200}$

The APA brief includes an extensive argument that the exclusion of adolescents from capital punishment should be categorical because, given adolescents' unfixed personal characteristics due in large part to their still-developing brains, the mechanisms of capital sentencing are not sufficient to assess their individual culpability. ${ }^{201}$ Capital jurors

Frontalisation with Age: Mapping Neurodevelopmental Trajectories with fMRI, 24 Neuroscience \& Biobehavioral Reviews 13 (2000)).

193 Id. at 11.

194 Id.

195 Id. at 16-20 (citing Nitin Gogtay et al., Dynamic Mapping of Human Cortical Development During Childhood Through Early Adulthood, 101 Proc. Nat'L ACAD. ScI. 8174, 8174 (2004) (showing delayed development of frontal lobes)); APA Brief, supra note 159, at 9-12; see also Jay N. Giedd et al., Brain Development During Childhood and Adolescence: A Longitudinal Study, 2 Nature Neuroscience 861, 861 (1999) (showing delayed development of frontal lobes); Elizabeth R. Sowell et al., In Vivo Evidence for Post-Adolescent Brain Maturation, 2 Nature Neuroscience 859, 860 (1999) (same).

196 AMA Brief, supra note 187, at 17-20; APA Brief, supra note 159, at 10-11.

197 AMA Brief, supra note 187 , at 17.

198 APA Brief, supra note 159, at 11; accord AMA Brief, supra note 187, at 17 ("The presence of myelin makes communication between different parts of the brain faster and more reliable.").

199 AMA Brief, supra note 187, at 18-19; APA Brief, supra note 159, at 10-11.

200 AMA Brief, supra note 187, at 19-20; APA Brief, supra note 159, at 10.

201 APA Brief, supra note 159, at 15-26. In addition to the AMA and APA amicus briefs, a coalition of juvenile justice advocates submitted a brief signed by more than fifty 
are thus incapable of accurately weighing the relevant aggravating and mitigating factors in the balancing process required by virtually every jurisdiction that retains the death penalty.

The APA and AMA briefs appeared to have an impact on the Court's consideration of Roper. ${ }^{202}$ At oral argument, sixteen of the twenty questions asked of then-Solicitor General Seth Waxman (arguing on behalf of the Government) concerned the scientific evidence presented in the two briefs. ${ }^{203}$ Moreover, in the opinion itselfwhich affirmed the Missouri Supreme Court's conclusion that applying the death penalty to juveniles runs afoul of the Eighth Amendment ${ }^{204}$ - the Court's reasoning seemed animated by arguments raised in the briefs. In the majority opinion, Justice Kennedy observed:

Three general differences between juveniles under 18 and adults demonstrate that juvenile offenders cannot with reliability be classified among the worst offenders. First, as any parent knows and as

such organizations. Brief for the Juvenile Law Center et al. as Amicus Curiae Supporting Respondent at app. A, Roper v. Simmons, 543 U.S. 551 (2005) (No. 03-633) [hereinafter JLC Brief]. The brief included a petition entitled "Health Professionals' Call to Abolish the Execution of Juvenile Offenders in the United States." Id. at app. C; see also Press Release, Physicians for Human Rights, Former U.S. Surgeons General and More Than 400 Child Health Professionals Call for an End to the Juvenile Death Penalty (July 19, 2004), available at http://physiciansforhumanrights.org/library/news-2004-07-19.html (describing petition). The petition declared that:

Neuroscience provides physiological evidence of adolescents' under-developed mental capacities. Established principles and cutting-edge neuroscientific research together demonstrate that adolescent behavior is dominated by the region of the brain associated with impulse control and aggression (the amygdala). The prefrontal cortex, which controls such impulse and aggression, and which permits anticipation of consequences, consideration of alternatives, planning, setting long range goals, and organization of sequential behavior, does not fully mature until well beyond age eighteen (possibly as late as age twenty-three). Leading neuroscientists have observed, therefore, that it is unfair and unreasonable to impose expectations of adult-level capacities on the thinking and behavior of minors.

JLC Brief, supra, at app. C at C2. The petition was signed by over four hundred health care professionals, including former Surgeons General C. Everett Koop (1981-89) and Julius Richmond (1977-81). Id . at app. C at C5-C6. The petition was also signed by a wide array of neuroscientists, neurologists, psychiatrists, and psychologists. See id. at app. $\mathrm{C}$ at C4-C42 (listing seven "Selected Endorsers" and thirty "Endorsers" with expertise in neuroscience and neuroimaging).

202 Aliya Haider, Roper v. Simmons: The Role of the Science Brief, 3 OHIO ST. J. Crim. L. 369,375 (2006). But see Morse, supra note 24, at 410 (noting that Roper majority did not cite specifically to any neuroimaging studies relied on by amicus briefs).

203 Haider, supra note 202, at 375.

204 The U.S. Supreme Court concluded by a vote of 5-4 that: (1) there was a national consensus against the juvenile death penalty, and (2) as a normative matter, the juvenile death penalty was contrary to the evolving Eighth Amendment standards that mark the progress of a maturing society. Roper, 543 U.S. at 561-67. 
the scientific and sociological studies respondent and his amici cite tend to confirm, "[a] lack of maturity and an underdeveloped sense of responsibility are found in youth more often than in adults and are more understandable among the young. These qualities often result in impetuous and ill-considered actions and decisions." 205

Justice Kennedy agreed with the briefs' arguments that, because adolescents have a temporarily diminished capacity for sound decisionmaking and personal restraint, sentencing them to death violates the basic principles of retributive justice on which capital punishment is grounded. ${ }^{206}$ Justice Kennedy reasoned that juveniles are less blameworthy principally because their disposition to criminal violence is due to "transient immaturity" rather than "irreparable corruption." 207 The risk that jurors might mistake the former (a mitigating circumstance) for the latter (an aggravating circumstance) makes the individualized sentencing required by the Eighth Amendment impossible when the offender is a juvenile.

The neurobiological theory of violence set forth by the Roper amici-with its focus on frontal lobe impairment-fairly represents the capital mitigation arguments used by cognitive neuroscientists generally. ${ }^{208}$ Neuroscientist Michael Gazzaniga has noted that those who represent criminal defendants "are looking for that one pixel in

$205 I d$. at 569 (quoting Johnson v. Texas, 509 U.S. 350, 367 (1993)). The other two differences cited by Justice Kennedy were juveniles' vulnerability to negative influences and peer pressure, and their unformed and transitory character. Id. at 569-70. Presumably, the "scientific" studies referenced above include the neuroimaging studies cited by the AMA and the APA in their briefs.

206 Id. at 571.

207 Id. at 573.

208 Many cognitive neuroscientists have focused on frontal lobe impairment. For example, Raine has argued both in court and in the public square that his neuroimaging research on violence and the brain (and frontal lobe dysfunction in particular) strongly suggests that defendants exhibiting such disorders should not be executed. Motluk, supra note 176, at 45 (interviewing Raine); Raine, supra note 176, at 29 ("Will we look back aghast at the execution of seriously violent offenders? Will we view execution of prisoners as we now view the burning of witches? I would like to think so . ..."). More recently, psychologist and law professor Richard Redding has argued that the insanity defense should be modified to take account of the difficulty that those suffering from frontal lobe disorders face in conforming their behavior to the relevant legal standards in spite of their rational understanding of the antisocial nature of their actions. Richard $\mathrm{E}$. Redding, The Brain-Disordered Defendant: Neuroscience and Legal Insanity in the Twenty-first Century, 56 Ам. U. L. Rev. 51, 53 (2006). Neurologist Jonathan Pincus and psychiatrist Dorothy Otnow-Lewis-both iconic figures in the world of capital defense mitigation work-regularly evaluate defendants for frontal lobe impairment. Malcolm Gladwell, Damaged: Why Do Some People Turn into Violent Criminals? New Evidence Suggests That It May All Be in the Brain, New Yorker, Feb. 24 \& Mar. 3, 1997, at 132, 133. Legal practitioners have also taken notice. A 2004 article in the Capital Defense Journal similarly argues that "[f]rontal lobe dysfunction is ripe for consideration . . . as strong mitigation evidence during sentencing." Seiden, supra note 176 , at 420. 
their client's brain scan that shows . . . a malfunction in the normal inhibitory networks," which would allow them to demand leniency on the grounds that their client could not control his actions. ${ }^{209}$ Capital defense attorneys, encouraged by some successes, ${ }^{210}$ now present evidence of frontal lobe dysfunction as mitigation evidence during the sentencing phase; a growing body of scholarly literature encourages the use of such evidence. ${ }^{211}$

How has the short-term aim of cognitive neuroscientists fared to date? In terms of persuading courts to admit neuroimaging evidence, it can be regarded as successful. Indeed, some courts have even held that the failure to allow neuroimaging evidence to be introduced at the sentencing phase of a trial constitutes reversible error. ${ }^{212}$ At least one court has granted a defendant funds to conduct neuroimaging during a capital trial. ${ }^{213}$ But this is not so surprising; as noted above, courts can be very permissive when it comes to admitting evidence for purposes of capital mitigation. ${ }^{214}$ By the metric of whether defendants receive a life sentence or the death penalty, however, the project has proven to not be as successful. There are many cases in which

209 Thompson, supra note 16 , at 52-53. Thompson concludes that neuroscientists should embrace such a role so that criminals might be punished "better." Id. at 53.

210 Redding has noted approvingly that neuroscientific research on frontal lobe dysfunction "is actually having an effect on real-life cases" as judges increasingly are willing to fault defense attorneys for failure to present evidence of brain damage during the sentencing phase. Mansnerus, suprá note 176.

211 See, e.g., Richard E. Redding, Why It Is Essential To Teach About Mental Health Issues in Criminal Law (And a Primer on How To Do It), 14 WASH. U. J.L. \& Pol'y 407, 418 (2004) ("[E]vidence of frontal lobe dysfunction is now being introduced in criminal cases vis-a-vis issues of criminal responsibility and mitigation."). Later, Redding notes that mental health evidence is "ubiquitous" in capital cases and takes it as settled that capital defendants have an especially high prevalence of mental (particularly neuropsychological) disorders. Id. at 436; see also Redding, supra note 208, at 53 (arguing that insanity defense should reflect modern neuroscience research showing that defendants with frontal lobe dysfunction have difficulty conforming their behavior to societal expectations); Seiden, supra note 176, at 396 (noting that "the strongest use for evidence of frontal lobe dysfunction is in the mitigation context" and predicting that more lawyers will present frontal lobe dysfunction defenses as scientific evidence of effects of frontal lobe dysfunction grows); Steven R. Kiersh, How To Use and Combat Experts in Federal Death Penalty Cases, 2 Ass'N Trial Law. Am. Ann. Convention Reference Materials 1793 (2000) (exhorting capital defense attorneys that "[y]our mental impairment experts must be well qualified and familiar with prevailing theory on such issues as frontal lobe brain dysfunction" because it "can usually be found and used as mitigation evidence").

212 E.g., Hoskins v. State, 735 So. 2d 202, 203, 209-10 (Fla. 1997) (remanding for limited purpose of conducting PET scan); People v. Jones, 620 N.Y.S.2d 656, 657-58 (App. Div. 1994) (holding failure to permit neurological testing for defendant to show impaired "ability to think quickly and flexibly" and "ability to perceive risk" to be reversible error), aff'd, 654 N.E.2d 1209 (N.Y. 1995).

213 See Rogers v. State, 783 So. 2d 980, 998-99 (Fla. 2001) (detailing lower court's authorization of funding for MRI scan).

214 See supra notes $169-81$ and accompanying text. 
juries were presented with neuroimaging evidence and nevertheless imposed or recommended a sentence of death. ${ }^{215}$

\section{B. Long-Term Aim: The Overthrow of Retribution}

Our penal system is highly counterproductive from a consequentialist perspective ... and yet it remains in place because retributivist principles have a powerful moral and political appeal. It is possible, however, that neuroscience will change these moral intuitions by undermining the intuitive, libertarian conceptions of free will upon which retributivism depends.

At this time, the law deals firmly but mercifully with individuals whose behavior is obviously the product of forces beyond their control. Some day, the law may treat all convicted criminals this way. That is, humanely. ${ }^{216}$

- Joshua Greene and Jonathan Cohen

215 See, e.g., Jackson v. Calderon, No. CV 91-4249-R, 1997 WL 855516, at *1, *6 (C.D. Cal. Nov. 14, 1997) (EEG used to show results of chronic drug use, jury sentenced death); People v. Smith, 107 P.3d 229, 233-34 (Cal. 2005) (PET showing defendant's "brain damage" introduced by Monte Buchsbaum at sentencing, jury sentenced death); People v. Gutierrez, 52 P.3d 572, 585, 589 (Cal. 2002) ("brain scans" presented at trial to show lesions on defendant's frontal lobes, jury sentenced death); People v. Kraft, 5 P.3d 68, 81, 98 (Cal. 2000) (PET scan introduced at sentencing, jury sentenced death); People v. Holt, 937 P.2d 213, 226, 231 (Cal. 1997) (PET and EEG showing abnormalities in frontal and temporal lobes as well as damage to cingulate gyrus region of brain presented at penalty phase, jury sentenced death); Johnston v. State, 841 So. $2 \mathrm{~d} 349,353-55$ (Fla. 2002) (expert testimony based on MRI, EEG, and PET presented at sentencing showing that defendant's "frontal lobe area had substantially less activity than was normal (below the first percentile)," trial court followed jury recommendation of death sentence); Smithers v. State, 826 So. 2d 916, 921-22 (Fla. 2002) (expert testified at sentencing that "PET scan of [defendant's] head was abnormal and was consistent with brain damage due to head trauma," trial judge accepted jury recommendation of death sentence); Sexton v. State, 775 So. 2d 923, 929, 936 (Fla. 2000) (expert testimony based on MRI and PET scans presented to show defendant's "dysfunctional limbic system in the lower half of the brain" and "structural injury on the top half of his brain," trial judge accepted jury recommendation of death sentence); State v. Timmendequas, 737 A.2d 55, 65, 71 (N.J. 1999) (expert testimony based on SPECT results presented at penalty phase describing "possible serious problem with defendant's brain," court sentenced defendant to death following jury finding that aggravating factors outweighed mitigating factors); State v. Reid, No. M2003-00539-CCAR3-DD, 2005 WL 1315689, at *1, *15 (Tenn. Crim. App. Dec. 27, 2005) (MRI and PET used to show shrinkage to left temporal lobe, jury sentenced death); Ex parte Simpson, 136 S.W.3d 660, 661, 665 (Tex. Crim. App. 2004) (experts testified regarding MRI and EEG results, court sentenced death).

216 Greene \& Cohen, supra note 57, at 1783-84. 
But although it may seem dehumanizing to medicalize people into being broken cars, it can still be vastly more humane than moralizing them into being sinners. ${ }^{217}$

- Robert Sapolsky

The foregoing discussion identified and articulated what appears to be a clearly defined project on the part of cognitive neuroscientists to affect capital sentencing. That is, they hope to use neuroimaging research on the roots of criminal violence to aid capital defendants in mitigation claims. This aspiration is for the short term: it is aimed at immediate, concrete, and practical interventions in the existing framework of capital sentencing. But the cognitive neuroscientists who are active in this area also have a longer-term, more theoretical aspiration for criminal justice. They aim to work a radical conceptual revision of criminal punishment itself; more specifically, they seek to use the premises and tools of neuroscience-and neuroimaging in particular - to embarrass, undermine, and ultimately overthrow retributive justice as a principle of punishment. Once retribution is discredited, they contend, criminal law will be animated solely by its proper end: namely, the purely forward-looking, consequentialist goal of avoiding socially harmful behavior. This new approach, it is hoped, will usher in a regime of "therapeutic justice," 218 wherein criminal defendants will be treated more humanely.

The most comprehensive articulation and defense of this longterm aspiration for criminal punishment reform was advanced in two papers published in 2004-one by coauthors Joshua Greene and Jonathan Cohen ${ }^{219}$ and the other by Robert Sapolsky. ${ }^{220}$

Greene and Cohen argue that advances in cognitive neuroscience-enabled by neuroimaging-will ultimately demonstrate that "ordinary conceptions of human action and responsibility" are false. "[A]s a result, the legal principles we have devised to reflect these conceptions may be flawed" and must be radically overhauled and replaced with principles that are grounded in a neuroscientific view of the truth about free will and human agency. 221 The primary focus of

217 Sapolsky, supra note 15 , at 1794.

218 See Bufkin \& Luttrell, supra note 20, at 186 (advocating "therapeutic justice" approach for its "holistic treatment regimens that hold offenders to 'scientifically rational and legally appropriate degree[s] of accountability" (alteration in original) (quoting Richard L. Nygaard, The Dawn of Therapeutic Justice, in The Science, Treatment, AND Prevention of Antisocial Behaviors 23-1, 23-12 (Diana H. Fishbein ed., 2000))).

219 Greene \& Cohen, supra note 57 . This paper and the others from the same symposium have since been published in a book entitled LAW AND THE BRAIN (Semir Zeki \& Oliver Goodenough eds., 2006).

220 Sapolsky, supra note 15.

221 Greene \& Cohen, supra note 57, at 1775. 
their critique is the principle of retributive justice-which, they assert, "depends on an intuitive, libertarian notion of free will that is undermined by science."222

In defense of this thesis, Greene and Cohen first reprise the familiar dichotomy of consequentialism ("which emerges from the classical utilitarian tradition") ${ }^{223}$ and retribution as both the general and distributive justifications for criminal punishment. They define consequentialism as a doctrine that regards punishment as "merely an instrument for promoting future social welfare" 224 and that seeks to prevent "future crime through the deterrent effect of the law and the containment of dangerous individuals." 225 By contrast, they define retribution as advocating the principle that "in the absence of mitigating circumstances, people who engage in criminal behaviour deserve to be punished." 226

Greene and Cohen then turn to the ancient (yet ongoing) debate over the nature and intelligibility of free will. They articulate a tripartite typology of positions on the issue: hard determinism, libertarianism, and compatibilism. ${ }^{227}$ Hard determinism, as the name implies, rejects the concept of free will. It holds that free will is fundamentally incompatible with the premise that all human action can be sufficiently explained by material causes that are necessarily bound by the laws of physics and previous events ("past states of the world"). ${ }^{228}$ Libertarianism (as characterized by Greene and Cohen) accepts the claim that free will and determinism are incompatible but nevertheless concludes that the world is not, in fact, completely determined by the laws governing the motion and rest of matter. ${ }^{229}$ In contrast, compatibilism holds that material determinism and free will are reconcilable, ${ }^{230}$ though compatibilism's conception of free will is more metaphysically modest than that of libertarianism.

Greene and Cohen argue that insofar as advances in neuroscience have begun to reveal the purely material causes of human thought and choice, they have also begun to undermine the fundamental tenets of libertarianism and thus retributive punishment. Libertarianism sup-

222 Id. at 1776.

223 Id.

224 Id. at 1775.

$225 \mathrm{Id}$. at 1776.

226 Id.

227 Id. at 1777.

228 Id. Greene and Cohen credit this particular formulation of determinism to Peter van Inwagen. Id. at 1777, 1785 (citing Peter van Inwagen, The Incompatibility of Free Will and Determinism, in FreE WILL 46 (Gary Watson ed., 1982).

229 Id. at 1777.

230 Id. 
plies the strong conception of free will (and thus moral responsibility) on which the doctrine of retribution relies. Greene and Cohen argue, however, that the strength of the concept of free will posited by libertarianism arises from its claim to operate through a nonmaterial mechanism-a proposition increasingly at odds with modern science. ${ }^{231}$ They contend that ultimately neuroimaging will entirely undermine the antimaterialist foundations of the libertarian position on free will, thus removing the grounding necessary for just deserts. ${ }^{232}$ Moreover, it is evident that retributive justice is conceptually irreconcilable with hard determinism: if all actions are sufficiently determined by material causes beyond anyone's control, the notions of culpability and just deserts upon on which retribution depends are unintelligible.

Greene and Cohen additionally assert that compatibilism's modest account of free will is not sufficiently robust to support the exacting demands of retribution, either as a general aim or as a distributive principle. ${ }^{233}$ They describe a compatibilist vision of free will, one that defines free will as the minimal capacity for rational actionnamely, the ability to produce "behaviour that serves [one's] desires in light of [his] beliefs." 234 As they describe, Stephen Morse has eloquently and forcefully argued that the law is constructed with this minimalist conception of free will in mind. ${ }^{235}$ Law, Morse maintains, is compatibilist and thus is not threatened by any proof of determinism that neuroimaging may eventually offer. ${ }^{236}$ In support of his claim, Morse points to the criminal law, which refuses to excuse from guilt those defendants who are laboring under a defect of mind, so long as they satisfy a minimal cognitive and volitional threshold. ${ }^{237}$ Greene and Cohen respond that while the law may formally focus on the question of minimal rationality, what people in society really care about is whether the defendant is responsible in a richer sense-one rooted in libertarian conceptions of free will. ${ }^{238}$ That is, even if the defendant is shown to be minimally rational in a legal sense, citizens will still ask whether it was "really him" who committed the crime, or whether it was "his upbringing," "his genes," "his circumstances," or "his brain" that were truly responsible.239 These questions, Greene

231 Id.

232 Id.

233 Id. at 1783.

234 Id. at 1778.

235 Id.; see also Morse, supra note 69, at 170.

236 Greene \& Cohen, supra note 57, at 1778; Morse, supra note 69 , at 162-81.

237 Morse, supra note 69, at 180-81; accord Greene \& Cohen, supra note 57, at 1778.

238 Greene \& Cohen, supra note 57 , at $1778-80$.

239 Id. at $1778-79$. 
and Cohen argue, arise from a libertarian vision of free will that does not accept the materialist determinism of Morse's compatabilism but rather is animated by a dualist premise that the brain and the mind are distinct (though interacting) entities. ${ }^{240}$ Thus, while the law as written may be (as Morse contends) formally compatabilist, it is actually driven by the "libertarian moral intuitions" of the citizens who implement it. ${ }^{241}$

Greene and Cohen characterize this tension between the law's formal requirements and society's richer conception of free will as an unstable "marriage of convenience." 242 They predict that neuroimaging will force a crisis in this union: cognitive neuroscience (aided by neuroimaging) will ultimately show that there is no difference between "him" and "his brain," 243 thus proving that the foundations of the libertarian dualist intuitions about human agency are untenable. This forms the basis for their belief that Morse underestimates the transformative power of neuroimaging on the law and especially on criminal punishment.

It is far beyond the scope of this Article to try to resolve this rich and vexed dispute about the future impact of neuroimaging on the law as a whole. Nevertheless, it is necessary to briefly reflect on how this debate plays out in the context of capital sentencing. Morse is certainly correct that the legal standard for diminished capacity for the purpose of determining legal guilt is modest; defendants rightly can be characterized as needing only "minimal rationality" in order to be held fully accountable for their actions. This is borne out by the small percentage of cases in which defendants raise the defense of legal insanity and the even smaller portion of cases in which such a defense succeeds. $^{244}$ But in the context of capital sentencing, which is animated by a particularly rich and textured conception of moral responsibility, Greene and Cohen's analysis is especially accurate. The Supreme Court has construed the Constitution to require the consideration of all mitigating factors relevant to a criminal defendant's culpability in meting out capital punishment. ${ }^{245}$ The very doctrine of mitigation is driven by questions like those that Greene and Cohen

240 Id. at 1779.

241 Id. at 1778.

242 Id.

243 Id. at $1780-81$.

244 See An Overview of the Impact of Neuroscience Evidence in Criminal Law, supra note 125 ("That said, the insanity defense is rarely invoked, and is even more rarely successful.").

245 See, e.g., Lockett v. Ohio, 438 U.S. 586, 608 (1978) ("To meet constitutional requirements, a death penalty statute must not preclude consideration of relevant mitigating factors."). 
argue society "really" cares about, such as "[w]as it him," or was it "his brain," "his upbringing," or his "circumstances?"246 Morse is right that these questions do not currently bear on legal guilt, but they do bear significantly on the kind of punishment imposed on the legally guilty. So it would seem that capital sentencing is largely driven by a metaphysically ambitious conception of human agency-one that is at odds with the conception that animates our determinations of guilt and innocence.

According to Greene and Cohen, only libertarian incompatibilism can provide adequate support to the principle of retributive justice. But they predict (and indeed, hope) that cognitive neuroscience will shatter this foundation. They note that while philosophical arguments against free will have not proven persuasive to the general population, science supported by neuroimaging will succeed where philosophy has failed:

Arguments are nice, but physical demonstrations are far more compelling. What neuroscience does, and will continue to do at an accelerated pace, is elucidate the 'when', 'where' and 'how' of the mechanical processes that cause behavior. It is one thing to deny that human decision-making is purely mechanical when your opponent offers only a general, philosophical argument. It is quite another to hold your ground when your opponent can make detailed predictions about how these mechanical processes work, complete with images of the brain structures involved and equations that describe their function. ${ }^{247}$

Greene and Cohen argue that when and if the notion of human agency is shown to be illusory, societal attitudes may well change. ${ }^{248}$ Eventually the law of punishment will have to follow suit and reflect the newly revealed truths about free will. In other words, once society internalizes the lessons of cognitive neuroscience as they bear on moral (and thus criminal) responsibility, retribution-relying as it does on a false understanding of human agency — will be eliminated as a legitimate general or distributive justification for punishment. ${ }^{249}$

Greene and Cohen consider the end of retributive justice salutary and desirable. They assert that retributivism is largely responsible for the "counter-productive" state of the American penal system ${ }^{250}$ and advance consequentialism as the sole legitimate justification for pun-

246 Greene \& Cohen, supra note 57, at 1778-79.

247 Id. at 1781.

248 Id. at 1783.

249 Id.

250 Id. 
ishment. 251 Without free will-and hence, without retribution-punishment can be fashioned solely with the future benefits to society in mind. Criminal offenders can still be held "responsible" for their actions, but without the moral stigma and judgment that retributive justice implies. ${ }^{252}$ Sentencing can promote beneficial effects for society by deterring future harms and incapacitating only those who would visit such harms upon the polity. ${ }^{253}$ Greene and Cohen's aspirational framework preserves excuse defenses (such as insanity and duress) for those cases where it can be shown that the deterrence of such offenders would not be effective. ${ }^{254}$ But retribution would be laid to rest forever as a pernicious fiction. ${ }^{255}$

Greene and Cohen conclude by summarizing their aspirations for criminal punishment in the following way:

Free will as we ordinarily understand it is an illusion generated by our cognitive architecture.... At this time, the law deals firmly but mercifully with individuals whose behaviour is obviously the product of forces that are ultimately beyond their control. Some day, the law may treat all convicted criminals this way. That is, humanely. ${ }^{256}$

Greene and Cohen are not alone in their criticisms of retributive justice. Robert Sapolsky notes that "at a logical extreme, a neurobiological framework may indeed eliminate blame," but adds that the institution of criminal punishment is still necessary for the purpose of

251 Id.

252 Id.

253 See id. ("[C]onsequentialists . . . can hold people responsible for crimes simply because doing so has, on balance, beneficial effects through deterrence, containment, etc.").

254 Id.

255 Id. Greene and Cohen do not believe merely that the overthrow of retribution by cognitive neuroscience will yield a better functioning system of criminal justice; they believe that it will make society more humane for criminal defendants. Id. at 1784 . Eliminating the moral stigma of retributive justice and embracing the hard determinist account of human agency will lead society to realize that the criminal does not deserve punishment and thus is not rightly the object of hatred and resentment. Greene and Cohen acknowledge the difficulty that people might have in letting go of their deeply rooted beliefs in free will. See id. at 1781-83 (suggesting that non-existence of free will contradicts millenia-old patterns of human thinking). Indeed, they are not sanguine about the possibility that this will be feasible in all areas of life. See id. at 1781 (observing that narcissistic beliefs, such as uniqueness of humans, repeatedly have succumbed to new, more accurate scientific understandings). In response to this worry, they argue that for the most important matters (such as capital sentencing), we should act bravely in accord with those truths that we know about human agency, discarding principles of retributive justice and taking our bearings solely from consequentialist considerations about society's future well-being. See id. at 1784 (discussing need to reject free will within criminal system).

256 Id. at 1784. 
protecting society from future harms. 257 Sapolsky echoes (in a fashion) Greene and Cohen: "To understand is not to forgive or to do nothing; whereas you do not ponder whether to forgive a car that, because of problems with its brakes, has injured someone, you nevertheless protect society from it."258 Sapolsky shares Greene and Cohen's desire to shed a framework that implicitly regards criminal defendants as morally blameworthy, preferring a consequentialist system even though it adopts an arguably diminished understanding of human personhood. 259

Practitioners of neuroimaging whose work contributes directly or indirectly to the short-term project of aiding capital defendants with mitigation claims have also embraced these long-term aspirations. ${ }^{260}$ For example, some have argued that retributive justice (grounded in "the assumption that human will or choice ultimately governs behavior") 261 accounts for factors "with no inherent explanatory worth" that "are summoned to justify less-than-stellar communitylevel interventions and unproductive institutionalization."262 Such practitioners believe that the new findings of cognitive neuroscience should steer society away from retribution and towards a regime of "therapeutic justice" in which offenders will be held to "scientifically rational and legally appropriate degree[s] of accountability."263 They also believe that neuroimaging research will ultimately lead to the refinement and improvement of the instruments used for the classification and prediction of violent criminal behavior. ${ }^{264}$

257 Sapolsky, supra note 15 , at 1794 .

258 Id.

259 See id. ("But although it may seem dehumanizing to medicalize people into being broken cars, it can still be vastly more humane than moralizing them into being sinners.").

260 Vickie Luttrell (a psychologist with neuroscience training) and Jana Bufkin (a criminologist) reached conclusions similar to those of Cohen, Greene, and Sapolsky following their 2005 review of seventeen neuroimaging studies of criminal violence. Bufkin \& Luttrell, supra note 20, at 187-88. Bufkin and Luttrell argue that these studies shed important light on the neuroanatomical origins of criminal violence. Id. at 185-86. They agree with the Greene-Cohen-Sapolsky thesis that the criminal justice system should take its bearings from these findings rather than from "legal variables" relating to just deserts. Id. at 186.

261 Id. at 186.

262 Id.

263 Id. (alteration in original) (internal quotation marks and citation omitted).

$264 \mathrm{Id}$. at 187. Other neuroscientists, many of whom have testified on behalf of capital defendants at sentencing, have evinced sympathy and agreement with the Greene-CohenSapolsky thesis. Buchsbaum-arguably the founding father of neuroimaging in capital mitigation-echoed this theme in his presentation at a recent conference, quoting Bertrand Russell:

A man infected with cholera is not allowed to mix freely with the population, but we do not think him wicked. We may similarly be obliged to interfere with 
In short, it is clear that, alongside their narrow, short-term goal of intervening as experts for capital defendants for purposes of mitigation at sentencing, cognitive neuroscientists in this field have a far more ambitious goal for the institution of capital punishment: to use the claims of their discipline and the new powers conferred by neuroimaging to overthrow retributive justice as a legitimate justification for criminal sanctions.

This long-term goal is very much in the spirit of late-eighteenthcentury thinkers such as Jeremy Bentham and Cesare, Marquis of Beccaria, who regarded punishment of the guilty as justified only insofar as it was instrumental to the protection of society and promoting human happiness. ${ }^{265}$ As George Fletcher observed, under their utilitarian approach, "No form of punishment could be justified unless it was the cheapest available means for serving these social ends." 266

The long-term aim also mirrors, in many respects, the work of Barbara Wootton, Baroness of Abinger. Lady Wootton, a twentiethcentury criminologist, rejected the notion of criminal "punishment" altogether, arguing instead that the only intelligible goal for the criminal law is to be a "system of purely forward-looking social hygiene in

the freedom of a murderer, but we should not have a feeling of moral reprobation in the one case more than in the other.

Buchsbaum, supra note 178, at 56. Similarly, Raine has said that his neuroimaging research on criminal violence has led him to conclude that the evolutionary mechanism of retribution is no longer useful and that abandonment of this principle of punishment will lead to the understanding and forgiveness of certain violent offenders. Raine, supra note 176 , at 28 . He argues that retribution is merely a quasi-religious sensibility that satisfies our urge to "blame someone." Id at 28-29. He predicts (and hopes) that cognitive neuroscience will enlighten society such that it will eventually view the execution of prisoners as it now views the burning of witches. Id. at 29.

Psychiatrist and mitigation expert Daniel Amen seems to agree that the moral framework on which retribution is erected is called into question by advances in neuroimaging, explaining that "I used to have this set idea that there was right and wrong, heaven and hell and purgatory. The whole thing was pretty clear to me until I started looking at these brain scans. Then I thought to myself, 'Uh-oh, maybe there's more to it.'" Lasden, supra note 136, at 29 (quoting Amen). Rita Carter adds that "[i]f acts of 'mindless' violence really are that - no more conscious than the kick of a leg when the knee is tapped-it seems pointless, as well as unfair, to punish the perpetrators." RITA CARTER, MAPPING THE Mind 92 (1998). Patricia Churchland likewise argues that neuroscience renders retributive justice unintelligible, and that the right aim of punishment is to prevent social harms: "My hypothesis is that holding people responsible and punishing the guilty is rooted not in some abstract relationship between a Platonic conception of justice and contra-causal willing, but in the fundamental social need for civil behavior." Churchland, supra note 35, at 10 (emphasis added).

265 See George P. Fletcher, The Metamorphosis of Larceny, 89 HARV. L. REv. 469, 502-03 (1976) (describing criminological goals of Bentham and Beccaria).

266 Id. at 502 . Their arguments provided the conceptual background to what Fletcher calls "protectionist criminology." Id. at 503. 
which our only concern when we have an offender to deal with is with the future and the rational aim of prevention of further crime."267 This view led Wootton to argue for a complete abandonment of mens rea as an element of guilt in favor of a system of strict criminal liability. ${ }^{268}$ She believed that a person's intentions at the time of a crime are not knowable and, indeed, not relevant to the question of guilt. A defendant's mental state, to Wootton, would only be relevant as a predictive instrument to be used in preventing the same defendant from offending in the future. ${ }^{269}$ Under her approach, the state would take custody of an offender upon his conviction for a criminal act and give him medical treatment or incarcerate him. ${ }^{270}$ Wootton's approach blurs the distinction between prisons and hospitals: Both are "places of safety" where "offenders will receive the treatment which experience suggest [sic] is most likely to evoke the desired response" of preventing future crime. ${ }^{271}$ Wootton's framework thus explicitly and intentionally conflates punishment with therapy. ${ }^{272}$

It is worth noting that while Greene and Cohen fundamentally share with Wootton the same view of the aims of criminal law, they have opposite views on whether the reasons for antisocial choices can be known. Wootton regards such reasons as unknowable, whereas Greene and Cohen are confident that someday they will become discernible through neuroimaging. ${ }^{273}$

In sum, the cognitive neuroscience aspiration for capital sentencing consists of two dimensions: a short-term aim to aid capital

267 H.L.A. Hart, Book Review, 74 Yale L.J. 1325, 1328 (1965) (reviewing Barbara Wootton, Crime and the Criminal Law (1963)).

268 Id. at $1327-28$.

269 Id.

270 Id. at 1327.

271 Id. at 1327-28 (internal quotation marks omitted).

272 Wootton's aspirational system of criminal law seems to closely resemble Bufkin and Luttrell's vision of "therapeutic justice," Raine's description of crime as a disease, and Sapolsky's metaphor of the criminal defendant as a broken automobile. See Bufkin \& Luttrell, supra note 20, at 186-87 (describing model of therapeutic justice); Raine, supra note 176, at 29 (hoping that two hundred years from now we will view serious criminal behavior as clinical disorder); Sapolsky, supra note 15, at 1794 ("But although it may seem dehumanizing to medicalize people into being broken cars, it can still be vastly more humane than moralizing them into being sinners."). Wootton's conviction that the sole purpose of the criminal law is the prevention of socially harmful behavior is shared explicitly by Greene and Cohen. See Greene \& Cohen, supra note 57, at 1775 (arguing that, under adopted consequentialist view, punishment is "merely an instrument for promoting future social welfare").

273 Greene and Cohen predict that someday in the future, neuroscientists will be able to watch the decisionmaking process in real time using functional neuroimaging. See Greene \& Cohen, supra note 57, at 1781 (describing hypothetical future scenario in which neuroimaging facilitates direct, real-time observation of neural processes underlying human subject's choice between soup and salad). 
defendants in a practical way in their mitigation claims, and a longerterm, more radical aspiration to eliminate retributive justice as a distributive principle of punishment.

\section{III}

A Critique of the Aspirations of Cognitive Neuroscience: The Complexity of Punishment

Little Bill Daggett: I don't deserve this. To die like this. I was building a house.

William Munny: Deserve's got nothin' to do with it. [Aims at Daggett and fires. $]^{274}$

There are many ways that one might approach the assessment of the comprehensive aspirations of cognitive neuroscientists for capital sentencing. As noted at the outset, this Article seeks to provide a friendly critique; that is, the analysis proceeds from a position of sympathy and solidarity with the humanitarian impulses-and with the general antipathy for the death penalty-that animate the cognitive neuroscientists working in this field. Thus, the wisdom and soundness of the cognitive neuroscience project is being appraised according to the metric of its own humanitarian ambitions: namely, success in helping convicted capital defendants persuade jurors and judges not to impose a sentence of death, thereby creating a more compassionate and humane legal regime for such defendants. Unfortunately, it seems unlikely that these ends would be achieved if the short- and long-term aims of cognitive neuroscientists described in Part II were ever actually realized. To the contrary, it seems likely that the criminal regime desired by cognitive neuroscientists would, tragically and ironically, prove far harsher and less humane for capital defendants than the current system.

Why? Simply put, the project, taken as a whole, is utterly at war with itself. Its short-term aim relies on a particular theory of mitigation that is firmly grounded in retribution-a principle whose foundations are explicitly rejected by the architects of the cognitive neuroscience project. Conversely, the project's long-term aim is devoted to dismantling the doctrinal foundation (i.e., retribution) upon which the short-term aspiration depends. Thus, the success of its long-term goal would necessarily defeat the project's short-term goal. Worse still, the extant mechanisms that the long-term project would explicitly leave in place (that is, those features of the capital sentencing framework animated solely by the consequentialist goal of

274 UNFORGIVEN (Warner Bros. 1992). 
avoiding societal harms) constitute arguably the single gravest threat to a capital defendant's life. If the capital sentencing regime were remade according to the aspirations of the long-term plan, this threat would be dramatically amplified precisely because of the research of cognitive neuroscientists. Indeed, as I will argue below, it is only by virtue of the doctrine of just deserts that neuroimaging evidence of the roots of criminal violence can be understood as reducing a capital defendant's culpability. This conclusion accords with the (perhaps counterintuitive) fact that just deserts has served as arguably the most valuable limiting principle in the American jurisprudence of capital sentencing, and even perhaps the criminal law more broadly.

\section{A. The Short-Term Aspiration: Mitigation and Just Deserts}

As discussed extensively above, the formal context in which cognitive neuroscientists seek to implement their short-term aim is at the mitigation phase of capital sentencing. ${ }^{275}$ Mitigation involves the presentation of evidence regarding the character, background, or other pertinent features of an already convicted defendant that might convince the jury that the defendant's degree of culpability merits life imprisonment rather than death. ${ }^{276}$ However, defendants who reach the sentencing phase have, by necessity, already satisfied the prerequisite legal thresholds for sanity, competence, and the capacity to formulate the relevant mens rea. At this stage of the criminal process, therefore, "it is impossible to offer an 'excuse' for the defendant's acts. The jury already knows that no justifiable excuse exists for what the defendant did." 277 Mitigation evidence is presented in order to "inspire[ ] compassion . . . offer[ing] neither justification, nor excuse for the capital crime." 278 A mitigation claim is thus a plea for leniency in spite of a prior finding of legal guilt.

There are many ways in which capital defendants and the experts working on their behalf seek to move jurors towards leniency. ${ }^{279}$ One of the most frequent strategies is to introduce evidence that the defendant was laboring under a mental disturbance or incapacity that, while

275 See supra Part II.A.

276 John M. Fabian, Death Penalty Mitigation and the Role of the Forensic Psychologist, 27 Law \& Psychol. Rev. 73, 78 (2003).

277 Peter T. Hansen, Mitigation: An Outline of Law, Method and Strategy, CAP. Def. Dig., Apr. 1992, at 29, 32.

278 Fabian, supra note 276, at 78 (quoting Russell Stetler, Mental Disabilities and Mitigation, Champion, Apr. 1999, at 49, 50).

279 For an illuminating typology of mitigating evidence, see Jeffrey L. Kirchmeier, $A$ Tear in the Eye of the Law: Mitigating Factors and the Progression Toward a Disease Theory of Criminal Justice, 83 OR. L. Rev. 631, 656-87 (2004). For an illustrative statutory example of admissible mitigating evidence, see VA. CODE ANN. § 19.2-264.4(B) (2004). 
not an excuse for purposes of guilt, should nevertheless reduce his culpability. ${ }^{280}$ As discussed in Part II, this is the approach dictated by the short-term aspiration.

This strategy, however, is squarely rooted in a distributive theory of punishment that proponents of the cognitive neuroscience project explicitly repudiate as a principal source of the irrationality and brutality that plague the current system. Paul Robinson has called this theory "punishment according to desert," as it is an approach that distributes punishment "according to the offender's personal blameworthiness for the past offense, which takes account not only of the seriousness of the offense, but also the full range of culpability, capacity, and situational factors that we understand to affect an offender's blameworthiness." 281 The Supreme Court's death penalty jurisprudence confirms that the concept of mitigation grows directly out of the requirements of retributive justice:

Underlying [the Supreme Court precedents bearing on the doctrine of mitigation] is the principle that punishment should be directly related to the personal culpability of the criminal defendant. If the sentencer is to make an individualized assessment of the appropriateness of the death penalty, "evidence about the defendant's background and character is relevant because of the belief, long held by this society, that defendants who commit criminal acts that are attributable to a disadvantaged background, or to emotional and mental problems, may be less culpable than defendants who have no such excuse." 282

Additionally, the AMA's amicus brief in Roper powerfully illustrates that the short-term aspiration is driven entirely by an appeal to the

280 See Gladwell, supra note 208, at 146 (discussing role neurology and psychiatry should play in debate over competency and responsibility).

281 Paul H. Robinson, The A.L.I.'s Proposed Distributive Principle of "Limiting Retributivism": Does It Mean in Practice Anything Other than Pure Desert?, 7 Buff. CRIM. L. Rev. 3, 5 (2003) [hereinafter Robinson, Limiting Retributivism]. In a recent paper, Robinson offered a comprehensive typology of "desert." Paul H. Robinson, Competing Conceptions of Modern Desert: Vengeful, Deontological, and Empirical 5, 7-8 (Univ. of Pa. Law Sch. Pub. Law \& Legal Theory Research Paper Series, Research Paper No. 06-32, 2006), available at http://papers.ssrn.com/abstract $=924917$ (distinguishing "Vengeful Desert," which exacts same measure of suffering from defendant as that which he caused victim, from "Deontological Desert," which judges blameworthiness according to abstract notions of good and evil, and "Empirical Desert," which focuses on blameworthiness as defined by shared intuitions of justice in relevant community).

282 Penry v. Lynaugh, 492 U.S. 302, 319 (1989) (quoting California v. Brown, 479 U.S. 538, 545 (1987) (O'Connor, J., concurring)), overruled in part by Atkins v. Virginia, 536 U.S. 304 (2002). 
culpability-mitigating effects of the defendant's neurological condition. ${ }^{283}$

It is clear that Justice Kennedy's opinion in Roper was likewise principally animated by concerns about just deserts: "Retribution is not proportional if the law's most severe penalty is imposed on one whose culpability or blameworthiness is diminished, to a substantial degree, by reason of youth and immaturity."284 Kennedy also observed that, given their diminished capacity for self-control and risk assessment, it was "unclear" whether the death penalty would have a sufficient deterrent effect on potential juvenile offenders. ${ }^{285}$ In this way, Justice Kennedy's doubts about deterrence (the second principle justifying the death penalty as punishment) further bolstered his more emphatic arguments that retributive justice categorically requires sparing adolescents from the ultimate punishment. ${ }^{286}$

Justice Kennedy's majority opinion likewise echoed the arguments made in the AMA and APA briefs about the inadequacy of individualized capital sentencing as a safeguard against error and abuse in the capital context. Indeed, Kennedy went further, holding that juries would be incapable of treating youth as a mitigating factor on a case-by-case basis:

An unacceptable likelihood exists that the brutality or cold-blooded nature of any particular crime would overpower mitigating arguments based on youth as a matter of course. . . In some cases a defendant's youth may even be counted against him. In this very case ... the prosecutor argued Simmons' youth was aggravating rather than mitigating. 287

Cognitive neuroscientists who invoke neuroimaging evidence for purposes of capital mitigation embrace the strategy outlined in the AMA brief and adopted in Justice Kennedy's opinion. The shortterm aspiration is advanced by the claim that the defendant "is a

283 One of the authors of that brief, Aliya Haider, recently acknowledged that its principal strategy was to seek refuge within the doctrine of retribution:

The science brief argued that retribution would not be served by executing adolescents. In death penalty jurisprudence, culpability is the measure of retribution. The Court is committed to meting out punishments that are proportionate to the offender's culpability. Thus, in our science brief, we argued that juveniles' brains are anatomically different and deficient as compared to those of adults.

Haider, supra note 202, at 371 (footnotes omitted).

284 Roper v. Simmons, 543 U.S. 551, 571 (2005).

285 Id. at $571-72$.

286 Justice Kennedy did not mention the specific deterrent effect of the death penalty in this context. It is, of course, beyond dispute that executing a capital defendant permanently deters future crimes by that individual.

287 Roper, 543 U.S. at 573. 
human being with redeeming value, and that he or she suffered ... neurological ... damage ... that make[s] him or her less than 100 percent morally culpable for his or her behavior."288 But this approach trades on the very dichotomy of "him" versus "his brain" that just deserts invites-one that proponents of the long-term aspiration deplore as unintelligible. ${ }^{289}$ Thus, the short-term aspiration depends on precisely the principle of punishment that the long-term approach rules out of bounds.

\section{B. The Long-Term Aspiration: Prediction and Prevention}

Conversely, the long-term aspiration seeks to undermine and destroy the very distributive principle of retributive justice upon which the short-term counterpart depends. As discussed in Part II, proponents of the long-term goal regard just deserts as anathema to the only suitable goal of the criminal law-preventing future criminal harms. The long-term aspiration would thus preclude the introduction of mitigation evidence that bears on diminished culpability. It would leave in place only those mechanisms that promote the avoidance of crime. The mechanisms of capital sentencing best suited to this end are those that are calibrated to predict the social harms to be contained or avoided. As John Monahan has observed, "Assessing the likelihood of future crime ... is a central task of sentencing under the forward-looking principle of crime control." 290 By contrast, such considerations are "jurisprudentially irrelevant to sentencing under the backward-looking principle of punishment [according to] just deserts."291 Nothing in capital sentencing embodies the purely consequentialist spirit of the long-term cognitive neuroscience project as much as the aggravating factor of future dangerousness. To fully appreciate the impact that the long-term plan would like to have on capital sentencing, it is thus necessary to explore briefly the nature and contours of this element of death penalty jurisprudence.

"Future dangerousness" is a commonly invoked aggravating factor in capital sentencing. ${ }^{292}$ Prosecutors seeking the death penalty

288 Michael N. Burt, Forensics as Mitigation, http://www.goextranet.net/Seminars/ Dallas/BurtForensics.htm (last visited July 28, 2007).

289 See supra Part II.B.

290 Monahan, supra note 157 , at 396.

291 Id.

292 Twenty-one of the thirty-eight states with the death penalty include future dangerousness as an aggravating factor. Mitzi Dorland \& Daniel Krauss, The Danger of Dangerousness in Capital Sentencing: Exacerbating the Problem of Arbitrary and Capricious Decision-Making, 29 LAW \& Psychol. Rev. 63, 64 (2005). While only six states place primary emphasis on this factor by statute, these states account for a majority of the executions in the United States since the Supreme Court ended the Furman-era moratorium on 
bear the burden of persuading jurors beyond a reasonable doubt that at least one aggravating factor exists to make the defendant deatheligible. ${ }^{293}$ As one capital defense expert puts it, this is the stage of the trial where the government "suggest[s] to the jury that the defendant is a living hazard to civilization and a menacing threat to society." 294 To this end, prosecutors often submit the testimony of experts or laypersons regarding a defendant's future dangerousness or simply argue it themselves based on a variety of evidence. ${ }^{295}$ In those jurisdictions that prohibit the state from submitting an expert prediction of violence, prosecutors often try to establish future dangerousness through cross-examination of the defense's mitigation experts. ${ }^{296}$ Sometimes, as in Roper, ${ }^{297}$ prosecutors will try to turn the defendant's own mitigation claims against him, arguing that evidence of a violent disposition borne of abuse or a personality disorder is, in fact, demonstrative of future dangerousness. ${ }^{298}$ The Supreme Court affirmed the

the death penalty, Furman v. Georgia, 408 U.S. 238, 239-40 (1972) (per curiam), with its decisions in Gregg v. Georgia, 428 U.S. 153, 169 (1976), and Jurek v. Texas, 428 U.S. 262, 277 (1976). Dorland \& Krauss, supra, at 64, 66. For an illustrative sample of state statutory language, see Jeffrey L. Kirchmeier, Aggravating and Mitigating Factors: The Paradox of Today's Arbitrary and Mandatory Capital Punishment Scheme, 6 WM. \& MARY BILL RTs. J. 345, 415 n.373 (1998).

293 Ring v. Arizona, 536 U.S. 584, 609 (2002) (holding that in capital sentencing schemes where jury sits as trier of fact, facts underlying any statutory aggravating factors must be determined beyond reasonable doubt by jury rather than by judge). It is important to bear in mind that most, if not all, jurisdictions designate additional aggravating factors beyond "future dangerousness." See Simon \& Spaulding, supra note 170, at app. 4A at 102-07 (listing aggravating factors by jurisdiction).

294 Hansen, supra note 277, at 32.

295 See Erica Beecher-Monas \& Edgar Garcia-Rill, Danger at the Edge of Chaos: Predicting Violent Behavior in a Post-Daubert World, 24 CARdozo L. Rev. 1845, 1849 (2003) (listing ways that future dangerousness may be introduced); Dorland \& Krauss, supra note 292, at 64-65 (same). For a discussion of the Fifth and Sixth Amendment issues associated with state expert examinations of capital defendants for purposes of future dangerousness, see generally Welsh S. White, Government Psychiatric Examinations and the Death Penalty, 37 ARIZ. L. REV. 869 (1995).

296 See Beecher-Monas \& Garcia-Rill, supra note 295, at 1849-50 (noting problem of "opening the door" to arguments about future dangerousness).

297 See Roper v. Simmons, 543 U.S. 551, 558 (2005) (noting prosecutor's attempt to use potential mitigating factor of young age against defendant).

298 See, e.g., John H. Blume \& Sheri Lynn Johnson, The Fourth Circuit's “Double-Edged Sword": Eviscerating the Right to Present Mitigating Evidence and Beheading the Right to the Assistance of Counsel, 58 MD. L. REv. 1480, 1502 (1999) (discussing potential for prejudice when "evidence that seems intuitively mitigating may be, in the minds of some jurors, actually aggravating”); Robert F. Schopp, Two-Edged Swords, Dangerousness, and Expert Testimony in Capital Sentencing, 30 LAW \& PsYCHOL. Rev. 57,58 n.7 (2006) (noting that prosecutor in Roper characterized defendant's young age as "scary"). For an excellent overview of the issues in this area, see Beecher-Monas \& Garcia-Rill, supra note 295, at 1849-50, 1857. For cites to several critical commentaries, see Dorland \& Krauss, supra note 292 , at 66-67 nn.16-18. For additional discussion of these issues, see also Monahan, 
constitutionality of future dangerousness as an aggravating factor in capital sentencing thirty years ago in Jurek $v$. Texas. ${ }^{299}$ Seven years later, in Barefoot v. Estelle, the Court held that the state's use of the expert testimony of two psychiatrists to prove future dangerousness was constitutional, even though the experts' opinions were based on hypothetical questions rather than personal examinations of the defendant. ${ }^{300}$ Moreover, the Court reached its conclusion over the vigorous objections of the American Psychiatric Association, who argued in an amicus brief that such predictions were fatally unreliable. ${ }^{301}$

There are two principal scientific approaches to assessing future dangerousness. The first is clinical prediction, which relies on the judgment of experts (such as psychologists and psychiatrists) or laypersons (such as police or probation officers) to evaluate the defendant as an individual. The second is actuarial (or statistical) prediction, which evaluates defendants according to "explicit rules specifying which risk factors are to be measured, how those risk factors are to be scored, and how the scores are to be mathematically combined to yield an objective estimate of violence risk." 302 Among experts in the field, actuarial methods are thought to be significantly more reliable than clinical methods, ${ }^{303}$ though there are commentators who argue that all predictive efforts are insufficiently reliable to be permitted in capital sentencing. ${ }^{304}$

supra note 157 , at $427-28$, and Christopher Slobogin, $A$ Jurisprudence of Dangerousness, 98 Nw. U. L. Rev. 1, 48-58 (2003).

299428 U.S. $262,274-76$ (1976).

300463 U.S. 880,896 (1983).

301 See id. at 899 (stating that adversarial system is "competent to uncover, recognize, and take due account" of shortcomings of such evidence); see also Brief Amicus Curiae for the American Psychiatric Ass'n, Barefoot v. Estelle, 463 U.S. 880 (1983) (No. 82-6080).

302 Monahan, supra note 157, at 405-06; see also id. at 409-13 (describing three most prominent actuarial instruments for risk assessment: Violence Risk Appraisal Guide (VRAG); Historical, Clinical or Risk-Management Variables (HCR-20), and Classification of Violent Risk (COVR)); id. at 408 n.71 (referencing PCL-R).

303 Id. at 408.

304 E.g., Joanmarie Ilaria Davoli, Psychiatric Evidence on Trial, 56 SMU L. Rev. 2191, 2232 (2003) (arguing that psychiatric predictions of dangerousness should be excluded for "majority" of capital defendants who are not mentally ill because such predictions do not meet tests of relevance and reliability); Dorland \& Krauss, supra note 292, at 66 (citing "strong evidence" that "dangerousness predictions are inaccurate, unreliable, and inordinately prejudicial" and therefore are arbitrary and capricious). But see Beecher-Monas \& Garcia-Rill, supra note 295, at 1897-1900 (arguing that actuarial instruments provide "best information available" and should be given to jurors in capital sentencing proceedings); Monahan, supra note 157, at 427-34 (arguing that under certain prescribed circumstances, actuarial risk assessment is appropriate tool in both criminal and civil-commitment settings). 
Because the rules of evidence that govern criminal trials often do not apply to capital sentencing hearings, ${ }^{305}$ courts have wide latitude in deciding whether to admit evidence of future dangerousness at such proceedings. Thus, actuarial and clinical evidence of future dangerousness has been admitted in jurisdictions following both the Daubert and Frye standards, ${ }^{306}$ and clinicians have been permitted to testify even where they have not examined the defendant. David Faigman, an expert on the use and admissibility of scientific evidence in court, has observed that " $[\mathrm{m}]$ ost courts either entirely ignore evidentiary standards for expert testimony concerning future violence, or give it scant attention." 307 A brief survey of the types of evidence admitted to show future dangerousness at capital sentencing demonstrates the relatively unconstrained power of the courts in this context. ${ }^{308}$

305 E.g., United States v. Lee, 274 F.3d 485, 494 (8th Cir. 2001); see also David L. Faigiman et al., Science in the Law: Social and Behavioral Science Issues 79 \& n.10 (2002) (discussing implications of suspended or modified evidentiary standards on predictions of future violence).

306 See, e.g., United States v. Barnette, 211 F.3d 803, 815 (4th Cir. 2000) (admitting actuarial evidence of future dangerousness under Daubert); United States v. Rodriguez, $389 \mathrm{~F}$. Supp. 2d 1135, 1143-44 (D.N.D. 2005) (holding that psychiatric testimony regarding future dangerousness is admissible under Daubert); State v. Endreson, 498 P.2d 454, 458 (Ariz. 1972) (in banc) (noting that sentencing court heard clinical evidence of future dangerousness); Fair v. State, 161 P.3d 466, 468-69 (Wash. Ct. App. 2007) (noting that trial court found actuarial evidence of defendant's "high degree of psychopathy" to be "persuasive and credible"). Given that Daubert was decided ten years after Barefoot v. Estelle, 463 U.S. 880 (1983) (discussed supra notes 300-01 and accompanying text), some have wondered if the Daubert decision (setting the standard of admissibility of expert testimony under the federal rules) would actually require the exclusion of the evidence submitted in Barefoot. While at least one federal judge thinks so, others disagree. Compare Flores v. Johnson, 210 F.3d 456, 464 (5th Cir. 2000) (Garza, J., concurring) (noting that expert testimony of psychiatrist regarding future dangerousness "appears [to] fail[] all five Daubert factors"), with Barnette, 211 F.3d at 815 (admitting actuarial evidence of future dangerousness), and Rodriguez, 389 F. Supp. 2d at 1143-44 (holding that psychiatric testimony regarding future dangerousness is admissible). Moreover, virtually all of the commentary that has addressed this question concludes that Daubert does not, in principle, preclude the admission of "professional assessments of dangerousness in federal courts or in states that follow the Daubert decision." John Monahan, Violence Risk Assessment: Scientific Validity and Evidentiary Admissibility, 57 WASH. \& LEE L. Rev. 901, 916-18 (2000) (quoting Thomas R. Litwack \& Louis B. Schlesinger, Dangerousness Risk Assessments: Research, Legal, and Clinical Considerations, in THE HANDBOoK of Forensic PsyCHOLOGy 171, 192-93 (Allen K. Hess \& Irving B. Weinder eds., 2d ed. 1999)).

307 FAIGMAN ET AL., supra note 305, at 79-80 (including detailed discussion of why courts give little weight to evidentiary standards); see also, e.g., Lee, 274 F.3d at 494 ("Since the need to regulate the scope of testimony is less at the penalty phase than at the guilt phase of trial, parties may present evidence 'as to any matter relevant to the sentence." " (quoting 18 U.S.C. \$ 3593(c) (2000)); Beecher-Monas \& Garcia-Rill, supra note 295 , at 1856-60 (noting "anomalous" result that evidentiary standards are stricter in civil than criminal cases).

308 See, e.g., People v. Mertz, 842 N.E.2d 618, 653 (Ill. 2005) (admitting evidence that defendant had two tattoos of Grim Reaper and another of cross surrounded by skulls, and 
Prosecutors regularly invoke diagnoses of psychopathy or antisocial personality disorder in capital sentencing, ${ }^{309}$ likely because both are highly correlated with recidivist violence. ${ }^{310}$ Courts have specifically permitted both diagnoses to be introduced as evidence of future dangerousness at the sentencing phase of capital trials. ${ }^{311}$ This has

that his email address was "Cereal Kilr 2000"); Bell v. State, 938 S.W.2d 35, 49 (Tex. Crim. App. 1996) (en banc) (noting testimony of prison guard "that he had seen other death row inmates suddenly snap and become unexpectedly violent after a long periods [sic] of good behavior"); Lane v. State, 933 S.W.2d 504, 507 (Tex. Crim. App. 1996) (en banc) (allowing testimony of law enforcement officers, "derived from their observations of [the] defendant, about that defendant's character and the likelihood of future violence"); Simmons v. State, 594 S.W.2d 760, 763 (Tex. Crim. App. 1980) (en banc) (allowing testimony of former county attorney that defendant was dangerous); George v. Commonwealth, 411 S.E.2d 12, 17-18 (Va. 1991) (admitting evidence that defendant had been cruel to animals twenty years earlier).

309 See Fabian, supra note 276, at 93 ("[APD] is often present in capital cases, and is viewed as a pejorative factor .....); Jonathan H. Pincus, Neurologist's Role in Understanding Violence, 50 ARCHIVEs NeUROLOGY 867, 868 (1993) (noting with disapproval that every felon on death row has received APD diagnosis); see also Blume \& Voisin, supra note 160 , at 74 (referring to APD as "state's preferred diagnosis").

310 See Monahan, supra note 157 , at 421 \& n.116 (noting that construct of psychopathy is "now considered by some to have an 'unparalleled' ability to predict future violence in criminal samples" and observing that "[i]n [one s]tudy, a patient with a diagnosis of antisocial personality disorder was over three times more likely than a patient without such a diagnosis to commit a violent act within several months after discharge from the hospital"); see also Grant T. Harris et al., The Construct of Psychopathy, 28 CRIME \& JUST. 197, 198-99 (2001) ("Research on adult offenders has shown that psychopathic offenders are responsible for a disproportionate amount of crime." (citations omitted)). Some experts have argued that APD is a far less reliable proxy for future dangerousness than is psychopathy. See supra note 160.

311 See, e.g., Martinez v. Dretke, 99 F. App'x 538, 543-44 (5th Cir. 2004) (holding that admission of Hare Psychopathy Test did not violate defendant's due process rights); Lee, 274 F.3d at 495 (allowing government cross-examination that elicited evidence of psychopathy for purposes of determining future dangerousness); Barnette, 211 F.3d at 815-16 (finding PCL-R admissible under Daubert standard to show psychopathy and thus future dangerousness); Howard v. State, 153 S.W.3d 382, 384 (Tex. Crim. App. 2004) (en banc) (affirming use of APD diagnosis as aggravating factor going to future dangerousness); Will v. State, No. 74,306, 2004 WL 3093238, at*1-3 (Tex. Crim. App. Apr. 21, 2004) (finding testimony that defendant was "psychopathic deviate" relevant to future dangerousness); Walbey v. State, 926 S.W.2d 307, 311 (Tex. Crim. App. 1996) (finding testimony that defendant "exhibited many of the characteristics of a person diagnosed with anti-social personality disorder" relevant to future dangerousness); Alvarado v. State, 912 S.W.2d 199, 208-09 (Tex. Crim. App. 1995) (en banc) (affirming use of diagnosis of APD as aggravating factor going to future dangerousness); Richard v. State, 842 S.W.2d 279, 284 (Tex. Crim. App. 1992) (en banc) (same); Earhart v. State, 823 S.W.2d 607, 619-20 (Tex. Crim. App. 1991) (en banc) (finding testimony that defendant was "most likely . . . a sociopath or a psychopath" relevant to future dangerousness); Amos v. State, 819 S.W.2d 156, 162 (Tex. Crim. App. 1991) (en banc) (affirming use of psychiatrist's conclusion that defendant had APD as factor going to future dangerousness); see also Charles M. Sevilla, Anti-Social Personality Disorder: Justification for the Death Penalty?, 10 J. Contemp. Legal Issues 247, 252 n.19 (1999) (citing additional cases affirming prosecutors' use of APD diagnosis to show future dangerousness). 
proven to be a highly effective strategy for prosecutors given that the diagnostic criteria for each sound to the lay juror essentially like a straightforward description of "irreparable corruption"312 (to borrow Justice Kennedy's phrase from Roper). ${ }^{313}$ More importantly, courts do not regard either psychopathy or APD as an excusing condition for guilt or competence; neither is thought to sufficiently diminish the defendant's cognitive or volitional capacity for those purposes. ${ }^{314}$ Thus, either diagnosis both can have a devastating effect on the defendant's mitigation claims and can create an expectation in jurors' minds "that no rehabilitation is possible and that future criminal violence is inevitable."315

The diagnoses of APD and psychopathy have played a prominent role as aggravating factors in the capital context. ${ }^{316}$ Dr. James Grigson, an iconic and notorious figure in the jurisprudence of future dangerousness, serves as an extreme but illustrative example of how government experts sometimes wield their power to make these diagnoses. In over 140 cases, ${ }^{317}$ Dr. Grigson (often without ever having examined the defendant) testified to the effect that "the defendant 'has a severe antisocial personality disorder and is extremely dan-

312 Roper v. Simmons, 543 U.S. 551, 573 (2005).

313 See Blume \& Voisin, supra note 160, at 69 ("[T]o many people, and most judges, [the diagnosis of APD] means that the defendant is little more than a remorseless sociopath.").

314 See Abbott, supra note 176, at 296 (observing that no jurisdiction accepts diagnoses of psychopathy as basis for diminished capacity).

315 Cunningham \& Reidy, supra note 159, at 333; see also Blume \& Voisin, supra note 160 , at 69 (calling APD diagnosis "the kiss of death").

316 For example, the APA brief in Roper further underscores both the value of an APD or psychopathy diagnosis to prosecutors seeking the death penalty and the risk of misdiagnoses. The APA brief argued that there was an unacceptably high risk that teenagers would be misdiagnosed with APD or psychopathy and wrongly sentenced to death as a result. APA Brief, supra note 159, at 20 . It asserted that adolescents' dynamic and unstable personalities render it impossible to accurately diagnose APD or psychopathy at that stage of development. Id. at 19-22; see also id. at 9-12 (describing changes in adolescent brain prior to maturity). The risk that juries might erroneously conclude that an adolescent capital defendant is a psychopath is compounded by the fact that many of the transitory antisocial personality traits of teenagers overlap with those of the psychopath, including "proneness to boredom, impulsivity, irresponsibility, failure to accept responsibility for one's actions, and unstable interpersonal relationships." Id. at 22. In the Roper majority opinion, Justice Kennedy reprised this view, finding that jurors should not be asked to determine whether a juvenile capital defendant's crime "reflects unfortunate yet transient immaturity" or "irreparable corruption." Roper, 543 U.S. at 573. Justice Kennedy noted further that he shared the APA's worry that adolescents might be misdiagnosed with APD and psychopathy. See id. (noting that DSM-IV forbids psychiatrists from diagnosing patients younger than eighteen with APD).

317 Thomas Regnier, Barefoot in Quicksand: The Future of "Future Dangerousness" Predictions in Death Penalty Sentencing in the World of Daubert and Kumho, 37 AKron L. REv. 469, 481 (2004). 
gerous and will commit future acts of violence." 318 In the seminal case of Barefoot v. Estelle, ${ }^{319}$ he testified with "reasonable psychiatric certainty" that Barefoot fell in the "most severe category" of sociopaths and that Barefoot would, with "one hundred percent and absolute" certainty, commit future criminal acts, constituting a continuing threat to society. 320 Prosecutors often reprise these arguments directly or raise them in response to mitigation claims of nondangerousness (in those few jurisdictions that prohibit the prediction of dangerousness in the prosecution's aggravation case-inchief). ${ }^{321}$

Studies have shown that capital juries often regard evidence of future dangerousness as the most important aggravating factor in their sentencing calculus. Indeed, two commentators have noted that "Future dangerousness takes precedence in jury deliberations over any mitigating evidence, such as remorse, mental illness, intelligence, or drug/alcohol addiction, and any concern about the defendant's behavior in prison." 322 In fact, it has been observed that even in those jurisdictions that do not explicitly direct the capital jury to consider future dangerousness as an aggravating factor, jurors do so anyway. ${ }^{323}$

\section{The Marriage of Dr. Grigson and Lady Wootton}

As Paul Robinson has observed, within the context of sentencing, desert and dangerousness inevitably conflict as distributive criteria: "To advance one, the system must sacrifice the other. The irreconcilable differences reflect the fact that prevention and desert seek to

318 Blume \& Voisin, supra note 160, at 69 (quoting Satterwhite v. Texas, 486 U.S. 249, $253(1988)$ ). For a provocative profile of Grigson, see Ron Rosenbaum, Travels with Dr. Death, VANity FAIR, May 1990, at 140, as reprinted in NiNA Rivkind \& STEven F. Schatz, Cases and Materials on the Death Penalty 513 (2d ed. 2005).

319463 U.S. 880 (1983).

320 Id. at 919 (Blackmun, J., dissenting) (quoting from trial transcript); see also Barefoot v. State, 596 S.W.2d 875, 887-88 (Tex. Crim. App. 1980) (describing Grigson's testimony); Regnier, supra note 317, at 480-81 (same).

321 See Sevilla, supra note 311, at 252 n.19 (1999) (citing cases).

322 Beecher-Monas \& Garcia-Rill, supra note 295, at 1897; see also APA Brief, supra note 159, at 18-19 (noting empirical research showing extreme significance attached by juries to finding of "future dangerousness," including studies finding that " $85 \%$ of juries between 1974 and 1988 refusing to impose death penalty failed to find future dangerousness of defendant" and that "future dangerousness ranked second only to crime itself in attention given in jury's penalty phase deliberations, overshadowing evidence presented in mitigation").

323 See Beecher-Monas \& Garcia-Rill, supra note 295, at 1897-98 ("But whether or not future dangerousness ... is even mentioned by prosecutors or presented as evidence in the penalty phase of the case, it remains the major focus of the factfinders."); John H. Blume et al., Future Dangerousness in Capital Cases: Always "At Issue," 86 Cornell L. Rev. 397, 398-99 (2001) (finding future dangerousness is on minds of most capital jurors "no matter what the prosecution says or does not say"). 
achieve different goals. Incapacitation concerns itself with the future-avoiding future crimes. Desert concerns itself with the pastallocating punishment for past offenses." 324 The thrust-and-parry of this conflict is played out in dramatic fashion in the capital context. On the one hand, capital defendants introduce mitigating evidence to diminish their moral culpability, thus seeking a final refuge in the concept of retribution. On the other, the prosecution tenders evidence of future dangerousness, trying to stoke the consequentialist fears of the jury about violent acts that the defendant might commit if he is not permanently incapacitated by execution. In capital sentencing, pure consequentialism is the gravest threat to the defendant's life, while appeals to retributive justice are often his last, and best, hope.

The long-term aspiration of cognitive neuroscience decisively resolves this conflict between desert and crime control in favor of the latter by removing any consideration of diminished culpability. In so doing, the long-term scheme eliminates the last safe haven for a capital defendant whose sanity, capacity for the requisite mens rea, competence, and guilt are no longer at issue. Thus, in a final ironic twist, once retribution is replaced with a regime single-mindedly concerned with the prediction of crime and the incapacitation of criminals, the only possible use in capital sentencing of the neuroimaging research on the roots of criminal violence is to demonstrate the aggravating factor of future dangerousness.

Imagine for a moment how a jury concerned solely with avoiding future harms would regard an fMRI or PET image that purported to show the biological causes of a nonexcusing disposition to criminal violence. Likely, neuroimaging would radically amplify, in the minds of jurors, the aggravating effect of a diagnosis of APD or psychopathy. In a sentencing system that focused the jury's deliberation solely on the question of identifying and preventing crime, the work of the cognitive neuroscience project's architects would be transformed from a vehicle for seeking mercy into a tool that counsels the imposition of death.

It is only through the lens of just deserts that such evidence could possibly be regarded as mitigating. This conclusion is bolstered by capital defense experts who have observed that "Evidence of neurological impairment .... can be devastatingly damaging to the case for life. In presenting such evidence to a jury, counsel must be careful to avoid creating the impression that the defendant is 'damaged goods'

324 Paul H. Robinson, Punishing Dangerousness: Cloaking Preventive Detention as Criminal Justice, 114 HaRv. L. Rev. 1429, 1441 (2001). 
and beyond repair." 325 In the regime contemplated by the long-term aspiration-where claims of diminished culpability are untenablethis is the only permissible inference that jurors can draw. Arguing for compassion or leniency in such a system would be as nonsensical as seeking mercy for a dangerously defective car on its way to the junkyard to be crushed into scrap metal. Reconciliation and forgiveness are not useful concepts as applied to soulless cars; they are only intelligible as applied to sinners.

The grave implications of the long-term aspiration for capital sentencing come into even sharper relief when one considers the role that retributive justice has played in modern death penalty jurisprudence. Contrary to the intuitions of the project's architects, retribution has served as a crucial limiting principle on capital sentencing. The Supreme Court itself has referred to a "narrowing jurisprudence" of just deserts, ${ }^{326}$ which limits the ultimate punishment to "a narrow category of the most serious crimes" and defendants "whose extreme culpability makes them "the most deserving of execution." 327 In the name of retributive justice, the Court has barred the execution of mentally retarded defendants, ${ }^{328}$ defendants who were under the age of eighteen when their offense was committed, ${ }^{329}$ rapists, ${ }^{330}$ and defendants convicted of felony murder who did not actually kill or attempt to kill the victim. ${ }^{331}$ In each instance, the Court ruled that such defendants were not eligible for the death penalty because such punishment would be categorically disproportionate to their personal culpability. ${ }^{332}$ These same results could not have been reached if deterrence were the sole animating principle guiding the Court: general deterrence-i.e., whether the death penalty for a specific offense or a specific class of offenders will reduce crime overall-may be a contested issue. However, specific deterrence is always advanced by

\footnotetext{
325 Burt, supra note 288.

326 Atkins v. Virginia, 536 U.S. 304, 319 (2002).

327 Roper v. Simmons, 543 U.S. 551, 568 (2005) (quoting id.).

328 Atkins, 536 U.S. at 321 ("We are not persuaded that the execution of mentally retarded criminals will measurably advance ... the retributive purpose of the death penalty.").

329 Roper, 543 U.S. at 571 ("Retribution is not proportional if the law's most severe penalty is imposed on one whose culpability or blameworthiness is diminished, to a substantial degree, by reason of youth and immaturity.").

330 Coker v. Georgia, 433 U.S. 584, 592 (1977) ("We have concluded that a sentence of death is grossly disproportionate and excessive punishment for the crime of rape and is therefore forbidden by the Eighth Amendment as cruel and unusual punishment.").

331 Enmund v. Florida, 458 U.S. 782, 801 (1982) ("Putting Enmund to death to avenge two killings that he did not commit and had no intention of committing or causing does not measurably contribute to the retributive end of ensuring that the criminal gets his just deserts.").
}

332 See supra notes $326-30$ and accompanying text. 
the execution of a defendant, since execution guarantees that the same defendant will not cause future harm.

One might be tempted to think that without the engine of retribution, the political will to continue a regime of capital punishment will wither away. In fact, the average voter's desire for retribution has been blamed for the continued existence of capital punishment in the United States. ${ }^{333}$ But a review of recent political rhetoric on the death penalty contradicts this conclusion, suggesting that politicians prefer to couch their public arguments in terms of deterrence. For example, in one of the presidential debates of the 2000 election, Vice President Al Gore and Governor George W. Bush agreed that the only reason to support the death penalty was for its deterrent effects:

MODERATOR: Do both of you believe the death penalty actually deters crime? ...

BUSH: I do. It's the only reason to be for it. . . I don't think you should support the death penalty to seek revenge. I don't think that's right. I think the reason to support the death penalty is because it saves other people's lives.

GORE: I think it is a deterrent. I know that's a controversial view, but I do believe it's a deterrent. ${ }^{334}$

More recently, in an article describing the recent efforts on the part of various states to expand the death penalty to a wider array of offenses, every politician quoted cited deterrence as the sole motivation for the initiatives. ${ }^{335}$ It has further been observed that empirical studies purporting to show the deterrent effect of the death penalty have had a profound impact on the Supreme Court and the lay public by casting the death penalty as a life-saving institution. ${ }^{336}$ Finally, and perhaps most powerfully, the importance of deterrence is apparent from the aforementioned social science evidence, which shows that the aggravating factor of "future dangerousness" is the second-most decisive consideration (next to the fact of the underlying crime itself)

333 See Kirchmeier, supra note 279, at 640 (describing opinion of Professor James Whitman that ordinary voters are incapable of " the kind of routinized, sober, and merciful approach to punishment that is the stuff of the daily work of punishment professionals'" (quoting James Q. Whitman, Harsh Justice: Criminal Punishment and the Widening Divide Between America and Europe 55 (2003))).

334 The Third Gore-Bush Presidential Debate (Oct. 17, 2000), http://www.debates.org/ pages/trans2000c.html (emphasis added).

335 Emily Bazar, Wider Death Penalty Sought; At Least Six States Buck U.S. Trend, USA TODAY, Feb. 7, 2007, at A1.

336 See generally Jeffrey Fagan, Death and Deterrence Redux: Science, Law and Causal Reasoning on Capital Punishment, 4 OHIO ST. J. CRIM. L. 255, 257-61 (2006) (describing and critiquing original studies and "new wave" of dozen or more studies seeking to defend death penalty on deterrence grounds). 
for jurors contemplating the imposition of a death sentence. ${ }^{337}$ Thus, in actual deliberations, it is nearly certain that jurors privilege the question of deterrence above almost all other factors.

In fact, the widely shared intuition that seems to be motivating the long-term aspiration-namely, that retributive justice is the primary source of the brutality and harshness of the modern American criminal justice system ${ }^{338}$ - may generally be misguided. Many features of the criminal justice system that are frequently criticized as draconian and inhumane are, in fact, motivated by a purely consequentialist crime-control rationale. Such measures include laws that authorize life sentences for recidivists (e.g., "three strikes" laws), laws that reduce the age at which offenders can be tried as adults, laws that punish gang membership, laws that require the registration of sex offenders, laws that dramatically increase sentences by virtue of past history, and, most paradigmatically, laws that provide for the involuntary civil commitment of sexual offenders who show difficulty controlling their behavior. 339 These laws are the progeny of the principle animating the long-term aspiration, and some are worrisome examples of its possible implications.

Paul Robinson has offered a provocative genealogy for such laws that provides further grounds for caution. He makes a powerful argument that abandoning retributive justice in favor of consequentialist values of rehabilitation laid the groundwork for the draconian measures described above. According to Robinson's account, once "the limited ability of social and medical science to rehabilitate offenders became clear," reformers tried to salvage what was left of the consequentialist project by turning to incapacitation as the principle means of avoiding future crimes. ${ }^{340} \mathrm{He}$ concludes that "the harshness of the

337 See supra notes 322-23 and accompanying text.

338 See, e.g., Dan Markel, State, Be Not Proud: A Retributivist Defense of the Commutation of Death Row and the Abolition of the Death Penalty, 40 HARV. C.R.-C.L. L. REv. 407, 410-13 (2005) ("Countless cases in the Supreme Court equate retributivism with revenge or the desire to make criminals suffer or both. . . . [V]arious commentators reflexively embrace this view . . . ."); Mitchell N. Berman, Punishment and Justification 2-3, 3 n.5 (Dec. 15, 2006) (unpublished manuscript), available at http://ssrn.com/abstract $=956610$ ("Retributivists are said to be unable to make clear either why wrongdoers deserve to suffer or why it is permissible for a state institution to inflict suffering even if deserved. They are also deplored as savage or barbaric."). For a defense of retribution as the "only genuine and justified form of punishment" that rejects the notion that it is synonymous with vengeance and argues that retribution is a mechanism for restoring equality between wrongdoers and law-abiding citizens, see John Finnis, Retribution: Punishment's Formative Aim, 44 AM. J. Juris. 91, 102 (1999).

339 See Robinson, supra note 324, at 1429-31 \& nn.2-7 (citing statutes and legislative history making clear that all such laws are primarily oriented towards prediction and control of future crime).

340 Id. at 1449. 
current system may be attributed in largest part to the move to rehabilitation, incapacitation, and deterrence, which disconnected criminal punishment from the constraint of just desert."341

H.L.A. Hart's critique of Lady Wootton's project offers a similar cautionary note for the long-term aspiration. Hart himself was deeply skeptical about retribution as a general justifying aim of punishment, but he nevertheless recognized its importance as a limiting distributive principle on Wootton's purely forward-looking consequentialist concerns. ${ }^{342}$ As Hart recognized, a criminal justice system that is both single-mindedly committed to the prediction and prevention of antisocial behavior and self-consciously unconcerned with the mitigating effects of personal blameworthiness (or lack thereof) creates powerful incentives for the government to engage in highly intrusive behavior. ${ }^{343}$

Paul Robinson points to the possibility that "if incapacitation of the dangerous were the only distributive principle, there would be little reason to wait until an offense were committed to impose criminal liability and sanctions; it would be more effective to screen the general population and 'convict' those found dangerous and in need of incapacitation." 344 Indeed, the short-term project-using cognitive neuroscience to identify the roots of criminal violence-may someday create novel and powerful opportunities to interfere with individual liberty. Herbert Packer's words seem eerily prescient in light of this possibility:

[A] purely preventive view, reinforced as that view is today by a scientific and deterministic attitude toward the possibilities for controlling human conduct, carries the danger that single-minded pursuit of the goal of crime prevention will slight and in the end defeat the ultimate goal of law in a free society, which is to liberate rather than to restrain. ...

... The more confidently we can predict behavior and the more subtly we can control it, the more powerful will be the temptation to relax the constraints that inhibit us at present from aggressively

341 Robinson, Limiting Retributivism, supra note 281, at 14.

342 See Hart, supra note 267 , at $1328-29$ (arguing that retribution is consistent with, and curtails potential unfairness of, Wootton's deterrence theory).

343 See HART, supra note 1, at 181-82 ("Whereas a system from which responsibility was eliminated ... would leave each individual not only less able to exclude the future interference by the law with his life, but also less able to foresee the times of the law's interference."); Hart, supra note 267, at 1330 ("If the doctrine of mens rea was no longer a necessary condition for convictions the occasions for official interferences in our lives would be vastly increased.").

344 Robinson, supra note 324 , at 1439-40. 
intervening in the lives of individuals in the name of crime prevention. ${ }^{345}$

Questions of whether a given individual poses a continuing threat to society are central to the criminal justice system. In addition to capital sentencing, fact finders are charged with making such determinations in the context of noncapital sentencing, civil commitment hearings, parole and probation hearings, pretrial detention, and involuntary civil commitment of sexual offenders. ${ }^{346}$ Regardless of neuroimaging's capacity or incapacity to predict criminal behavior reliably, there is already a powerful demand for the use of such techniques in crime control. Moreover, far more controversial methods for predicting future social harms have already been accepted by the Supreme Court in the capital sentencing context. This problem would be dramatically aggravated by adopting a criminal framework that places an even higher premium on the prediction and prevention of violence than the present one does.

\section{Objections and Responses}

One can anticipate the rejoinders that the architects of the cognitive neuroscience project might raise in response to the above critique. First, they might argue that the short-term theory of mitigation does not depend on just deserts, but rather it depends on the notion that the rationale of deterrence underlying the death penalty is inapplicable to defendants with brain defects or personality disorders. Next, they might retort that this critique fails to recognize that the aim of the long-term aspiration is not incapacitation, but rehabilitation. Finally, they might argue that the prediction of a draconian, inhumane, and invasive system of criminal law will not come to pass as a result of their efforts because society simply would not accept it; the revulsion and fear that citizens would feel toward such a system would not be tolerated. Each of these arguments will be taken in turn.

Cognitive neuroscientists may defend the use of neuroimaging evidence for mitigation by attempting to ground the concept of mitigation in the consequentialist value of deterrence rather than in just deserts. They likely would argue that capital punishment cannot deter individuals with certain types of brain abnormalities, and so presenting evidence of these abnormalities merely shows that there is no deterrence rationale for imposing a death sentence on such individ-

345 Herbert L. Packer, The Limits of the Criminal Sanction 66 (1968).

346 See FAIGMAN ET AL., supra note 305 , at 78 (discussing wide variety of contexts in which expert testimony concerning future behavior is relevant); Slobogin, supra note 298, at 1-2 (listing ways in which "[d]angerousness determinations permeate the government's implementation of its police power"). 
uals. In fact, Greene and Cohen take this very approach in their arguments in favor of retaining certain excuse defenses (such as diminished capacity, infancy, insanity, and duress) because there is no deterrence value in punishing people in circumstances where such excuses apply. ${ }^{347}$ This argument is essentially the same as Bentham's response to Blackstone regarding the permissible excusing conditions for criminal acts. ${ }^{348}$ Blackstone argued that the excusing defenses "may be reduced to this single consideration: the want or defect of will," and that "a vitious will" is a prerequisite to criminal liability. ${ }^{349}$ Bentham retorted that the excusing defenses were not rooted in this notion of blameworthiness and just deserts but, rather, were a recognition that punishing "the mad, the infant child or those who break the law unintentionally or under duress or even under 'necessity' must be inefficacious" because such offenders are inherently undeterrable. ${ }^{350}$

This argument fails to provide an alternative, consequentialist justification for the short-term aspiration's theory of mitigation for at least two reasons. First, the argument is, as H.L.A. Hart noted, a "spectacular non sequitur." 351 It purports to claim that offenders with a brain defect or personality disorder are not deterrable by the threat of the death penalty. It is possible that, as Hart pointed out, the infliction of the punishment might nevertheless "secure a higher measure of conformity to law on the part of normal persons than is secured by the admission of excusing conditions," thus increasing the overall amount of crime control for society. ${ }^{352}$ In addition, it is obvious that a death sentence will be effective as a specific deterrent on the convicted offender.

347 Greene \& Cohen, supra note 57, at 1783.

348 See HART, supra note 1, at 18-19 \& nn.21-22 (citing JeREMY BENTHAM, INTRODUCtion to the Principles of Morals and Legislation ch. 13, II 9 \& n.2 (Prometheus Books 1988) (1781); William Blackstone, 4 Commentaries *20-21) (discussing Bentham's reply to Blackstone on excusing conditions for criminal acts).

349 Id . at 18 (citing BLACKSTONE, supra note 348 , at $* 20-21$ ).

350 Id at 19 (citing BENTHAM, supra note 348 , at ch. 13 , II 9,11 ).

351 Id.

352 Id. One is reminded by this argument of the hypothetical conversation between Oliver Wendell Holmes and the condemned man who claims he could not help himself in committing a capital offense:

If I were having a philosophical talk with a man I was going to have hanged (or electrocuted) I should say, I don't doubt that your act was inevitable for you but to make it more avoidable by others we propose to sacrifice you to the common good. You may regard yourself as a soldier dying for your country if you like. But the law must keep its promises.

Letter from Oliver Wendell Holmes to Harold J. Laski (Dec. 17, 1925), in 1 HolmesLaski Letters: The Correspondence of Mr. Justice Holmes and Harold J. Laski 806 (Mark DeWolfe Howe ed., 1953). 
But an attempt to ground the short-term aspiration's theory of mitigation in this way fails for a more fundamental reason: the law of capital sentencing does not presently accept the proposition that defendants who are afflicted by the kinds of conditions that cognitive neuroscientists invoke in mitigation (e.g., hypoactivity of the prefrontal lobe, APD, or psychopathy) are undeterrable. ${ }^{353}$ Sentencing law does not accept (nor do the mitigation experts argue) that these conditions preclude appreciation of one's actions, conformity with the law, or formation of the requisite mens rea. If the law did accept this claim, such defendants would prevail at the guilt stage of their trials and would not face sentencing. Bentham and Blackstone's debate, after all, was about using excuse defenses to guilt; by definition, mitigation claims raised at the sentencing phase of a capital trial are moot for that purpose.

It does not seem possible, under present capital sentencing categories, to characterize the theory of mitigation invoked by cognitive neuroscientists under the short-term aspiration as anything other than an argument for diminished culpability rooted in the overarching distributive principle of just deserts. That being so, the long-term and short-term aspirations, as argued above, remain at loggerheads.

Next, the defenders of the cognitive neuroscience project might argue that the project is aimed at rehabilitation and not mere incapacitation-that is, it aspires to bring about a regime of "therapeutic justice." This argument also fails to rescue the project, both for principled and prudential reasons. First, it is not clear how a regime devoted solely to avoiding future harms to society compels the pursuit of rehabilitation for offenders, except perhaps on economic efficiency grounds. It cannot be because neurologically defective defendants deserve a punishment less than death due to their diminished culpability, since this would be an appeal to retribution. Moreover, for offenders with the neurological conditions associated with a predisposition to criminal violence, rehabilitation may very well prove impossible. Future prospects of rehabilitation for those laboring under one such condition-psychopathy-seem quite bleak, according to the conventional wisdom of the mental health community. ${ }^{354}$ (Indeed,

353 For a thoughtful critique of the present state of the law proposing and arguing for a way in which criminal law's "voluntary act" requirement can take into account developments in the science of consciousness, see Deborah W. Denno, Crime and Consciousness: Science and Involuntary Acts, 87 MINN. L. REv. 269, 274-75 (2002). For a critique arguing for the development of "neurojurisprudence," allowing for a defense that the defendant suffered from frontal lobe damage causing a lack of behaviorial control, see Redding, supra note 208 , at 53 .

354 See supra note 159 and accompanying text. 
therein lies its persuasive force as an aggravating factor, as Justice Kennedy observed in Roper. $)^{355}$ As Robinson has observed, once just deserts has been eliminated as a legitimate distributive principle of punishment and therapies for criminal misconduct have proven unavailing, societies often turn to incapacitation as the sole animating value of the criminal law. ${ }^{356}$

Finally, cognitive neuroscientists might claim that the draconian capital sentencing regime predicted above will not come to pass as a result of the cognitive neuroscience project because the public would not stand for it. Put another way, they might argue that such a regime, even if it were the logical outgrowth of widely held beliefs, would generate too much social disapproval to be justified under consequentialist principles. Greene and Cohen make this argument in response to the possible claim that their vision for the criminal law would produce massive overpunishing. They argue, by way of example, that society would not tolerate the inhumanity of executing parking-law violators. $^{357}$

There are two powerful responses to this argument. First, this Article is a critique of the cognitive neuroscience project for capital sentencing, not for the criminal law more generally. Capital defendants are arguably the most hated and feared members of society. It is unlikely that there would be substantial social discontent with a regime that was geared toward the permanent incapacitation of such individuals. For better or worse, there is not widespread opposition to the execution of defendants who are factually and legally guilty, sane, competent, and with the requisite mens rea, yet who present neuroimaging evidence suggesting that they have a neurological condition or personality disorder that inclines them (if not irresistibly) towards murderous acts. The continued successful invocation of APD and psychopathy as aggravating factors by prosecutors, and the substantial number of defendants claiming frontal lobe dysfunction who have nevertheless been sentenced to death, illustrates that our society is (again, for better or worse) quite comfortable executing such individuals. ${ }^{358}$

Second, even if there were widespread societal discomfort with executing those whose brains make them incorrigibly violent, this would not prevent such executions under Greene and Cohen's framework. Rather, this anxiety could be explained away as a function of

355 See Roper v. Simmons, 543 U.S. 551, 573 (2005) (referring implicitly to APD and psychopathy (or sociopathy) as "irreparable corruption").

356 Robinson, supra note 324 , at 1447-49.

357 Greene \& Cohen, supra note 57, at 1783.

358 See supra note 215. 
the irrational dichotomy between "him" and "his brain," that the cognitive neuroscience project deplores. As Greene and Cohen argue, using an appealing fiction (such as free will) may be acceptable for decisions relating to small things, just as having faith in Euclid and Newton is safe when negotiating the aisles of the grocery store. ${ }^{359}$ But in matters as important as capital sentencing, Greene and Cohen would argue that we must have the courage to abandon such fictions and embrace the truths of cognitive neuroscience-just as we must turn to Lobachevsky and Einstein when we want to launch a rocket into space. ${ }^{360}$

\section{CONCLUSION}

This Article has essayed to identify, articulate, and take seriously what appears to be an emerging project within the cognitive neuroscience community to reform capital sentencing. It concludes that, while the goals of making capital sentencing more rational and humane are laudable, the project itself is ill-conceived. Its impact likely will be the opposite of what it seeks because the project's shortand long-term goals are intractably opposed to one another. Its shortterm aspiration depends on the very doctrine of just deserts that its long-term vision seeks to dismantle. The long-term aspiration seeks to bring about a criminal justice regime that is oriented solely towards the consequentialist goal of avoiding future harms. In such a regime, the singular focus of the criminal law becomes the prediction and prevention of criminal acts. But we know from painful experience that the extant mechanisms in the capital sentencing regime that are calibrated to do this sort of work-most notably, the aggravating factor of future dangerousness-are no friend to the capital defendant. In fact, they are often the gravest threat to his life. In the context of death penalty sentencing, defendants often find that their only refuge is an appeal for leniency based on a claim of diminished personal responsibility, a claim that is founded squarely on the retributive principle that the long-term approach repudiates.

What can be done in the face of this difficulty? Is it possible or desirable to salvage the cognitive neuroscience project in a way that will preserve its humanitarian ends? Or is the reductive materialist account of human personhood and human agency posited by cognitive neuroscience-and, indeed, by modern science more generally-

359 Greene \& Cohen, supra note 57, at 1784.

360 See id. ("[There] may be special situations, analogous to those routinely encountered by 'rocket scientists', in which the counter-intuitive truth that we legitimately ignore most of the time can and should be acknowledged."). 
incommensurable with the account on which the criminal law is premised? These are questions for another day. The aim of this Article has been to lay the groundwork for such future discussions by exploring the implications and unintended consequences of the project as presently conceived. Understanding where an argument leads in principle and practice is a necessary precursor to appraising its wisdom-an appraisal that is particularly essential when human lives hang in the balance. 